Illinois State University

ISU ReD: Research and eData

Theses and Dissertations

3-11-2019

\title{
Navigating For The Adult Student: Ways To Help Adult Students Transfer Successfully From Community Colleges To Universities
}

Bethany M. Craig

Illinois State University, bethanymcraig@gmail.com

Follow this and additional works at: https://ir.library.illinoisstate.edu/etd

Part of the Adult and Continuing Education Administration Commons, Adult and Continuing Education and Teaching Commons, Higher Education Administration Commons, and the Higher Education and Teaching Commons

\section{Recommended Citation}

Craig, Bethany M., "Navigating For The Adult Student: Ways To Help Adult Students Transfer Successfully From Community Colleges To Universities" (2019). Theses and Dissertations. 1106.

https://ir.library.illinoisstate.edu/etd/1106

This Dissertation is brought to you for free and open access by ISU ReD: Research and eData. It has been accepted for inclusion in Theses and Dissertations by an authorized administrator of ISU ReD: Research and eData. For more information, please contact ISUReD@ilstu.edu. 


\title{
NAVIGATING FOR THE ADULT STUDENT: WAYS TO HELP ADULT STUDENTS TRANSFER
}

\section{SUCCESSFULLY FROM COMMUNITY COLLEGES TO UNIVERSITIES}

\author{
Bethany M. Craig
}

\section{Pages}

Despite the research that exists about transfer students, there is limited literature on the services that colleges and universities provide to adult students who transfer from community college to university. The number of adult students who participate in postsecondary education continues to grow. The purpose for this mixed method exploratory study was to gather data through both telephone conversations and a survey of transfer coordinators at Illinois institutions of higher education, including community colleges, public four-year institutions, and private, nonprofit four-year institutions. The study sought to understand what transfer coordinators perceive their colleges and universities are doing to help adult students transfer from community colleges to universities, what transfer coordinators perceive their colleges should be doing to help adult students transfer, and to determine whether there is a gap between what coordinators perceive that their colleges are doing to help adult students transfer from community colleges to universities and what they perceive that their colleges should be doing.

Gaps between what coordinators perceive their colleges are doing to help adult students transfer from community colleges to universities and what they perceive their colleges should be doing resulted in important implications that emerged from the findings. Those 
implications include: (a) college and universities should provide resources and support for faculty to help them understand how teaching adult students differs from teaching traditional students; (b) colleges and universities should focus on providing course offerings at convenient times and places as well as bachelor's degree completion programs for place-bound community college graduates; (c) institutions should work with other colleges and universities around the state to collaborate and improve services for adult students; (d) colleges and universities may want to consider ways to make adult students feel connected and as welcome as traditional students; (e) institutions may want to consider providing support services offered at convenient times for adult students. In addition to these recommendations, the study also suggests areas for further research.

KEYWORDS: adult students, higher education, transfer students 
NAVIGATING FOR THE ADULT STUDENT: WAYS TO HELP ADULT STUDENTS TRANSFER

SUCCESSFULLY FROM COMMUNITY COLLEGES TO UNIVERSITIES

BETHANY M. CRAIG

A Dissertation Submitted in Partial

Fulfillment of the Requirements

for the Degree of

DOCTOR OF PHILOSOPHY

Department of Educational Administration and Foundations

ILLINOIS STATE UNIVERSITY

2019 
(C) 2019 Bethany M. Craig 
NAVIGATING FOR THE ADULT STUDENT: WAYS TO HELP ADULT STUDENTS TRANSFER SUCCESSFULLY FROM COMMUNITY COLLEGES TO UNIVERSITIES

BETHANY M. CRAIG

COMMITTEE MEMBERS:

James Palmer, Chair

Lydia Kyei-Blankson

Zeng Lin

Mohamed Nur-Awaleh 


\section{ACKNOWLEDGMENTS}

This has been a long and winding road and I must thank my husband, John, for his unending patience and support. Also, thanks and much love are due to my daughters, Gabrielle and Josephine, who have had to give up time with their Mommy while she spent many hours on the computer.

I am grateful to Dr. Jim Palmer for his support and guidance as my chair. Dr. Lydia KyeiBlankson, Dr. Mohamed Nur-Awaleh and Dr. Zeng Lin provided useful advice and good questions that improved the quality of the proposal leading up to this final creation.

B.M.C. 
$\begin{array}{ll}\text { The Research Problem } & 1\end{array}$

$\begin{array}{ll}\text { Methodology } & 7\end{array}$

$\begin{array}{ll}\text { Definitions } & 9\end{array}$

Significance of the Study $\quad 9$

$\begin{array}{ll}\text { Delimitations } & 12\end{array}$

CHAPTER II: REVIEW OF THE LITERATURE 13

$\begin{array}{ll}\text { Adult Learners in Higher Education } & 13\end{array}$

$\begin{array}{ll}\text { Adult Learners Defined } & 14\end{array}$

How Adult and Younger Students Experience College 15

$\begin{array}{ll}\text { Implications for Practice } & 18\end{array}$

$\begin{array}{ll}\text { Conceptual Framework } & 21\end{array}$

Helping Students Transfer: Four Dimensions 26

$\begin{array}{ll}\text { Bureaucratic Dimension } & 26\end{array}$

Social Dimension $\quad 29$

Curricular Dimension $\quad 31$

Student Services Dimension 34

$\begin{array}{ll}\text { Conclusion } & 36\end{array}$ 
$\begin{array}{ll}\text { Research Design } & 39\end{array}$

$\begin{array}{ll}\text { Instrumentation and Data Collection } & 40\end{array}$

Stage One: Developing the Questionnaires 42

$\begin{array}{ll}\text { Recruitment of Participants } & 42\end{array}$

First Round of Conversations $\quad 44$

$\begin{array}{lr}\text { Second Round of Conversations } & 50\end{array}$

Stage Two: Data Collection and Analysis 53

Stage Three: Third Round Conversation with Transfer Coordinators 54

CHAPTER IV: ANALYSIS OF DATA AND RESULTS

$\begin{array}{ll}\text { Responses by Sector } & 60\end{array}$

$\begin{array}{ll}\text { Community Colleges } & 60\end{array}$

$\begin{array}{ll}\text { Four-Year Institution Survey Results } & 76\end{array}$

Final Transfer Coordinator Conversations 95

What Survey Findings Suggest about Practice 95

$\begin{array}{ll}\text { Specific, Actionable Advice } & 96\end{array}$

$\begin{array}{ll}\text { Conclusion } & 96\end{array}$

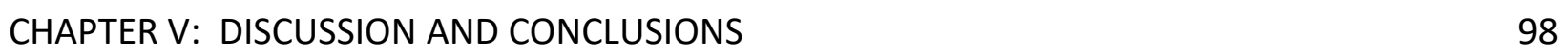

$\begin{array}{ll}\text { The Thesis of the Study } & 100\end{array}$

$\begin{array}{ll}\text { Discussion - Points of Commonality and Divergence } & 100\end{array}$

$\begin{array}{ll}\text { Articulation and Credit Transfer } & 101\end{array}$

$\begin{array}{ll}\text { Curriculum and Instruction } & 101\end{array}$ 
Implications for Practice

Implication 1

Implications 2 and 3

Implication 4

APPENDIX B: REVISED SURVEY INSTRUMENTS THAT INCORPORATE FOCUS GROUP

APPENDIX C: LETTERS AND STUDY REFERENCE GUIDES FOR FOUR-YEAR INSTITUTION AND 


\section{TABLES}

Table

Page

1. Percentage of Adult Students Who View Themselves As Employees Versus Students Who Are Employed

2. Survey Response Rate by Type of Institution

3. Contextual Information Reported On Community College Survey and Four-Year Institution Survey

4. Mean and Distribution of Responses for "Does Reflect" and "Should Reflect" Statement Pairs, By Topic for Community College Respondents

5. Community College Questionnaire Items Rank Ordered by The Difference Between What Is and What Should be Done for Adult Transfer Students

6. Mean and Distribution of Responses for "Does Reflect" and "Should Reflect" Statement Pairs, by Topic for Four-year College Respondents

7. Four-Year Institution Questionnaire Items Rank Ordered by The Difference Between What Is and Should Be Done for Adult Transfer Students 


\section{CHAPTER I: BACKGROUND AND STATEMENT OF THE PROBLEM}

\section{The Research Problem}

Services for transfer students exist in different formats at most colleges and universities.

Some institutions have robust, comprehensive services offered specifically for transfer students. Others have basic services for students that are general in nature and may or may not consider transfer students specifically. These services are provided to support the educational mission of a particular institution. There is literature devoted to college transfer in general that discusses various issues related to policies, practices and outcomes (Dougherty, 2009). Authors have written about the transfer student adjustment process for traditional aged students (Laanan, 2001) which includes transfer behavior, post-transfer academic performance, and the transfer adjustment process. They have also written about the ways that institutions can provide services to students who are interested in transferring, such as transfer student centers (Collins, Navarro \& Stinard, 2011; Zamani, 2001). In addition, research has examined the implementation of transfer associate degrees in different states (Compton, Tafel, Law, \& Gustafson, 2001; Cope, 2012; Patton \& Pilati, 2012; Sherman \& Andreas, 2012).

There is limited literature on the services that colleges and universities provide to adult students who transfer from community college to university. In general, research on adult transfer students can be divided into four schools of inquiry. Those schools of inquiry include social and academic engagement of adult learners, credit transfer, vertical transfer and the variety of educational services being offered by colleges and universities.

Social and academic engagement of adult transfer students can be seen in the writings of Anderson (2013) regarding the influence of student engagement on adult learners, 
specifically on community college students and their intentions to transfer; as well as with Zhang, Lui and Hagedorn (2013) who studied the academic, social and transfer experiences of adult students at a large research university. Along this same theme, Lester, Leonard and Mathias (2013), studied ways transfer students perceived their social and academic engagement.

Credit transfer is a second school of inquiry. Pegg and DiPaolo (2013) examined how credit transfer was used by adult students to support their re-engagement (unfinished business) with their college studies. Emory, Raymond, Lee and Twohy (2016) also looked at credit transfer, but from a different viewpoint. This viewpoint was from the remedial coursework (or basic education standpoint) and how a specific academic program (entitled Integrated Basic Education and Skills Training or I-BEST) was designed to allow upper-level basic education students to directly enter academic courses required by college transfer degrees. A third way of looking at credit transfer was completed by Cardozier (1993) who was a founding vice president for academic affairs at a higher education institution that was created only as an upper-division and graduate institution for community college graduates. This institution was the University of Texas Permian Basin. The intent of this university was to serve part-time students who were transferring from community colleges since there was no university in that geographical area in Odessa, Texas.

A third school of inquiry on research of adult transfer students is vertical transfer. Vertical transfer can be defined as the process of transferring from a two-year community college to a four-year institution; sometimes students earn their associate's degrees and sometimes they do not (Taylor \& Jain, 2017). Vertical transfer has been studied by Yavitz 
(2017) who examined student records of adult community college students to determine the impact of certain academic momentum variables on the likelihood of adult community college students "achieving vertical transfer or post-transfer baccalaureate degree completion" (p. 3). She found that adult students who chose any type of degree or transfer program have higher odds of transfer, and adult first time in college students have lower odds of transferring and completing a degree than returning students. While breaks in college enrollment, reduced credit accumulation during the first year of college and a decrease in enrollment of courses have been shown to hinder traditional aged students from transfer and baccalaureate completion, they did not have negative effects on adult students in this study. The results of this study suggest that these academic momentum variables may impact adult students' possibility of success for transferring, but the effects differ between adult students and traditional aged students.

Schwehm (2017) also studied vertical transfer to identify if demographic characteristics and community college experiences influence the adjustment process of adult vertical transfer students. The study collected data on adult vertical transfer student demographic information and student community college experiences. The data was examined in relation to academic self-efficacy, university GPA and sense of belonging to the university. The study showed three influential variables. Those included the level of perceived classroom involvement at community colleges helped to predict academic self-efficacy at the university, the community college GPA was the most significant variable in predicting the university GPA and the level of classroom involvement at the community college was the most significant variable in predicting social adjustment at the university. 
A fourth school of inquiry is the variety of educational services being offered by colleges and universities. Those educational services include academic advising; more specifically, developmental advising. Developmental advising is the relationship where the academic advisor talks with the student to look at immediate academic goals in addition to long-term academic goals (Frost, 1991). This article discusses a variety of students, including both transfer students and adult students. Along with academic advising, Dougherty (2009) discussed the variety of educational services that community colleges offer for adult students. Cleary (2013) examined educational services by looking into the ways in which adult transfer students write within their jobs, their studies, in their communities and at home. In her work, she includes implications for teaching writing for adult students. Fox and Harvey (1994) looked at services that institutions could offer adult transfer students by using a competence-based focus. These findings focus on library resources and on community-based faculty and classrooms as essential services for colleges and universities to offer. Adult transfer student motivation was studied by Allen and Zhang (2016) to understand the experiences of students transferring from community college to the four-year institution. From this study, recommendations for educational services emerged, including ways that institutions can encourage interaction between older adult students and traditional students as well as restructuring campus involvement opportunities for adult learners.

The number of adult students who participate in postsecondary education continues to grow. This has been attributed to a greater awareness of the link between education and earnings, the adoption of new technologies that have made distance education more feasible, and the tendency of colleges and universities to seek out adult students as a way of increasing 
enrollments and making up for attenuated state funding (Ginsberg \& Wlodkowski, 2010). Data collected by the National Center for Education Statistics reveals that in 2016, 35\% of students at the nation's community colleges were 25 years of age and older (National Center for Education Statistics, 2016). As such, colleges and universities must take note of this trend and offer services to these adult students who often have plans to transfer to universities and pursue advanced degrees. Both two-year and four-year institutions should consider services that provide "financial, academic or social support for adult learners" (Dougherty, 2009, p. 57) and should work together to promote the transfer function for adult learners (Dougherty, 2009).

Although prior studies have provided important insights, researchers have yet to assess the extent to which community colleges and receiving universities are well-positioned to work with adult transfer students. Often, services are tailored to traditional students who have different needs than adult students. For example, traditional students are typically offered housing and dining hall services for their college experience as they often choose to live on campus in dorms or other housing options. Traditional students are also offered advising services that are geared specifically for them to take coursework during the daytime since they are often full-time students. But as indicated previously, the experiences of adult transfer students and the services that will help them transfer have not been researched at a depth like traditional students. These services for adult students are important, as state and college leaders realize that serving this population of students is "critical to the economy and in many cases, institutions' own financial health" (Blumenstyk, 2018, p. 1).

The purpose of this study is to elicit expert opinions from transfer coordinators on what colleges are and should be doing to help adult transfer students. Data for this study was 
gathered through a survey of transfer coordinators at Illinois institutions of higher education, including community colleges, public four-year institutions, and private, nonprofit four-year institutions. Transfer coordinators were selected as participants because they serve as a primary point of contact for transfer students as well as to facilitate articulation agreements, transfer pathways and serve as an advocate for transfer students (Illinois Articulation Initiative, 2019). Transfer coordinators are valuable resources in assisting students as they plan to transfer from the community college to the university. In Illinois, transfer coordinators are a vital link in assisting students with questions and concerns as they plan to transfer from the community college to the university.

The following research questions guided the study:

1. What do transfer coordinators perceive their colleges are doing to help adult students transfer from community colleges to universities?

2. What do transfer coordinators perceive their colleges should be doing to help adult students transfer?

3. Is there a gap between what coordinators perceive that their colleges are doing to help adult students transfer from community colleges to universities and what they perceive that their colleges should be doing?

This study did not seek to evaluate the success of transfer services for adult students, but only to examine transfer coordinator perceptions of what services tend to be provided, what services should be provided, and how actual practice may differ from desired practice. 


\section{Methodology}

This exploratory study involved a mixed methods approach by employing telephone discussions as well as a survey. Study data was collected through telephone discussions and surveys of Illinois transfer coordinators at community colleges, four-year public higher education institutions and four-year private higher education institutions.

Two questionnaires were used in the survey, one for transfer coordinators at community colleges and the other for the transfer coordinators at receiving four-year institutions. While each of the two questionnaires were similar, there were a few differences in questions between the community college survey and the four-year institution survey due to the nature of the differences in the types of higher education institutions. Both surveys included a list of statements about services that might be provided to help adult students negotiate the transfer process. Respondents were asked to rate the extent to which each statement reflects actual practice at their institutions and then the extent to which the statements reflected what the practice should be.

The study was completed in three stages.

- Stage one: Questionnaire development. Telephone conversations involving selected transfer coordinators were held to discuss the problems adult students face when transferring from community colleges to universities. The conversations also elicited the perceptions of what transfer coordinators believe colleges and universities can be doing to help adult students to transfer successfully. A second round of telephone conversations was held to review an initial draft of two questionnaires: one sent to the transfer coordinators at receiving four-year institutions, and the other sent to the 
transfer coordinators at community colleges (see Appendix A). These questionnaires were derived from both the literature as well as from key ideas emerging from the first round of telephone conversations. Suggestions made by participants were used to complete the final version of the questionnaires, which were submitted to the Institutional Review Board for approval prior to proceeding with the second stage of the study.

- Stage two: Administering the questionnaire. Transfer coordinators at Illinois two-year and four-year colleges were invited to complete the final versions of the questionnaires, which were administered online via Survey Monkey. The initial invitation was sent in a letter that provided the URL for the survey. The mailing was followed up with two email reminders. Contact information for the transfer coordinators can be found on the website of the Illinois Articulation Initiative (https://itransfer.org/transfercoordinators/transfercoorddirectory.php). The survey was anonymous; the researcher did not know which transfer coordinators responded.

- Stage three: Follow-up telephone conversations. Follow-up telephone conversations (in some cases group telephone conversations and in others individual telephone conversations), comprised of the same initial transfer coordinators, also convened and elicited perceptions of what the survey findings suggest about implications for practice. Survey responses were analyzed to answer the research questions this study sought to address. For each of the research questions, descriptive statistics (mean, median, mode and range) were used. For research question two, descriptive statistics were used to highlight or illustrate the gaps between actual and desired practices. 
It is important to note that the unit of analysis for this study was the sector (the three sectors are community colleges, four-year public institutions and four-year private institutions); not the individual institutions or the individual transfer coordinators participating in the focus group meetings and in the state-wide survey. The results of the study have implications for institutional work and services with students, not for the work of the individual transfer coordinators.

\section{Definitions}

Adult students, are, for the purposes of this study, 25 years of age or older.

Services (college services), are those opportunities for adult students (such as orientation and academic advising) that are specifically created and designed at community colleges and universities with the adult student in mind.

Transfer coordinator is a professional who works in higher education and serves as a primary point of contact as well as an advocate for transfer students. In addition, transfer coordinators facilitate articulation agreements and transfer pathways for students (Illinois Articulation Initiative, 2019).

\section{Significance of the Study}

Examining the services that transfer coordinators provide to adult students at community colleges and universities is important for three reasons. First, as far back as 1981, Cross noted that the United States "is becoming a nation of adults" (Cross, 1981, p. 3). The population is aging and thus the number of adult students continues to grow. Merriam, Caffarella and Baumgartner (2007) posit that "for the first time in our society, adults outnumber youth, there are more older adults, the population is better educated than ever 
before and there is more cultural and ethnic diversity" (p. 7). The United States Census Bureau (2018) has stated that by the year 2030, 78 million Americans will be people 65 years of age and older and only 76.4 million people will be under the age of 18 . This means that the need for postsecondary education opportunities for adults will likely increase.

Societal factors such as the aging population, the influx of immigrants, increased numbers of women entering and staying in the workplace, along with shifting technologies...have all contributed to escalated involvement in learning activities growing number of adults participating in learning activities (Hansman \& Mott, 2010, p.13).

Many of these adults will need college coursework to help them obtain and advance in their careers. These adults will rely on community colleges and universities to provide the education they need to be successful.

Second, student affairs professionals who work with transfer students will benefit from data that gauge the adequacy of the services they employ to help adult students negotiate the transfer process. Drawing on the perceptions of a key group of these professionals -- the transfer coordinators at Illinois colleges and universities - this study contrasted the services that tend to be offered at both community colleges and receiving four-year colleges with the services that-in the opinion of the transfer coordinators-should be offered. This picture of actual versus ideal practice can provide transfer staff with an important starting point for thinking about how their services might be improved. These improvements will be critically important to colleges as competition for students becomes more and more fierce. 
Third, helping adults negotiate the transfer process from community colleges to fouryear institutions will advance the goal of increasing the educational attainment of American citizens. President Donald Trump has allocated funding in the United States fiscal year 2018 budget to support adults without a high school diploma to become literate and able to obtain the knowledge and skills that are necessary to complete postsecondary education. This opportunity will increase literacy, workforce skills and economic self-sufficiency of adult citizens (United States Department of Education, 2018). There have also been persistent calls over the past decade to increase the percentage of the population that holds a postsecondary credential. Former President Barack Obama had also set a new educational goal for the country. That goal was that by the year 2020, America would have the highest amount of college graduates in the world (Obama Whitehouse Archives, 2018). In addition, the Lumina Foundation has set a goal of increasing the number of Americans who have a certificate, degree or high-quality credential to $60 \%$ by the year 2025 because they believe it is essential to meeting the nation's growing need for talent (Lumina Foundation, 2018). Lumina (2018) posits this is an urgent need, as our fast moving and complex economy is in dire need of skilled employees. Currently, "the United States lags behind its global competitors in postsecondary attainment. America currently ranks a disappointing eleventh [in the world] for global postsecondary attainment" (Lumina Foundation, 2018, p. 1). These initiatives are important and enhancing transfer opportunities for adults will play an important role in helping our country to meet educational goals. 


\section{Delimitations}

Transfer coordinators may not be the only people at a college or university who work with adult students. Some institutions may also have staff in academic departments who work with adult students. After all, many academic departments are creating new programs that are marketed specifically for adult students only and meet either online or in the evenings and on weekends when adult students can participate. For instance, the University of Illinois at Springfield offers online bachelor's degrees, graduate degrees, certification and licensure programs. A few examples of these programs are a Bachelor of Science in computer science, a Master of Arts in education and licensure as an education technology specialist (University of Illinois Springfield, 2018). The courses for these programs are offered online, in the evening, and during the weekends to fit the busy schedules of adult students (University of Illinois Springfield, 2018). In addition, some colleges and universities may have entire units (such as a School of Continuing Education or an outreach and extension office) that have the responsibility for providing adult students with degree programs, courses and services. Thus, although transfer coordinators are highly versed in transfer protocols and represent their institutions in statewide meetings concerning transfer policy, their perceptions capture only a portion of staff viewpoints on factors that contribute to the transfer success of adult students.

In conclusion, understanding what services colleges and universities provide for adult students who transfer from community college to university is an important topic. As the number of adult students in higher education continue to increase, finding ways to support these students may be important to the future of higher education institutions who wish to serve adult students. 


\section{CHAPTER II: REVIEW OF THE LITERATURE}

Students who transfer from community colleges to universities face many challenges. These students must learn to navigate two very different types of higher education institutions. Just as they learn the processes for the community college, they graduate and must transfer to a four-year institution where the processes can be very different. Since their life experiences and circumstances may be very different from younger, traditional students, adult transfer students require different approaches to help them succeed.

A review of the literature on student transfer from community colleges to four-year institutions suggests that efforts to help transfer students are categorized into four dimensions: the bureaucratic dimension, the social dimension, the curricular dimension, and the student services dimension. After a discussion of adult learners and how they differ from students in the traditional college-going age range, as well as an explanation of the conceptual framework used in this study, each dimension is described and implications for work with adult students transferring from community colleges to universities are discussed.

\section{Adult Learners in Higher Education}

Adult students are different from younger students in many ways. In particular, adult learners bring a greater depth of experience to their college lives. As Barnett and Caffarella (1992) put it, "the comparatively richer life experiences of the adult have been cited by nearly all writers as a key factor in differentiating adult learning from child learning" (p. 11). Consequently, colleges and universities need to work differently with adult students than they do with students in the traditional college-going age range. In the following paragraphs, adult 
learners will be defined and the differences between adult students and traditional (i.e. younger) students will be addressed.

\section{Adult Learners Defined}

Understanding exactly what defines an adult student is complex. Defining adult students based on age alone may miss a large number of young people in the traditional college-going age (18-24) "who behave like adults with respect to educational participation"

(CAEL, 2008, p. 1). Nonetheless, most analysts define adult students as those who are 25 years of age and older, because age "acts as a surrogate variable that captures a large, heterogeneous population of adult students who often have family and work responsibilities as well as other life circumstances that can interfere with successful completion of educational objectives" (National Center for Education Statistics, 2018). As Macdonald (2018) has noted, older students often have at least one of the following characteristics:

"[They] attend school part-time, work full-time, [are] a veteran, have children, wait at least one year after high school before entering college, have a GED instead of a high school diploma, [are] a first-generation student, are enrolled in nondegree programs, or have reentered a college program" (p.1).

While the enrollment of the number of degree-seeking students under the age of 25 has grown more than the adult population, "future projections show that the adult population is growing at a higher percentage" (Education Commission of the States, 2018, p. 1). The National Center for Education Statistics (2016) reports that in 2015, there were 4,150,584 undergraduates who were 25 or older; $2,176,005$ were at community colleges, 1,313,312 were 
at public four-year institutions, and 661,267 were at private four-year institutions.

Undoubtedly, adult students constitute a sizable student population in higher education.

\section{How Adult and Younger Students Experience College}

Kasworm (2003) reports that adult students differ from younger students because they see themselves differently as students, often study on a part-time basis, and are not as involved in campus activities outside the classroom. Fairchild (2003) points out that in contrast to many younger students, higher education is only one of many activities they are involved in. In addition to higher education, adults are often employed with full-time jobs, are caregivers to their children and aging family members, are community leaders and are volunteers (Fairchild, 2003). Adult students view themselves not only as students, but as parents and employees as well. Younger students often view being a student as their primary role. This is confirmed by National Center for Education Statistics data (see Table 1 below) showing that older students are more likely than younger students to view themselves as employees who study rather than students who happen to be employed. 
Table 1

Percentage of Adult Students Who View Themselves As Employees Versus Students Who Are Employed

\begin{tabular}{|c|c|c|c|c|}
\hline Student age group & $\begin{array}{r}\text { Student working to } \\
\text { meet expenses }\end{array}$ & $\begin{array}{r}\text { Employee enrolled } \\
\text { in school }\end{array}$ & Did not work & Total \\
\hline & (\%) & (\%) & (\%) & \\
\hline All students & 41.0 & 21.3 & 37.7 & $100 \%$ \\
\hline \multicolumn{5}{|l|}{ Age groups as of $12 / 31 / 2011$} \\
\hline $19-23$ years & 50.6 & 10.5 & 38.9 & $100 \%$ \\
\hline 24-29 years & 37.7 & 31.2 & 31.1 & $100 \%$ \\
\hline $30-39$ years & 30.0 & 37.9 & 32.1 & $100 \%$ \\
\hline 40 years or older & 23.5 & 40.1 & 36.4 & $100 \%$ \\
\hline
\end{tabular}

Source: National Center for Education Statistics, 2016 
As such, adult students experience college differently than younger students. Adult students spend less time on campus (Donaldson \& Graham, 1999). For adult students, the college classroom - and not campus activities (e.g. clubs and other registered student organizations) - connects them with their student peers and instructors (Donaldson \& Graham, 1999). Their success in what Donaldson and Graham (1999) call the "connecting classroom" (p.30) allows for positive self-evaluation of their role as a college student. They make sense of classroom material through reflection on their prior experiences as well as on their experiences as employees, parents, and community members in the current "life-world environment" (Donaldson \& Graham, 1999, p. 31). This vast experience base, along with the adult student's engagement in the life-world environment, make participation in out-of-class campus activities, which are so essential to younger traditional students, impractical and unnecessary for adult students. For adult students, the "connecting classroom" becomes the essential point of engagement with the college.

Adult students often have extensive experiences to share, and the institution needs to create environments - connecting classrooms - that help them leverage those experiences in classroom learning. Creating opportunities for adult students to connect with one another while in the classroom is key to helping them put the theory they learn in the classroom into real-world applications. More specifically, offering classroom opportunities for action research and enhanced student-to-student interactions fosters a sense of involvement among these students without adding to the time burdens they already face (Graham \& Donaldson, 1999). By offering student involvement opportunities within the classroom, adult students can 
integrate themselves both academically and socially into the institution without being involved in traditional campus clubs and organizations.

\section{Implications for Practice}

Because adult students balance multiple roles and do not view themselves primarily as students, college services need to be revised for these students. For example, the traditional college orientation process focuses on the challenges faced by young people as they leave home for the first time and adjust to living on their own. Often, these orientations cover rules for living in the residence halls and ways students can get involved on campus. The intent is to provide a transition from living at home with parents to living on their own in a residence hall. But the needs of adult students are much different, and an orientation program specifically designed for them must address different challenges, such as juggling work and family obligations in addition to their coursework. Additional topics important to older students include childcare options, flexible work hours with employers, and involving family members in college activities. Rice (2003) suggests an orientation that provides "all members of the adult students' families' information about the challenges, joys, and possible barriers in the enrolled student's life" (p. 55).

In addition to rethinking student orientations, colleges may also need to help faculty members teach in ways that allow adults to relate course content to life and world experiences. One instructional approach that will help adult students is self-directed learning, defined as a "process of learning in which people take the primary initiative for planning, carrying out, and evaluating their own learning experiences" (Merriam, Caffarella \& Baumgartner, 2007, p. 110). Brookfield (1993) asserts that educators should give learners as much control as possible in the 
learning process. He feels strongly about this because giving learners control gives dignity to learners and their experiences. Self-directed learning allows adult students to take control of their learning opportunities and be responsible for their individual learning experiences.

The learning goals of adult students are also furthered through the instructional process of andragogy, which is defined as the methods or techniques used to teach adults in ways that focus on their life situations (Merriam, Caffarella \& Baumgartner, 2007). Malcolm Knowles (1980), an early adopter of andragogy, posits that andragogy is based on six major assumptions. Those assumptions include the following. First, as a person matures, their personality goes from dependence to self-directing. Second, adults accumulate a reservoir of experiences that serve them well in learning new concepts. These experiences are varied (i.e. motivations, backgrounds, learning styles) which in turn creates a diverse student population and requires an emphasis in individualism in adult education. Third, adults are goal oriented. Fourth, adults want relevancy in their learning. Fifth, adults are practical (Knowles, 1980) and they want to learn things that will help them in everyday situations so that they can apply them in their day to day activities. Sixth, Knowles (1980) asserts that the classroom climate for adult students should make adults feel supported. Echoing the tenets of andragogy, Cross (1981) suggests that children (traditional students) have been conditioned to have a "subject-centered orientation" (p. 189) to most learning, whereas adults tend to have a problem-centered orientation. Adult students often want to apply tomorrow what they've learned in the classroom today, and this needs to be the mindset of instructors who are looking for the best ways to teach adult students. 
It is also important to consider that because adult students may already have learned course material through non-collegiate experiences (e.g., through employment or the military), procedures need to be in place to assess and award credit for prior learning. The Council for Adult and Experiential Learning (CAEL) defines prior learning assessment as a process for evaluating knowledge and skills for which college credit can be awarded (CAEL, 2018). This knowledge and these skills typically come from on-the-job learning, corporate training, independent study (perhaps through massive open online courses), military service, or volunteer service (CAEL, 2018). The knowledge and skills gained from these experiences translate into college credit after an adult student provides documentation of what he or she has learned through these experiences. The adult student may write a portfolio, take a standardized test, or provide industry-recognized certificates as justification for the award of college credit (CAEL, 2018). Awarding credit for prior learning is essential in working with adult students who wish to complete college degrees in a timely manner.

Finally, common understandings of student involvement need to be rethought. As noted above, Graham and Donaldson (1999) stress that out-of-class activities that reinforce classroom learning take place in different settings for younger and older students. Adult students are much less involved in campus activities and instead are involved in caring for their families and in civic and community activities (Graham \& Donaldson, 1999). Even though adult students are not involved in campus activities as much as traditional students, Graham and Donaldson (1999) found that adult students' growth in academic and intellectual development is equal to or greater than that of traditional students, a phenomenon they attribute to the students' "life-world environment" (p. 28). Thus, family life, as well as involvement in job and 
community activities, provide older students with the same benefits that traditional students enjoy through their involvement in campus activities. Since adult students are involved in activities outside of campus rather than on campus, there needs to be a way to connect the college classroom experience with real world experience that is essential to the growth and development of adult learners.

It is no secret that there are many differences between traditional and adult students. Many of the differences have been illustrated in this section of the paper. These differences must be acknowledged so that adult students can be understood and served by higher education institutions as they transfer from the community college to the university.

\section{Conceptual Framework}

A two-part conceptual framework has been used for this study. The first part of the framework draws from Cross's (1981) chain of response (COR) model which is a theory of how adults determine whether to participate in formal learning, such as a degree program. One portion of this model identifies three barriers to adult learning: situational, institutional, and dispositional. These barriers are faced by adult students who transfer from community college to a university. Situational barriers are obstacles that "arise from one's situation in life at a given time" (Cross, 1981, p. 98). In their study, Zhang, Lui, and Hagedorn (2013) interviewed an adult transfer student who faced situational barriers. His wife was sick with cancer and she was unable to work. They had two small children who needed constant care, and the family depended on his work salary for their livelihood. This adult student faced many situational barriers in his quest to complete his college degree. Institutional barriers are defined as procedures and rules that "discourage working adults from participating in educational 
activities..." (Cross, 1981, p. 98). An example is when a higher education institution offers courses during the daytime when adult students are unable to participate due to their work schedules. Dispositional barriers include "attitudes and self-perceptions about oneself as a learner" (Cross, 1981, p. 98). An example of this is when an adult student feels he or she is too old to learn (Cross, 1981). These barriers are faced by students of all ages. But the situational, institutional and dispositional barriers faced by younger students may be different than those faced by adult students. These barriers lead us to consider services that eliminate these barriers for adult students.

The second part of the framework is the Donaldson-Graham model of adult learning outcomes, which as noted above, situates student involvement in the "connecting classroom" and the "life-world environment," and leads us to consider ways of teaching and engaging adult students. The model features six major elements that are related to adults' undergraduate collegiate experiences: (a) prior experience and personal biographies, (b) psychosocial and value orientations, (c) adult cognition, (d) the connecting classroom (e) life-world environment and (f) college outcomes. "Adults come to the collegiate experience with rich personal biographies. These personal biographies are influenced by prior experiences in the real world..." (Donaldson \& Graham, 1999, p. 29). The psychosocial and value orientations are the "social conditions, the values, and the psychological motivations that influence adults' abilities to learn and remain in college" (Donaldson \& Graham, 1999, p. 29). The adult cognition element "focuses on the knowledge structures and learning processes adults bring to college (prior experience and personal biographies) as well as those they develop concurrently in their in-class (connecting classroom) and out-of-class experiences (their life-world environment)" 
(Donaldson \& Graham, 1999, p. 31). This model emphasizes the role of the adult's past and present experiences in his or her learning development, as well as the Need to design classrooms to enhance learning by using action research in real-world settings, addressing real-world problems or practices associated with work or family life, problem based learning applications, opportunities for peer teaching, and chances to create learning that will benefit the community (Donaldson \& Graham, 1999, p. 37). Cross's typology of barriers, as well as the Donaldson-Graham model, offer useful frameworks for thinking about services for adult students. Their influence can be seen, for example, in the principles for effective work with adult students that have been established by the Council for Adult and Experiential Learning (CAEL). They emphasize the need for institutions to "adapt to the changing expectations of external stakeholders" (CAEL, 2018, para. 1), rigorously assess student learning both through classroom experiences as well as experiences in non-collegiate settings, offer "an array of payment options for adult learners" (CAEL, 2018, para. 3) to offer payment choices, discuss life and career goals before enrollment "to help learners reach their goals" (CAEL, 2018, para. 4), conduct outreach to adult learners "by overcoming barriers in time" (CAEL, 2018, para. 5) so that they can have access to education, use technology for "timely information" (CAEL, 2018, para. 6), create partnerships with employers to develop "educational opportunities" (CAEL, 2018, para. 7), "assist adult learners using comprehensive academic and student support systems" (CAEL, 2018, para. 8), work with faculty to use "multiple methods of instruction for adult learners" (CAEL, 2018, para. 9) and provide transitions or pathways that lead from college programs to "educational and career goals" (CAEL, 2018, para. 10) for adult students. 
These principles are examples of actions that put the Cross COR model and the Donaldson-Graham framework into action. For example, the CAEL principle concerning financing "promotes choice using an array of payment options for adult learners" (CAEL, 2018, para. 3) so that they have financial flexibility in paying for their education. This addresses the potential situational barrier of limited resources. Flexibility in payment options helps adult students pay for their education in ways that best suit their individual circumstances. As another example, the CAEL principle of outreach promotes "outreach to adult learners by overcoming barriers of time, place, and tradition in order to create lifelong access to educational opportunities" (CAEL, 2018, para. 5). By offering courses in a variety of formats, adult students can choose which works best for them, thereby eliminating the institutional barriers posed by course schedules that are convenient only for full-time younger students who are not burdened with job or family obligations.

Finally, the two CAEL principles dealing with support systems and the teaching-learning process, address dispositional barriers. The student support principle encourages institutions to assist adult learners by "using comprehensive academic and student support systems ... to enhance students' capacities to become ... lifelong learners" (CAEL, 2018, para. 8). Institutions need to provide support services for adult learners who need confidence and understanding as they complete higher education. The principle related to the teaching-learning process encourages faculty to use "multiple methods of instruction" for adult learners so that classroom concepts can be connected to useful knowledge and skills (CAEL, 2018, para. 9). These multiple methods of instruction allow adult students several ways of connecting what they learn in the classroom to their lives, which helps to improve attitudes and self-perceptions. 
The CAEL principles also reflect the Donaldson and Graham model of adult learning outcomes. The principle related to life and career planning can address the elements of prior experience and personal biographies as well as student psychosocial and value orientations. The life and career-planning principle addresses "adult learners' life and career goals before or at the onset of enrollment in order to assess"... and "help learners reach their goals" (CAEL, 2018, para. 4), and the principle of assessment of learning outcomes acknowledges learning as the product of both collegiate and noncollegiate experiences. Two of the elements emphasized by Donaldson and Graham - adult cognition and the connecting classroom - can be addressed by the CAEL principle concerning the teaching-learning process, which highlights faculty strategies, ("including experiential and problem-based methods") that help adult learners "connect curricular concepts to useful knowledge and skills" (CAEL, 2018, para. 9). Finally, the CAEL principle concerning transitions can address the life-world environment of the DonaldsonGraham model of adult learning outcomes. This principle emphasizes the need for institutions to provide "guided pathways that ... ensure that adult students' learning will apply usefully to achieving their educational and career goals" (CAEL, 2018, para 10.)

Cross's typology of barriers to adult learning, as well as the Donaldson-Graham model of adult learning outcomes, offer useful frameworks for thinking about services and instructional approaches that eliminate institutional barriers to their success, and enhance their learning and engagement with the curriculum. The next section of the paper turns to the specific focus of the proposed study: the transfer of adult students from community colleges to universities. 


\section{Helping Students Transfer: Four Dimensions}

Efforts to help students transfer from community colleges to four-year institutions fall into four inter-related categories or dimensions: the bureaucratic dimension, the social dimension, the curricular dimension and the student services dimension. The bureaucratic dimension deals with rules and policies that are created to make the transfer process easier. The social dimension focuses on the ways colleges and universities assure that students feel involved and included even as they move from an institution with which they are familiar to an institution in which they are newcomers. The curricular dimension entails the joint efforts of community colleges and universities to assure that their curricula are aligned. The student services dimension focuses on programs and services that help students negotiate the transfer process. These dimensions are defined and discussed below along with implications for adult learners.

\section{Bureaucratic Dimension}

Many of the efforts undertaken to help students successfully transfer from community colleges to universities are bureaucratic in nature. That is, they entail rules and policies that are put in place to make the transfer process more effective. The rules and policies that are commonly discussed in the literature on transfer students include those governing articulation agreements and dual-admission agreements.

Articulation agreements are ways to move student academic credits from point A to point B, or from one institution to another (Cohen, Brawer \& Kisker, 2014). More specifically, articulation agreements are defined as formal collaborative agreements between educational institutions that aid a student in completing a program of study at one higher education 
institution and using the credits they've accrued, to attain a degree at another institution (O'Meara, Hall, \& Carmichael, 2007). Many of these agreements are called institutional articulation agreements; they are negotiated between specific community colleges and universities, helping transfer students to move seamlessly from the community college to the university by guaranteeing that courses taken at the community college level will count towards a baccalaureate degree. O'Meara, Hall, and Carmichael (2007) posit that "the most important reason for developing articulation agreements is to improve access: giving students more options and smoothed pathways to achieving degree completion" (p. 14). An example of an institutional articulation agreement can be seen in the collaboration between Danville Area Community College and Illinois State University. Agri-business students who complete the appropriate requirements for an Applied Science degree at Danville Area Community College and who are admitted to Illinois State University, are eligible to pursue a Bachelor of Science degree in Agri-business (Illinois State University, 2018). This articulation agreement maps out a smooth pathway for these students to achieve degree completion.

It is important to note that another type of articulation agreement exists. In addition to institutional agreements, there are also statewide articulation agreements. The Illinois Articulation Agreement (IAI) has led to statewide agreements covering both lower division general education college course requirements and lower-division college course requirements for selected majors (iTransfer, 2018). The IAI has established a general education core curriculum, allowing students to transfer from one institution to another with the assurance that lower-division general education requirements have been met (Bers, 2013). "The IAI covers all public universities and a number of private universities" (Bers, 2013, p. 19). 
In addition to institutional and state articulation agreements, the bureaucratic dimension also includes dual-admission agreements. These agreements are negotiated between individual institutions and provide students the opportunity to be accepted by both a community college and a transfer institution at the same time and ensure transfer so long as certain requirements are completed (Bers \& Younger, 2011). These agreements provide transfer students the opportunity to take courses concurrently at both institutions to work on degree requirements at each school. An example can be seen in the dual-admission agreement negotiated between the Community College of Philadelphia and several surrounding universities. These partnerships allow students to earn an associate's degree at the Community College of Philadelphia and then transfer with junior standing in one of twelve different universities in the Philadelphia area to pursue a bachelor's degree (Community College of Philadelphia Dual Admission Agreement, 2018).

Joint admissions arrangements, along with articulation agreements, facilitate transfer by making transfer of credits from one institution to another more transparent and comprehensive and aligning curriculum between two-year and four-year institutions (Bers, 2013). These agreements strive to create a seamless process for students transferring from the community college to the university.

Implications for adult learners. Students of all ages benefit from these structural supports. However, the varied educational experiences of adult students might not be recognized in common transfer policies. For example, the "increased mobility of students leads to the accumulation of [college] credits from multiple sources ... (Marling, 2013, p. 85). In addition, some adult students may have earned college credits through portfolio assessments 
or other protocols used to determine how learning through workplace training, independent study, military service, or volunteer work might align with the learning expectations of college courses (American Council on Education, 2018). "The learning activities in which adults engage are as diverse as the adult learners themselves" (Hansman \& Mott, 2010, p. 16). "The comparatively richer life experiences of individual adults have been cited by nearly all writers as a key factor in differentiating adult learning from child learning" (Merriam, Caffarella \& Baumgartner, 2007, p. 423). In these cases, a key question is whether articulation agreements are as effective at facilitating the transfer of credits from multiple sources as they are at facilitating the transfer of credits earned by students who have followed a traditional path (i.e. attending one community college as a stepping stone to the university). If not, this may pose a significant institutional barrier for adult transfer students.

\section{Social Dimension}

Helping adult students transfer from community colleges to universities also has a social dimension. The social dimension is defined as students feeling involved and being included as part of the group. This sense of feeling involved or feeling a sense of belonging is a common theme in the transfer student literature.

Astin's (1984) theory of student involvement (as cited in Laanan, 2007), posits that transfer students who were highly involved both socially and academically at the community college will most likely continue this behavior when they transfer to the university.

Laanan (2007) also found in a regression analysis controlling for age, among other variables that transfer students are more likely to adjust socially to a new environment to the extent that they are involved in campus organizations and spend time with other students. 
Spending time with other students equates to making new friends. Students involved in clubs and organizations "will experience less difficulty in adjusting socially" (Laanan, 2007, p. 54). These items help students to foster a sense of belonging with the institution.

Miller (2013) states that challenges faced by transfer students at four-year institutions include lack of integration. More specifically, there is little attachment to the campus or the college experience. Often student bonding takes place during the freshman year of college and "by the time transfers have arrived on campus, they may find that students with an equivalent number of credits (i.e. juniors) have already settled into a social niche" (Miller, 2013, p. 46). It can be difficult for transfer students to develop friendships and social bonds. Likewise, transfer students may have little interest in socializing beyond the classroom and may "simply come to campus to complete their coursework requirements in order to complete the degree" (Miller, 2013, p. 46).

Implications for adult learners. Students of all ages face social issues in transferring to a new college or university. However, the marginalization of adult students may not be fully recognized in the current transfer literature. Adult students are much less involved in campus activities and instead are involved in work-related activities, in caring for their families and in civic and community activities (Graham \& Donaldson, 1999). Add into this equation the tendency for adult students to be viewed as lesser importance to the "traditional core student group" (Sissel, Hansman \& Kasworm, 2002, p. 18) and there is cause for concern that adult transfer students face formidable situational and institutional barriers. Still, previous studies such as Laanan's do not account for the "connecting classroom" and "life-world experiences" that, according to Donaldson and Graham (1999) compensate for a lack of involvement in 
campus activities. In a more recent qualitative study of 31 community college transfer students ranging in age from 18 to 48, Lester, Leonard and Mathias (2013) found that most experienced "social engagement outside of the college within familial relationships or community-based groups" (p. 215) and viewed the classroom as the focal point of the collegiate experience. These aspects of the social dimension of student transfer have yet to be fully examined in the literature.

\section{Curricular Dimension}

In addition to a bureaucratic and a social dimension, a curricular dimension exists in helping students transfer from a community college to a university. This curricular dimension can be defined as whether the curricula for community colleges and universities are aligned in terms of course content and expectations for learning. Cohen and Brawer (1987) emphasized this, noting that the transfer function of the community college cannot be understood without a consideration of what is being taught and how teaching aligns with university expectations. In order to be accepted as full partners in higher learning, the community college faculty have had to "arrange their curricula in the university image" (Cohen, Brawer \& Kisker, 2014, p. 267). The curricular dimension focuses on the development of curricular pathways that provide a bridge between lower-division studies at the community college and upper-division studies at the senior institution.

These pathways must go beyond articulation agreements and include programs, curricula, and support services that are tailored to the learning goals of each transfer student (Shugart \& Harrison, 2011). In addition, colleges and universities must work together to ensure that these student pathways are in place at the beginning of the students' higher education 
journey (Poisel \& Joseph, 2011). To this end, course equivalency guides are often provided by many institutions so that students and advisors can determine how a community college course will transfer to a receiving institution (Bers \& Younger, 2011). The coordination of a common course numbering system between community colleges and universities also helps students to understand which courses transfer (Fann, 2013). Transfer information "must be readily available, clearly posted in multiple modalities, and complete at both institutions [community colleges and universities]" (Ellis, 2013, p. 83). The ultimate goal is to create a positive environment for "student aspirations and planning" (Shugart \& Harrison, 2011, p. 45).

Implications for adult learners. Students of all ages can benefit from the collaboration between community colleges and universities to ensure that appropriate student pathways are created. However, the importance of this topic to adult students may not be recognized fully in the transfer literature. A key question to think about is whether the collaboration between community colleges and universities is inclusive in thinking about institutional requirements and how they will impact adult students. Adult students who participate in higher education "exhibit the phenomenon of stopping out, (i.e. dropping out with the intention of returning), which suggests the need for different institutional perspectives" than those guiding work with younger students (Ginsburg \& Wlodkowski, 2010, p. 28). Adult students experience "personal and environmental barriers that disrupt their learning and require episodes of departure from their programs" (Ginsburg \& Wlodokowski, 2010, p. 28). Typically, adult students will return once circumstances in their lives allow them, though it may take months or years before they return. The student curricular pathways discussed in the literature (e.g. Bailey, Jaggers, \& Jenkins, 2015) often assume a steady pattern of completion toward a degree. They do not 
consider the probability that pathways for adult students may span the course of several months or years, and that curricular policies and procedures that are valid when students begin their postsecondary studies may not be active and valid when students return after stopping out.

In addition to providing more flexible pathways, transfer for many adult students can be facilitated by extending opportunities for baccalaureate study to those completing vocational programs. An important curricular development that may affect the transfer of adult students is the development of Applied Baccalaureate $(A B)$ degrees. These $A B$ degrees place emphasis on the transfer of college credits from the Associate of Applied Science (AAS) degree, an ostensibly terminal credential, to a baccalaureate degree (Bragg \& Soler, 2017). The AB degree, known as a career pathway model, "integrates career and technical education as well as academic studies from the beginning to the end of a student's four-year program of study (Bragg \& Soler, 2017, p. 127). It is hard to know what the impact of the AB degree will be on adult students, but these credentials could open transfer opportunities for at least some who may otherwise find themselves unable to extend their studies beyond the associate's degree. The Illinois Community College Board (2016) for example, reports that in 2015, older students were more likely than younger students to take advantage of career-technical programs: "Eight out of ten (82.4 percent) graduates over 30 earned Career and Technical Education degrees and certificates. Generally, the proportion of Career and Technical Education graduates increased as student age advanced" (p. 15). 


\section{Student Services Dimension}

The student services dimension is also present when adult students transfer from a community college to a university. This dimension entails programs and services undertaken to help students negotiate the transfer process. Examples of these services include orientation, academic advising, and transfer centers.

Orientation for transfer students is now viewed as an important tool for retaining students while helping them move toward completing a bachelor's degree (Marling, 2013). Many receiving institutions "have begun to offer orientation programs specifically for incoming transfer students, using on-campus, online and hybrid approaches" (Bers \& Younger, 2011, p. 32). Transfer student orientations "should include advising, course registration and time to meet" with faculty from the academic department (Furbeck, 2011, p. 24). In addition, Furbeck (2011) posits that the opportunities to ask specific questions is a key component of orientations. Opportunities to "speak with current students who have transferred," as well as time to take care of errands "such as purchasing a parking pass and obtaining a student ID" are also important aspects of the orientation (Furbeck, 2011, p. 24).

In addition to orientation, academic advising is a specific service that can help transfer students. Advising can be designed for first-year students to help them "make better decisions and begin their induction into the pathway as a single program," instead of a pair of articulated programs (Shugart \& Harrison, 2011, p. 45). Academic advising is a multifaceted process and transfer students need advising from the perspective of both the college they are transferring from and the college they are planning to transfer to (Bers \& Younger, 2011). More often, 
transfer students describe their academic advising experiences as frustrating due to inaccurate information and a lack of access to advisors (Fann, 2013).

Transfer centers are also helpful. They "can provide support and advocacy for students whether they are leaving an institution or beginning at a new one," and are ideally a place where all offices and departments that respond to questions about transfer would consolidate and serve as a one-stop shop for students (Collins, Navarro \& Stinard, 2011, p. 55). These centers also help to provide a "transfer-receptive culture" that ensure a welcoming and successful environment for new transfer students (Herrera \& Jain, 2013, p. 58).

Orientation, academic advising and transfer centers are all important student services. Along with these services, "registration and transfer processes can be made less duplicative and easier for all concerned" (Shugart \& Harrison, 2011, p. 45) and can be coordinated for the entire degree program. Cross-institutional training and online degree audit systems are also ways that community colleges and universities can work together to provide a smooth pathway (Miller, 2013). Aligning courses at the community college with the courses at the university provides a greater likelihood that the community college courses will transfer smoothly (Bers \& Younger, 2011).

Implications for adult learners. Undoubtedly, students of all ages benefit from student services. However, the specific needs of adult students may not be recognized in these services. For example, adult students need an orientation that includes the challenges they face juggling work and family obligations in addition to their coursework. Additional topics for an orientation may include childcare, working with employers to have flexible working hours and involving family members in college activities. As mentioned previously, Rice (2003) 
suggests an orientation that provides "all members of the adult students' families' information about the challenges, joys, and possible barriers in the enrolled student's life" (p. 55). In these cases, a key question to think about is whether the student services that are currently in place for transfer students take into account the special needs of adult students.

\section{Conclusion}

Writings on transfer and on college work with adult students offer relatively few insights into services that will help adult students transfer from community colleges to universities. Still, several things seem to be important for these students. From the bureaucratic perspective, the transfer of adult students can be facilitated to the extent that institutional articulation agreements are negotiated between community colleges and universities to improve student access. The creation of statewide articulation agreements, such as the Illinois Articulation Initiative, and dual-admission agreements negotiated between individual institutions help students so that they can take courses at both institutions concurrently. In addition, joint admissions agreements, which allow transfer of credits from one institution to another by aligning curriculum, are also important for adult students. All of these items are reflected in the first draft of the questionnaire (found in Appendix A) to the extent that articulation agreements facilitate credit earned by community college students in the military, on the job, or in other noncollegiate settings.

From the perspective of the social dimension, the transfer of adult students can be facilitated to the extent that faculty and students interact, which helps adult students to socially be engaged. Adult transfer students can also be aided in combating social issues and lack of integration with the "connecting classroom" and "life-world experiences" that, according 
to Donaldson and Graham (1999) compensate for a lack of involvement in campus activities. These items are also reflected in the questionnaire (Appendix A) to the extent that adult students need to feel engaged and welcomed into a higher education community.

From the perspective of the curricular dimension, the transfer of adult students can be facilitated to the extent that institutions should think about the experience of each transfer student to create individual pathways based on the student's personal goals and life circumstances (Shugart \& Harrison, 2011). The coordination of a common course numbering system between community colleges and four-year institutions will help to alleviate confusion on coursework. The development of Applied Baccalaureate $(A B)$ degrees will provide an opportunity for the transfer of college credits from the Associate of Applied Science (AAS) degree, an ostensibly terminal credential, to a baccalaureate degree (Bragg \& Soler, 2017). These items are also reflected in the questionnaire, in questions that ask whether courses are being offered at convenient times and locations for busy, working adults, as well as whether bachelor's degree programs are being offered for place bound students either online or through other convenient locations.

From the perspective of the student services dimension, the transfer of adult students can be facilitated to the extent that orientation and academic advising geared specifically for adult students should be offered. Transfer centers should be available to work with adult students. These items are reflected in the questionnaire, in questions that ask whether student services are offered at the community college, four-year public institution and four-year private institution. 
These insights were used as a tentative guide for the construction of a list of statements that were included in the questionnaires sent to transfer coordinators. The next chapter explains the steps taken to finalize the questionnaire that was ultimately administered to transfer coordinators statewide. Chapter three explains how data were collected and analyzed. 
CHAPTER III: METHODOLOGY

Osam, Bergman, and Cumberland, 2017 state that "the composition of the college population has shifted from a bastion of full-time, 18 to 22 year old students to a far more diverse population that typically works part-time or full-time, has greater family commitments, is over 24, and is juggling various competing responsibilities while attending college" (p. 54). Since adult students continue to participate in postsecondary learning, it is time for colleges and universities to take a close look at the services they offer for students, and to evaluate whether these items are appropriate for the specific needs of adult students who plan to transfer. This was the research problem that guided this study. In addition to the research problem, three research questions were posed:

1. What do transfer coordinators perceive their colleges are doing to help adult students transfer from community colleges to universities?

2. What do transfer coordinators perceive their colleges should be doing to help adult students transfer?

3. Is there a gap between what coordinators perceive that their colleges are doing to help adult students transfer from community colleges to universities and what they perceive that their colleges should be doing?

\section{Research Design}

This study was an exploratory, mixed method study. Berman (2017) defines the exploratory mixed method study characterized as "an initial qualitative phase of data collection and analysis, followed by a phase of quantitative data collection and analysis, with a final phase of integration or linking of data from the two separate strands of data" (p.1). This study follows 
this definition since it begins with asking the pilot group of transfer coordinators for information, which is qualitative in nature. Then all transfer coordinators listed on the iTransfer web site were asked to complete a survey, which is quantitative. Finally, the qualitative data from the transfer coordinators and the quantitative data from the survey were integrated together to help understand the findings of the research study.

\section{Instrumentation and Data Collection}

The research study was conducted in three stages. Those stages included questionnaire development, administering the questionnaire and follow-up telephone conversations. Each stage is discussed in detail below.

Stage One: Questionnaire Development. Telephone conversations (in some cases group telephone conversations and in others individual telephone conversations depending on the availability of each of the transfer coordinators) involving transfer coordinators were convened to discuss the problems adult students face when transferring from community colleges to universities. The conversations also elicited the perceptions of what transfer coordinators believe colleges and universities can be doing to help adult students to transfer successfully. A second set of telephone conversations (in some cases group telephone conversations and in others individual telephone conversations depending on the availability of each transfer coordinator) were held to review an initial draft of two questionnaires: one meant for the transfer coordinators at receiving four-year institutions, and the other meant for the transfer coordinators at community colleges (see Appendix A). These questionnaires were derived from both the literature as well as from key ideas emerging from the first round of telephone conversations. It is important to note that the questionnaires were not pre-made surveys; they 
were original surveys, based on key literature and information collected from transfer coordinators. Suggestions made by participants in all telephone conversations were used to complete the final version of the questionnaires, which were submitted to the Institutional Review Board for approval prior to proceeding with the second stage of the study. The purpose of this stage was to elicit the expertise of the transfer coordinators so that this information could be included within the questionnaires. The expertise of all transfer coordinators was solicited within this stage of the study. These transfer coordinators were considered the pilot group for this study.

Stage Two: Administering the Questionnaire. Transfer coordinators at Illinois two-year and four-year colleges were invited to complete the questionnaires, which were administered on Survey Monkey. The initial invitation was sent in a letter that provided the URL for the survey. The mailing was followed up with two e-mail reminders. Contact information for the transfer coordinators can be found on the website of the Illinois Articulation Initiative (https://itransfer.org/transfercoordinators/transfercoorddirectory.php). It is important to note that the transfer coordinators who participated in stage one and stage three of the study (the pilot group) did not complete the survey. The survey was anonymous; the researcher did not know which transfer coordinators responded. The purpose of this stage of the study was to ask for participation from transfer coordinators in completing the survey, which provided data to analyze and to answer the research questions posed for the study.

Stage Three: Follow-up Telephone Conversations. Follow-up telephone conversations, comprised of the same initial members, elicited perceptions of what the survey findings suggest about implications for practice. The purpose of this stage of the study was to glean any 
additional information that transfer coordinators wished to share about the study results. In addition, the other purpose of this stage of the study was to elicit ideas for future research from transfer coordinators on this important topic.

\section{Stage One: Developing the Questionnaires}

Two questionnaires for this research study were created: one that was sent to transfer coordinators at receiving four-year institutions, and the other that was sent to transfer coordinators at community colleges. The questionnaires were created in order to elicit transfer coordinator perceptions of the gap between what is being done at their institutions to help adult students transferring from community colleges to four-year institutions, and what should be done. These questionnaires were created by hosting two initial rounds of telephone conversations with selected transfer coordinators. These transfer coordinators were selfselected. The first round of conversations was intended to elicit perceptions of the challenges adult students face when transferring and of the things colleges and universities can do to help adult students successfully transfer. The second round of conversations were intended to elicit reactions to draft questionnaires constructed based on findings in round one as well as on the basis of the literature review in chapter two of the study.

\section{Recruitment of Participants}

The recruitment of focus group participants occurred by asking Rita Pearson, transfer coordinator at Eastern Illinois University, for a list of transfer coordinators at both community colleges and four-year institutions in Illinois who have experience in working with adult students and who would be willing to participate in this research study. Ms. Pearson was selected to assist with this task because she is a prominent, well-respected transfer coordinator 
who has a vast amount of experience in this important role. In total, Rita suggested 16 transfer coordinators and provided their names and email addresses. These coordinators were from community colleges, public four-year institutions and private four-year institutions.

I sent each of the transfer coordinators an email, asking for their participation. From the initial email I sent, I received response from two transfer coordinators who were interested in participating. I then sent a follow up email to the other 14 transfer coordinators who had not responded to the initial email. I did not receive any response from my follow up email.

Next, I personally called those who had not responded to either of my emails and asked if they would be interested in participating in the focus group process. I received good feedback from this effort, which allowed me to have enough participants to host the telephone conversations. As a result of the personal telephone calls, I received four more participants.

I conducted a first round of telephone conversations (in some cases group telephone conversations and in others individual telephone conversations) with the six participants who volunteered. I quickly learned I did not have any transfer coordinators involved who worked at private four-year institutions. All the feedback I received was from transfer coordinators who work at community colleges (three participants) and four-year public institutions (three participants). I needed to capture feedback from those who work in private four-year institutions in order to capture thoughts and perspectives from each type of transfer coordinator in Illinois. In order to solicit feedback from transfer coordinators at private fouryear institutions, I examined the transfer coordinator online directory (found at https://itransfer.org/transfercoordinators/transfercoorddirectory.php) to recruit additional participants. I collected names and contact information for each private four-year institution 
that listed their transfer coordinator contacts on this web page. There were 21 transfer coordinators listed. I emailed all 21-transfer coordinators on the list, to ask for their participation. I received email responses from three transfer coordinators who agreed to participate. In the end, only two transfer coordinators from the four-year private institutions participated.

In total, eight transfer coordinators - six from public institutions (three from community colleges and three from four-year public institutions) along with two from private institutions, participated in the first round of telephone conversations (in some cases group telephone conversations and in others individual telephone conversations). These transfer coordinators represented $5 \%$ of all transfer coordinators in all Illinois community colleges and four-year institutions.

\section{First Round of Conversations}

As previously mentioned, in the very first round of conversations I solicited responses from transfer coordinators at both community colleges and public four-year institutions only. In order to schedule the focus group conversations, I used Doodle polls and sent the link to each participant via email, asking them to indicate which dates and times would work best for them to participate. I sent an email message to participants with the proposed date and time of the telephone conversations as well as dial in information. One week before each conversation I emailed an informed consent form to each participant and asked them to fill it out and return it via email, fax or mail prior to the conversation. Two days before the conversations, I sent email reminders to each participant as well as the dial in information. Due to busy schedules, I conducted three telephone conversations because a common time for all 
the participants to come together could not be found. In the first conversations I captured three responses. In the second conversations, I captured the responses of two transfer coordinators. In the third conversations I captured one response from one participant. Six transfer coordinators (three from community colleges and three from public four-year institutions) participated.

After talking with transfer coordinators from community colleges and four-year public institutions, I scheduled another teleconference with the two transfer coordinators from private four-year institutions. For this group, I was able to schedule just one conversation, as a common date and time worked for both participants. With the addition of these two transfer coordinators, a total of eight transfer coordinators participated in the initial conversations. Of those eight, three were from community colleges, three were from four-year public institutions and two were from four-year private institutions.

During all these teleconferences, I asked the transfer coordinators two questions: What do you believe are the challenges adult students face when transferring from community colleges to university? What can be done to help adult students transfer successfully? As the participants spoke, I took notes, and after each conversation was completed, I immediately typed the notes into one computer document. I revisited the typed notes the following day and reviewed my recollections, looking for common themes. I then organized the themes and studied the original survey questions I created based on my literature review (Chapter Two). I began to see that some of the questions in the original survey reflected themes mentioned in conversations. I also noted some of the responses from the conversations were not reflected in the original survey, leading me to add additional questions to the survey instrument. Thus, a 
revised questionnaire was created, containing questions gleaned from both the literature as well as from the conversations with the transfer coordinators.

Several themes emerged in these conversations. Three dealt with the challenges faced by adult students in terms of life and world balance, university structure and the perception that adult students may have a mindset that is not consistent with university expectations. Four dealt with the strategies or actions institutions can take to help adult transfer students, including rethinking support services, revising policies, educating staff about adult students, and working cooperatively with other institutions across the state.

Life and world balance. The first theme that emerged in the conversations dealt with the challenges of juggling many responsibilities in addition to going to school. The transfer coordinators felt adult students are often pulled in multiple directions. They are balancing careers, family, and college studies. Adult students, the transfer coordinators emphasized, are integrating part-time study with family, work, and social obligations which makes it difficult to balance everything in their lives. This balancing act has long been recognized in the literature.

Kember (1999), for example, posits that in order to be successful in part-time study, adult students must have the support of family members, work colleagues, and others in what Donaldson and Graham (1999) called the life-world environment.

University structure. A second theme that emerged in the conversations dealt with the inadequacy of the university structure in assisting adult students. Transfer coordinators at universities were not sure they have the right support services for adult students, because faculty and staff within the institution often assume that transfer students are younger, traditional-aged students. Consequently, university structures in place for transfer students 
may not take into account the needs of adult learners, leading them to feel marginalized or unwelcome. This reflects the work of Sissel, Hansman, and Kasworm (2002), who posited that adult students are often viewed as "invisible and of lesser importance to the traditional core student group..." (p. 18). This may be evidenced by mission statements, institutional marketing or advertising, and programs or policies that are not geared to the needs of adult students. Sissel et al. argue that the adult student voice and image (older in age, married and working) are often not integrated into the ethos of the campus.

Student mindset. A third theme that emerged in the conversations is that the adult student mindset may not align with university expectations. One of the university participants argued that adult students may not give their studies the priority in their lives that universities expect. The university culture, particularly at residential institutions, may assume that academic studies and participation in campus life should be the student's number-one priority. But as noted in Chapter Two, this runs counter to the realities of the adult student population. Most adult student undergraduates are not able to be fully involved in their higher education experience, and Kasworm (2014) states there is a "disjuncture between an assumed ideal world of student engagement and the reality of adult student life commitments" (p. 69).

Provide services and support. When asked what can be done to help adult students transfer successfully, participants noted the importance of services and support geared toward adult students specifically. One transfer coordinator, for example, stated "I'm not sure we have the right support services for adult students, because we [the university] very much assume that transfer students are still young versus being adult students." This concern has been expressed in the literature as evidenced by Jacobs and Hundley (2010) who assert that financial 
assistance, "stronger student support services including academic advising, personal

counseling, tutoring and remediation" (p. 18) and an overall commitment to adult learners with a focus on meeting their needs are essential services and support to provide for adult students.

Revisiting and adjusting policies. Conversations also centered on how institutional policies should be revisited and adjusted to meet the needs of today's adult students. One participant, for example, noted that "At our school, we have a rule that any course that was taken seven years ago or longer must be taken again (for example, classes in our math and computer science department); if a student is not a math/computer science major, we need to get rid of this rule so that we give them credit for their courses that are older and count them towards the current degree they are working on." This is an example of what Cross (1981) called institutional barriers, defined as "practices and procedures that exclude or discourage working adults from participating in educational activities" (p. 98).

Educating staff about adult students. Participants were also concerned that colleges and universities need to educate staff about adult students. Some noted that many who work in higher education have not themselves been adult college students and have had few if any experiences working with adult students. Consequently, they don't often know how to assist adult students because they are uninformed about the challenges and obstacles adult students face while juggling school with all their other life responsibilities. As one transfer coordinator stated, "Our admissions counselors are young - we need to educate campus staff that students come in different shapes and sizes and campus staff need to frame conversations with potential students accordingly." This sort of professional development may help assure that "faculty and 
staff... understand the paradoxical focus and goals of adult students" and the need for "adultsupportive policies and instructional designs" ... (Kasworm, 2008, p. 30).

Working together with other institutions. Participants also noted that working together with other institutions across the state can provide opportunities to help adult students transfer successfully. Constant communication across institutions was emphasized as important. This reflects observations from Erisman and Steele (2015) who concur that "having a network of adult-friendly institutions helps promote the idea that adult student college completion is a group effort" (p. 42).

As a consequence of these conversations, I determined the original questionnaires had not addressed concerns about misalignment of university expectations with the adult student mindset. I also determined the original questionnaires had not addressed concerns about the importance of revisiting policies, educating staff, and working with other institutions. Accordingly, I added the following items to the questionnaire for transfer coordinators at community colleges:

- Our community college realizes that adult students at our institution do not always treat higher education as a priority.

- Our institution revisits academic policies and adjusts them to support adult students in our modern society.

- Non-instructional staff at our institution understand how working with adult learners may differ from working with younger, traditional students

- Our institution works with other colleges and four-year institutions across the state to 
improve services for adult students.

I also added the following items to the questionnaire for transfer coordinators at universities:

- We have found that adult students at our institution do not always treat higher education as a priority.

- Our institution revisits academic policies and adjusts them to support adult students.

- Non-instructional staff at our institution understand how working with adult learners may differ from working with younger, traditional students

- Our institution works with other colleges and universities across the state to improve services for adult students.

\section{Second Round of Conversations}

Once I revised the original survey, I began planning for the second round of telephone conversations. I sent email communications to those who participated in the first set of conversations, asking if they would participate in a second round. The email also contained a Doodle poll for them to fill out if they were interested in participating. A total of seven people ultimately participated; three were from community colleges, two were from four-year public institutions, and two were from four-year private institutions. The intention of these conversations was to review and elicit feedback on the revised questionnaires, one to be sent to the transfer coordinators at four-year institutions and the other to be sent to the transfer coordinators at community colleges.

The participants pointed to the need for editorial changes, noting for example, that although the questionnaires used the term "university," not all four-year institutions are 
designated as universities. Hence the term, the term "four-year institution" was substituted for "university". In addition, in the four-year institution survey, the term vocational was used in one of the questions. According to the transfer coordinators, this is an outdated term, and they recommended I use the terms "career tracks" or "career and technical education" in the survey instead.

Another editorial concern dealt with the question, "To what extent is your institution dependent on the enrollment of students who are age 25 and older?" This question proved to be confusing for nearly all the transfer coordinators, who indicated that they would not know the answer to this question, as they are not privy to this type of information about their institutions. Instead, the transfer coordinators suggested that the questionnaire ask, "What percent of your student enrollment is 25 years of age or older?"

The transfer coordinators also expressed confusion about the item stating that "Working with adult students is a high priority at our institution." They felt the question was vague and suggested that we instead substitute the statement, "Recruiting adult students is a high priority at our institution."

Finally, the transfer coordinators suggested instances in which questionnaire items could be combined. They specifically pointed to questionnaire statements concerning the provision of support services for adult students who plan to transfer (in the community college questionnaire) or who have transferred (in the four-year college questionnaire), as well as statements concerning the extent to which advising and other support services are geared for adult students who plan to transfer (community college questionnaire) or who have transferred (four-year college questionnaire). Transfer coordinators felt having both questions on each 
survey was confusing and that the questions could be combined into one survey question.

Based on the comments received during the focus groups, the questions were combined to form just one question instead of two questions.

The final versions of the questionnaires are provided in Appendix B. At the advice of the dissertation chairperson and methodologist, the questions were grouped into each of the four dimensions of transfer detailed in Chapter Two: the bureaucratic, social, curricular and student services dimensions. Open-ended questions were included at the end of each section, allowing respondents to note other concerns that they felt were important.

Each survey consisted of two sections. The first section asked for contextual information about the transfer coordinator's higher education institution, such as student enrollment, and the percentage of an institution's student enrollment that is 25 years of age or older. The second section consisted of paired statement questions that were worded in two different ways, one to elicit respondent perceptions of what is being done at the respondents' institutions, and the other to elicit respondent perceptions of what should be done at respondents' institutions. For example, the first statement in the community college questionnaire is as follows: "Students who are awarded credit at your college for learning in the military, on the job, or in other non-collegiate settings do find it easy to transfer those credits to four-year institutions." This is paired with the statement, "Students who are awarded credit at your college for learning in the military, on the job, or in other non-collegiate settings should find it easy to transfer those credits to four-year institutions." - "does have/what is" and "should have." For each of these paired statements, respondents selected from a five-point Likert scale (1=strongly disagree, 5=strongly agree) to rate the statements. 


\section{Stage Two: Data Collection and Analysis}

After the Institutional Review Board approved the protocol for this study, a letter and a study reference guide were mailed via U.S. postal to every transfer coordinator listed on the itransfer website as working at community colleges, public-four-year institutions, and private four-year institutions. (Transfer coordinators who participated in the initial telephone conversations were not included.) The letters and study reference guides, provided in Appendix C, explained the purpose of the study and directed the transfer coordinators to a Survey Monkey site where they could (if they chose to do so) fill out the questionnaires. A follow-up e-mail was sent to the transfer coordinators two weeks later, inviting them to participate in the survey it they had not already done so.

In total, 48 of 164 transfer coordinators contacted via mail and email responded to the surveys, yielding a return rate of $29 \%$. Descriptive statistics were employed to analyze results. Overall means on the five-point Likert scale were calculated for each statement, both in terms of respondent perceptions of what their institutions are doing and what their institutions should be doing, thereby answering research questions one and two: What do transfer coordinators perceive their colleges are doing to help adult students transfer from community colleges to universities?, and What do transfer coordinators perceive their colleges should be doing to help adult students transfer? In addition, differences between the means reflecting perceptions of what is happening and what should be happening were calculated for each statement, thereby answering research question three: Is there a gap between what coordinators perceive that their colleges are doing to help adult students transfer from community colleges to universities and what they perceive that their colleges should be doing? 


\section{Stage Three: Third Round Conversation with Transfer Coordinators}

The third and final round of telephone conversations was held after the results from both surveys were collected. These conversations included the same transfer coordinators who participated in the second round of conversations except for one person who had planned to participate but was unable to do so. A total of six transfer coordinators participated, including three from community colleges, two from four-year public institutions, and one from a fouryear private institution. Ideally, all participants would have been on the same telephone call. However, due to scheduling constraints, there were three different conversations in order to accommodate the busy schedules of the transfer coordinators. The purpose of these conversations was to obtain the transfer coordinators' perceptions of what the survey findings suggested about implications for practice. In addition, any additional information that transfer coordinators wished to share about the study results was also welcomed.

Ethical considerations were addressed with this research study. As mentioned above, informed consent paperwork was completed by the participants prior to the telephone conversations. Participants names and their associated higher education institutions were withheld from notes taken during the telephone conversations, to make sure that anonymity of participants was protected. The researcher kept the notes from the conversations in computer files that were password protected on her computer. This also protected confidentiality of both the participants and the study information they shared.

Chapter four presents an analysis of the data gathered from the surveys and final focus group conversations. 


\section{CHAPTER IV: ANALYSIS OF DATA AND RESULTS}

As noted, transfer coordinators at colleges and universities in Illinois were invited to complete two surveys at stage three of the study. One of the surveys was designed for transfer coordinators at community colleges and the other was designed for transfer coordinators at four-year institutions. There were two different surveys for transfer coordinators because not all items on each survey were applicable to both community college transfer coordinators and four-year institution transfer coordinators. Eighty-four community college transfer coordinators, 27 four-year public four-year institution transfer coordinators, and 53 private four-year institution transfer coordinators were included in the sample population. These transfer coordinators were listed on the iTransfer web site (https://itransfer.org/transfercoordinators/transfercoorddirectory.php) and were all invited to participate in the study. Transfer coordinators self-selected in order to complete the survey. Of these 164 total transfer coordinators in the sample population, 48 responded to the data. Some of the respondents did not fully complete the survey. Due to these missing data, the number of respondents providing usable data for analysis was reduced to 35 , representing a response rate of $21 \%$. Of these 35 respondents, seven were from public four-year institutions, eight were from private four-year institutions, and 19 were from community colleges. Table 2 summarizes the demographics of the 35 participants. 
Table 2

Survey Response Rate by Type of Institution

\begin{tabular}{|c|c|c|c|c|}
\hline Item & & Type of Institutio & & Total \\
\hline & $\begin{array}{l}\text { Community } \\
\text { colleges }\end{array}$ & $\begin{array}{l}\text { Public four-year } \\
\text { institutions }\end{array}$ & $\begin{array}{l}\text { Private four- } \\
\text { year } \\
\text { institutions }\end{array}$ & $\begin{array}{l}\text { Total across al } \\
\text { sectors }\end{array}$ \\
\hline $\begin{array}{l}\text { Number of transfer coordinators } \\
\text { to whom the questionnaire was sent }\end{array}$ & 84 & 27 & 53 & 164 \\
\hline $\begin{array}{l}\text { Number of transfer coordinators who provided usable } \\
\text { responses to the questionnaire }\end{array}$ & 19 & 7 & 8 & $35^{\mathrm{a}}$ \\
\hline Response rate (\%) & $23 \%$ & $26 \%$ & $15 \%$ & $21 \%$ \\
\hline
\end{tabular}


Table 3 provides information about the institutions these transfer coordinators represent, including total enrollment, the number of students who transferred from the institution in the fall of 2016 (in the case of the community colleges), and the number of students transferring to the institution from community colleges in the fall of 2016 (in the case of four-year institutions). It is interesting that for both community college and four-year institutions, the greatest number of transfer coordinators responded that 21 to $40 \%$ of their institutional enrollment is $\mathbf{2 5}$ years of age or older. This information seems as though it could fall in line with the data collected by the National Center for Education Statistics (2016) that stated $35 \%$ of students at the nation's community colleges were 25 years of age and older, $23 \%$ of students at the nation's four-year private institutions were 25 years of age and older, and $19 \%$ of students at the nation's four-year public institutions were 25 years of age and older. Perhaps this study mirrors the nationwide trends of adult students who are enrolling in college degree program. 
Table 3

Contextual Information Reported On Community College Survey and Four-Year Institution Survey

\begin{tabular}{|c|c|c|}
\hline Questionnaire Item & Community College Responses & Four-Year Institution Responses \\
\hline \multicolumn{3}{|c|}{$\begin{array}{l}\text { What is your enrollment at your } \\
\text { institution? }\end{array}$} \\
\hline Under 1,000 & 1 & 1 \\
\hline $1,000-4,999$ & 8 & 3 \\
\hline $5,000-9,999$ & 6 & 3 \\
\hline 10,000 to 19,000 & 1 & 3 \\
\hline $20,000+$ & 2 & 4 \\
\hline \multicolumn{3}{|c|}{$\begin{array}{l}\text { What percentage of your institution's } \\
\text { student enrollment is } 25 \text { years of age or } \\
\text { older? }\end{array}$} \\
\hline 0-20 percent & 1 & 5 \\
\hline 21-40 percent & 9 & 6 \\
\hline 41-60 percent & 3 & 0 \\
\hline $61-80$ percent & 2 & 0 \\
\hline $81-100$ percent & 0 & 0 \\
\hline \multicolumn{3}{|c|}{$\begin{array}{l}\text { What was the magnitude of transfer } \\
\text { students who transferred from your } \\
\text { community college to a four-year } \\
\text { institution in the Fall } 2016 \text { semester? } \\
\text { (Question for community college survey }\end{array}$} \\
\hline respondents only) & & (Table Continues) \\
\hline
\end{tabular}




\begin{tabular}{lll}
\hline Questionnaire Item & Community College Responses & Four-Year Institution Responses \\
\hline $0-100$ students & 1 & \\
$101-200$ students & 2 & \\
& 7 & \\
$201-500$ students & 0 & \\
$500-1,000$ students & 4 & \\
Over 1,000 students & 5 & \\
I don't know & & \\
What is the approximate number of & & \\
students who transfer to your institution & & \\
from a community college? (Question for & & \\
four-year institution respondents only) & & 3 \\
& & 2 \\
$0-100$ students & 7 \\
101-200 students & & 0 \\
201-500 students & & \\
Over 1,000 students & & \\
I don't know & & \\
\hline
\end{tabular}




\section{Responses by Sector}

As noted in Chapter Three, each questionnaire included a series of statements reflecting possible institutional actions that may help adult transfer students. The paired statement questions were worded in two different ways - "does reflect" and "should reflect." Respondents answered the first question on whether their higher education institution is currently offering a specific service for adult students. The second part of the paired question was answered by respondents on whether their higher education institution should be offering a specific service for adult students. Respondents indicated their responses on a five-point Likert scale. On the rating scale, " 1 " represented strong disagreement and " 5 " represented strong agreement. Neutral is represented by a rating of " 3 "; a rating above " 3 " would indicate at least some level of agreement while a rating below " 3 " would indicate at least some level of disagreement with the individual statements. Responses were collected to understand what transfer coordinators perceive is being done at their institutions to help adult students transfer as well as what should be done to help adult students transfer. The following paragraphs detail responses from community college transfer coordinators and from the transfer coordinators at four-year institutions.

\section{Community Colleges}

Table 4 shows the results for the statement pairs for community colleges. For every statement pair listed, all questionnaire items had mean responses over 3.0 for both "does reflect" and "should reflect" categories. This suggests that all survey items were deemed important by community college transfer coordinators, and that respondents perceive that all items represent actions that are currently undertaken at their respective higher education 
institutions and that should be undertaken. For example, the mean for the first statement (1a) "Students who are awarded credit at your college for learning in the military, on the job, or in other non-collegiate settings do find it easy to transfer those credits to four-year institutions" was 3.32 for the "does reflect" statement and 3.84 for the "should reflect" (1b) statement. On average, the respondents indicate that this statement reflects actual practice at their institutions and that awarding credit for learning in non-collegiate settings is a practice that should be undertaken. The difference, in the positive direction, between the "does reflect" (3.32) and "should reflect" ratings (3.84) might indicate that transfer coordinators hoped for an even greater effort in this area. This was the pattern for every item in the community college questionnaire; mean "should reflect" responses were in every case higher than mean "does reflect" statements. The description below shares analysis by survey themes. Those survey themes are articulation and credit transfer, curriculum and instruction, institutional goals and policies, and student services and advising.

Articulation and credit transfer. Most respondents agreed with each "should reflect" and "does reflect" statement concerning articulation and credit transfer (1a through 3b). Statement 1a ("Students who are awarded credit at your college for learning in the military, on the job, or in other non-collegiate settings do find it easy to transfer those credits to four-year institutions") received ratings of " 4 " or " 5 " from $52.6 \%$ of the respondents, which indicates agreement. The accompanying "should reflect" statement $1 b$ - received ratings of " 4 " or " 5 " from $68.5 \%$ of respondents, which also indicates agreement. An even higher percentage (79.0\%) issued ratings of " 4 " or " 5 " to statement 3a ("Articulation agreements are in place to help graduates of vocational programs [i.e., Associate of Applied Science graduates] transfer to 
four-year institutions. The corresponding "should reflect" statement (3b) received ratings of " 4 " or " 5 " from $100 \%$ of respondents, which also indicates strong agreement.

Curriculum and instruction. Respondents also agreed with statements 4a through 7b, which focused on curriculum and instruction. Statement 7a ("Our institution does encourage adult students to consider transferring and working towards a bachelor's degree") received ratings of " 4 " or " 5 " from $89.4 \%$ of the respondents, which indicates strong agreement. For the corresponding "should reflect" statement (7b), 94.8\% of the respondents issued ratings of " 4 " or "5" rating, which also indicates strong agreement.

Institutional goals and policies. For the institutional goals and policies statements (8a through 10b), all three of these paired statement sets received agreement from respondents. Specifically, statement 8a ("Our institution revisits academic policies and adjusts them to support adult students") received ratings of " 4 " or " 5 " from $52.6 \%$ of the respondents, which indicates agreement. For the corresponding "should reflect" statement (8b), $89.5 \%$ of the respondents issued ratings of " 4 " or " 5 " rating, which indicates strong agreement. Statement 10a ("Our institution does work with other colleges and universities across the state to improve services for adult students") received ratings of " 4 " or " 5 " from $57.9 \%$ of respondents, indicating agreement. The accompanying "should reflect" statement $10 \mathrm{~b}$-received ratings of " 4 " or " 5 " from $100 \%$ of respondents, also indicating agreement.

Student services and advising. The final set of statements (11a through 17b) found that while all of the paired statements indicated agreement, the paired statement that received the highest agreement from respondents was 16a ("Non-instructional staff at our institution do understand how working with adult learners may differ from working with younger, traditional 
students"). This statement received ratings of " 4 " or " 5 " from $83.3 \%$ of respondents, indicating strong agreement. For the corresponding "should reflect" statement, statement 16b, 100\% of respondents issued ratings of " 4 " or " 5 ," indicating strong agreement. 
Table 4

Mean and Distribution of Responses for "Does Reflect" and "Should Reflect" Statement Pairs, By Topic for Community College Respondents

\begin{tabular}{|c|c|c|c|c|c|c|c|c|}
\hline & Questionnaire items & 1 & 2 & 3 & 4 & 5 & $M$ & $N$ \\
\hline \multicolumn{9}{|c|}{ Articulation and credit transfer } \\
\hline $1 a$ & $\begin{array}{l}\text { Students who are awarded credit at your college for } \\
\text { learning in the military, on the job, or in other non- } \\
\text { collegiate settings do find it easy to transfer those } \\
\text { credits to four-year institutions. }\end{array}$ & $5.3 \%$ & $21.1 \%$ & $21.1 \%$ & $42.1 \%$ & $10.5 \%$ & 3.32 & 19 \\
\hline $1 b$ & $\begin{array}{l}\text { Students who are awarded credit at your college for } \\
\text { learning in the military, on the job, or in other non- } \\
\text { collegiate settings should find it easy to transfer those } \\
\text { credits to four-year institutions. }\end{array}$ & $0.0 \%$ & $5.3 \%$ & $26.3 \%$ & $47.4 \%$ & $21.1 \%$ & 3.84 & 19 \\
\hline $2 a$ & $\begin{array}{l}\text { Articulation agreements are as helpful to adult students } \\
\text { who come to the community college with a variety of } \\
\text { credits previously earned at other institutions, as they } \\
\text { are for younger students who enroll at the community } \\
\text { college immediately after high school. }\end{array}$ & $0.0 \%$ & $21.1 \%$ & $5.3 \%$ & $42.1 \%$ & $31.6 \%$ & 3.32 & 19 \\
\hline $2 b$ & $\begin{array}{l}\text { Articulation agreements should be as helpful to adult } \\
\text { students who come to the community college with a } \\
\text { variety of credits previously earned at other } \\
\text { institutions, as they are for younger students who enroll }\end{array}$ & $0.0 \%$ & $5.3 \%$ & $15.8 \%$ & $36.8 \%$ & $42.1 \%$ & 3.84 & $\begin{array}{r}19 \\
\text { (Table } \\
\text { Continues) }\end{array}$ \\
\hline
\end{tabular}




\begin{tabular}{|c|c|c|c|c|c|c|c|c|}
\hline & Questionnaire items & 1 & 2 & 3 & 4 & 5 & $M$ & $N$ \\
\hline & \multicolumn{8}{|l|}{$\begin{array}{l}\text { at the community college immediately after high } \\
\text { school. }\end{array}$} \\
\hline $3 a$ & $\begin{array}{l}\text { Articulation agreements are in place to help graduates } \\
\text { of vocational programs (i.e., Associate of Applied } \\
\text { Science graduates) transfer to four-year institutions. }\end{array}$ & $5.3 \%$ & $15.8 \%$ & $0.0 \%$ & $47.4 \%$ & $31.6 \%$ & 3.84 & 19 \\
\hline $3 b$ & $\begin{array}{l}\text { Articulation agreements should be in place to help } \\
\text { graduates of vocational programs (i.e., Associate of } \\
\text { Applied Science graduates) transfer to four-year } \\
\text { institutions. }\end{array}$ & $0.0 \%$ & $0.0 \%$ & $0.0 \%$ & $57.9 \%$ & $42.1 \%$ & 4.16 & 19 \\
\hline \multicolumn{9}{|c|}{ Curriculum and instruction } \\
\hline $4 a$ & $\begin{array}{l}\text { Our college does have an arrangement with four-year } \\
\text { institutions to provide bachelor's degree completion } \\
\text { programs for place-bound associate degree graduates, } \\
\text { either through online study or through partnerships } \\
\text { whereby the four-year college brings upper-division } \\
\text { courses to our local area. }\end{array}$ & $5.3 \%$ & $15.8 \%$ & $0.0 \%$ & $42.1 \%$ & $36.8 \%$ & 3.89 & 19 \\
\hline $4 b$ & $\begin{array}{l}\text { Our college should have an arrangement with four-year } \\
\text { institutions to provide bachelor's degree completion } \\
\text { programs for place-bound associate degree graduates, } \\
\text { either through online study or through partnerships } \\
\text { whereby the four-year college brings upper-division } \\
\text { courses to our local area. }\end{array}$ & $0.0 \%$ & $0.0 \%$ & $5.3 \%$ & $36.8 \%$ & $57.9 \%$ & 4.53 & $\begin{array}{r}19 \\
\text { (Table } \\
\text { Continues) }\end{array}$ \\
\hline
\end{tabular}




\begin{tabular}{|c|c|c|c|c|c|c|c|c|}
\hline & Questionnaire items & 1 & 2 & 3 & 4 & 5 & $M$ & $N$ \\
\hline $5 a$ & $\begin{array}{l}\text { Faculty at our institution do understand how teaching } \\
\text { adult learners may differ from teaching younger, } \\
\text { traditional students. }\end{array}$ & $5.3 \%$ & $15.8 \%$ & $21.1 \%$ & $36.8 \%$ & $21.1 \%$ & 3.53 & 19 \\
\hline $5 b$ & $\begin{array}{l}\text { Faculty at our institution should understand how } \\
\text { teaching adult learners may differ from teaching } \\
\text { younger, traditional students. }\end{array}$ & $0.0 \%$ & $0.0 \%$ & $0.0 \%$ & $36.8 \%$ & $63.2 \%$ & 4.63 & 19 \\
\hline $6 a$ & $\begin{array}{l}\text { Our college does offer courses at convenient times and } \\
\text { places that accommodate students with extensive job } \\
\text { and family obligations. }\end{array}$ & $5.3 \%$ & $5.3 \%$ & $10.5 \%$ & $63.2 \%$ & $15.8 \%$ & 3.79 & 19 \\
\hline $6 b$ & $\begin{array}{l}\text { Our college should offer courses at convenient times } \\
\text { and places that accommodate students with extensive } \\
\text { job and family obligations. }\end{array}$ & $0.0 \%$ & $0.0 \%$ & $5.3 \%$ & $52.6 \%$ & $42.1 \%$ & 4.37 & 19 \\
\hline $7 a$ & $\begin{array}{l}\text { Our institution does encourage adult students to } \\
\text { consider transferring and working towards a bachelor's } \\
\text { degree. }\end{array}$ & $5.3 \%$ & $0.0 \%$ & $5.3 \%$ & $36.8 \%$ & $52.6 \%$ & 4.32 & 19 \\
\hline $7 b$ & $\begin{array}{l}\text { Our institution should encourage adult students to } \\
\text { consider transferring and working towards a bachelor's } \\
\text { degree. }\end{array}$ & $0.0 \%$ & $0.0 \%$ & $5.3 \%$ & $31.6 \%$ & $63.2 \%$ & 4.58 & 19 \\
\hline Institut & nal goals and policy & & & & & & & \\
\hline $8 a$ & $\begin{array}{l}\text { Our institution revisits academic policies and adjusts } \\
\text { them to support adult students. }\end{array}$ & $0.0 \%$ & $26.3 \%$ & $21.1 \%$ & $42.1 \%$ & $10.5 \%$ & 3.37 & $\begin{array}{r}19 \\
\text { (Table } \\
\text { tinues) }\end{array}$ \\
\hline
\end{tabular}




\begin{tabular}{|c|c|c|c|c|c|c|c|c|}
\hline & Questionnaire items & 1 & 2 & 3 & 4 & 5 & $M$ & $N$ \\
\hline $8 b$ & $\begin{array}{l}\text { Our institution should revisit academic policies and } \\
\text { adjusts them to support adult students. }\end{array}$ & $0.0 \%$ & $0.0 \%$ & $10.5 \%$ & $57.9 \%$ & $31.6 \%$ & 4.21 & 19 \\
\hline $9 a$ & $\begin{array}{l}\text { Recruiting adult students is a high priority at our } \\
\text { institution. }\end{array}$ & $5.3 \%$ & $21.1 \%$ & $15.8 \%$ & $36.8 \%$ & $21.1 \%$ & 3.47 & 19 \\
\hline $9 b$ & $\begin{array}{l}\text { Recruiting adult students should be a high priority at } \\
\text { our institution. }\end{array}$ & $0.0 \%$ & $0.0 \%$ & $5.3 \%$ & $42.1 \%$ & $52.6 \%$ & 4.47 & 19 \\
\hline $10 a$ & $\begin{array}{l}\text { Our institution does work with other colleges and } \\
\text { universities across the state to improve services for } \\
\text { adult students. }\end{array}$ & $0.0 \%$ & $26.3 \%$ & $15.8 \%$ & $52.6 \%$ & $5.3 \%$ & 3.37 & 19 \\
\hline $10 b$ & Our institution should work with other colleges and & $0.0 \%$ & $0.0 \%$ & $0.0 \%$ & $63.2 \%$ & $36.8 \%$ & 4.37 & 19 \\
\hline
\end{tabular}
universities across the state to improve services for adult students.

Student services and advising

11a Orientation programs for students at our college are as helpful to adult students in making them feel welcome and part of the institutional culture as they are for younger, traditional students.

11b Orientation programs for students at our college should be as helpful to adult students in making them feel welcome and part of the institutional culture as they are for younger, traditional students. 


\section{2a Adult students at our community college do feel as} welcome as younger, traditional students.

12b Adult students at our community college should feel as welcome as younger, traditional students.

13a Adult students do have opportunities to become involved in campus life at our institution.

13b Adult students should have opportunities to become involved in campus life at our institution.

14a Our institution does provide support services geared specifically for adult students who plan to transfer.

14b Our institution should provide support services geared specifically for adult students who plan to transfer.

15a Advising and other support services are designed to prepare students for successful transfer to four-year institutions and are offered at times (or in online formats) that are convenient for working adults.

15b Advising and other support services should be designed to prepare students for successful transfer to four-year institutions and are offered at times (or in online formats) that are convenient for working adults.

16a Non-instructional staff at our institution do understand how working with adult learners may differ from working with younger, traditional students.

\begin{tabular}{|c|c|c|c|c|c|c|}
\hline 1 & 2 & 3 & 4 & 5 & $M$ & $N$ \\
\hline $0.0 \%$ & $11.1 \%$ & $50.0 \%$ & $33.3 \%$ & $5.6 \%$ & 3.33 & 18 \\
\hline $0.0 \%$ & $0.0 \%$ & $0.0 \%$ & $50.0 \%$ & $50.0 \%$ & 4.50 & 18 \\
\hline $0.0 \%$ & $0.0 \%$ & $0.0 \%$ & $72.2 \%$ & $27.8 \%$ & 4.28 & 18 \\
\hline $0.0 \%$ & $0.0 \%$ & $0.0 \%$ & $50.0 \%$ & $50.0 \%$ & 4.50 & 18 \\
\hline $0.0 \%$ & $27.8 \%$ & $33.3 \%$ & $33.3 \%$ & $5.6 \%$ & 3.17 & 18 \\
\hline $0.0 \%$ & $0.0 \%$ & $11.1 \%$ & $50.0 \%$ & $38.9 \%$ & 4.28 & 18 \\
\hline $0.0 \%$ & $16.7 \%$ & $5.6 \%$ & $55.6 \%$ & $22.2 \%$ & 3.83 & 18 \\
\hline $0.0 \%$ & $0.0 \%$ & $0.0 \%$ & $44.4 \%$ & $55.6 \%$ & 4.56 & 18 \\
\hline $0.0 \%$ & $5.6 \%$ & $11.1 \%$ & $61.1 \%$ & $22.2 \%$ & 4.00 & $\begin{array}{r}18 \\
\text { (Table } \\
\text { tinues) }\end{array}$ \\
\hline
\end{tabular}




\section{Questionnaire items}

16b Non-instructional staff at our institution should understand how working with adult learners may differ from working with younger, traditional students.

17a Our community college does know that adult students at our institution do not always treat higher education as a priority.

17b Our community college should know that adult students at our institution do not always treat higher education as a priority. $\begin{array}{lllllll}0.0 \% & 0.0 \% & 0.0 \% & 55.6 \% & 44.4 \% & 4.44 & 18\end{array}$

$\begin{array}{llllll}0.0 \% & 16.7 \% & 22.2 \% & 33.3 \% & 27.8 \% & 3.72\end{array}$

18

$\begin{array}{llllll}0.0 \% & 0.0 \% & 22.2 \% & 38.9 \% & 38.9 \% & 4.16\end{array}$

18 
Table 5 rank orders (from largest to smallest) statements from the community college questionnaire in terms of the difference between mean difference "does reflect" responses and mean "should reflect" responses. This answers the third research question for the community college sector, pointing to potential gaps between what is being done at the community colleges to help adult transfer students and what should be done. Those items that yielded a gap of " 1 " or more will be highlighted, because these reflect areas that, in the opinion of respondents, the institutions need to improve. These items are organized by survey themes.

Articulation and credit transfer. This theme did not have any statements that yielded a gap of " 1 " or more, indicating concern.

Curriculum and instruction. A potential concern reflected in the responses of community college coordinators (with a mean difference of 1.1 ) is the possibility that faculty may not understand how teaching adult students differs from teaching traditional students.

Institutional goals and policies. A probable concern found within the institutional goals and policies survey theme (with a mean difference of 1 ) is that community college transfer coordinators feel their institution may not work with other colleges and universities across the state to improve services for adult students.

Another concern of community college transfer coordinators (with a mean difference of 1) is the possibility that recruiting adult students to community colleges may not be a high priority. This finding is rather interesting, since community colleges have traditionally worked with adult students to help them complete their education.

Student services and advising. Interestingly, the respondents perceive that their institutions may not be as accommodating to adult students as they should be, as evidenced in 
the somewhat large gap between the perception of what is happening at community colleges and the perception of what should be happening at community colleges (a mean difference of 1.17). This is a rather surprising finding given the long-standing reputation that community colleges have in working with adult students.

In addition to the concern about making community colleges more welcoming to adult students, community college survey respondents perceive that their institutions may need to provide additional support services specifically designed for adult students who plan to transfer (a mean difference of 1.11). The need for specially designed services reflects the unique circumstances of adult students, who, unlike their younger counterparts, cannot devote their full attention to academic pursuits.

Another possible concern reflected in the responses is that orientations for students at their colleges may not be as helpful for adult students in making them feel welcome and part of the institutional culture as they are for younger, traditional students (a mean difference of 1.05). Orientations for students can likely be created with the traditional student in mind.

These six concerns have been noted because they may provide a window where readers can see possible shortfalls happening at community colleges in their efforts to help adult students transfer successfully. 
Table 5

Community College Questionnaire Items Rank Ordered by The Difference Between What Is and What Should be Done for Adult Transfer Students

\begin{tabular}{|c|c|c|c|c|c|}
\hline Topical areas most relevant to the questions & $\begin{array}{c}\text { Mean } \\
\text { difference } \\
\text { between what } \\
\text { is and what } \\
\text { should be }\end{array}$ & $\begin{array}{l}\text { Articulation } \\
\text { and credit } \\
\text { transfer }\end{array}$ & $\begin{array}{l}\text { Curriculum } \\
\text { and } \\
\text { instruction }\end{array}$ & $\begin{array}{l}\text { Institutional } \\
\text { goals and } \\
\text { policy }\end{array}$ & $\begin{array}{c}\text { Student services } \\
\text { and advising }\end{array}$ \\
\hline $\begin{array}{l}\text { Adult students at our community college } \\
\text { do/should feel as welcome as younger, traditional } \\
\text { students. }\end{array}$ & 1.17 & & & & $\mathrm{x}$ \\
\hline $\begin{array}{l}\text { Our institution does/should provide support } \\
\text { services geared specifically for adult students who } \\
\text { plan to transfer. }\end{array}$ & 1.11 & & & & $x$ \\
\hline $\begin{array}{l}\text { Faculty at our institution do/should understand } \\
\text { how teaching adult learners may differ from } \\
\text { teaching younger, traditional students. }\end{array}$ & 1.1 & & $x$ & & \\
\hline $\begin{array}{l}\text { Our institution does/should work with other } \\
\text { colleges and universities across the state to } \\
\text { improve services for adult students. }\end{array}$ & 1 & & & $x$ & $\begin{array}{r}\text { (Table } \\
\text { Continues) }\end{array}$ \\
\hline
\end{tabular}




\begin{tabular}{|c|c|c|c|c|c|}
\hline Topical areas most relevant to the questions & $\begin{array}{c}\text { Mean } \\
\text { difference } \\
\text { between what } \\
\text { is and what } \\
\text { should be }\end{array}$ & $\begin{array}{l}\text { Articulation } \\
\text { and credit } \\
\text { transfer }\end{array}$ & $\begin{array}{l}\text { Curriculum } \\
\text { and } \\
\text { instruction }\end{array}$ & $\begin{array}{c}\text { Institutional } \\
\text { goals and } \\
\text { policy }\end{array}$ & $\begin{array}{c}\text { Student services } \\
\text { and advising }\end{array}$ \\
\hline
\end{tabular}

Recruiting adult students is/should be a high

Our institution does/should revisit academic

policies and adjust them to support adult students.

Advising and other support services are/should be

designed to prepare students for successful transfer to four-year institutions and are offered at times (or in online formats) that are convenient for working adults.

Our college does/should have an arrangement with four-year institutions to provide bachelor's degree completion programs for place-bound associate's degree graduates, either through online study or through partnerships whereby the four-year college brings upper-division courses to our local area.

Our college does/should offer courses at 


\begin{tabular}{ccccc}
\hline Topical areas most relevant to the questions & $\begin{array}{c}\text { Mean } \\
\text { difference } \\
\text { between what } \\
\text { is and what } \\
\text { should be }\end{array}$ & $\begin{array}{c}\text { Articulation } \\
\text { transfer credit }\end{array}$ & $\begin{array}{c}\text { Curriculum and instruction } \\
\text { anditutional }\end{array}$ & $\begin{array}{c}\text { Student services } \\
\text { goals and } \\
\text { policy advising }\end{array}$ \\
& & & \\
\hline
\end{tabular}

Students who are awarded credit at your college for learning in the military, on the job, or in other non-collegiate settings do/should find it easy to transfer those credits to four-year institutions.

Articulation agreements are/should be as helpful to adult students who come to the community college with a variety of credits previously earned at other institutions, as they are for younger students who enroll at the community college immediately after high school.

Our community college does/should know that adult students at our institution do not always treat higher education as a priority. 


\begin{tabular}{|c|c|c|c|c|c|}
\hline Topical areas most relevant to the questions & $\begin{array}{l}\text { Mean } \\
\text { difference } \\
\text { between what } \\
\text { is and what } \\
\text { should be }\end{array}$ & $\begin{array}{l}\text { Articulation } \\
\text { and credit } \\
\text { transfer }\end{array}$ & $\begin{array}{l}\text { Curriculum } \\
\text { and } \\
\text { instruction }\end{array}$ & $\begin{array}{l}\text { Institutional } \\
\text { goals and } \\
\text { policy }\end{array}$ & $\begin{array}{l}\text { Student services } \\
\text { and advising }\end{array}$ \\
\hline $\begin{array}{l}\text { Non-instructional staff at our institution } \\
\text { do/should understand how working with adult } \\
\text { learners may differ from working with younger, } \\
\text { traditional students. }\end{array}$ & 0.44 & & & & $x$ \\
\hline $\begin{array}{l}\text { Articulation agreements are/should be in place to } \\
\text { help graduates of vocational programs (i.e., } \\
\text { Associate of Applied Science graduates) transfer } \\
\text { to four-year institutions. }\end{array}$ & 0.32 & $x$ & & & \\
\hline $\begin{array}{l}\text { Adult students do have opportunities to become } \\
\text { involved in campus life at out institution. }\end{array}$ & 0.22 & & & & $x$ \\
\hline
\end{tabular}




\section{Four-Year Institution Survey Results}

In the four-year institution survey, the majority of the "does reflect" and "should reflect" statements had mean responses over 3.0. This suggests that these survey items were deemed important by four-year institution transfer coordinators. It also suggests that these statements were true in practice ("does reflect") and that the transfer coordinators felt they reflected appropriate steps that colleges should take in working with adult transfer students ("should reflect").

However, the respondents from four-year colleges raised concerns that current practice at their institutions may be insufficient. This can be seen in Table 6 in the six statements that received mean rankings of less than " 3 " when the transfer coordinators were asked about their agreement on what is being done at their institutions.

Two survey items within the articulation and credit transfer dimensions had mean rankings of less than 3 . Those were "Community college students who have earned credits for learning in the military, on the job, or in other non-collegiate settings do find it easy to transfer those credits to your institution" (with a mean ranking of 2.93) and "Articulation agreements are in place to help graduates of vocational programs (i.e., Associate of Applied Science graduates) transfer to our institution" (with a mean ranking of 2.87).

Two survey items within the curriculum and instruction transfer dimensions also had mean rankings of less than 3. Those were "Our institution does provide bachelor's degree completion programs for place-bound community college graduates, either through online study or by bringing upper-division courses to the community colleges" (with a mean ranking of 
2.60) and "Our institution does offer courses at convenient times and places that accommodate students with extensive job and family obligations" (with a mean ranking of 2.73 ).

Finally, two survey items within the institutional goals and policies dimensions also had mean rankings of less than 3 . Those statements were "Our institution revisits academic policies and adjusts them to support adult students" (with a mean ranking of 2.67) and "Our institution does work with other colleges and universities across the state to improve services for adult students" (with a mean ranking of 2.87). 
Results for statement pairs in each of the four dimensions are briefly summarized below.

Articulation and credit transfer. For the articulation and credit transfer paired statements ( $1 a$ through $3 b$ ) statements $1 a, 1 b$ and $3 a, 3 b$ show disagreement between the "does reflect" pairs and the accompanying "should reflect" statements. Although four-year institution transfer coordinators agree with the statement ("Community college students who have earned credits for learning in the military, on the job, or in other non-collegiate settings should find it easy to transfer those credits to your institution") with a mean ranking of 3.47, the "does reflect" statement ("Community college students who have earned credits for learning in the military, on the job, or in other non-collegiate settings do find it easy to transfer those credits to your institution") received a mean ranking of 2.93 indicating disagreement. Statement 1 a received ratings of " 1 " and " 2 " from $40 \%$ of respondents, indicating disagreement. The statement also received ratings of " 4 " and" 5 " from $40 \%$ of the respondents, indicating agreement.

Statement 3a ("Articulation agreements are in place to help graduates of vocational programs [i.e., Associate of Applied Science graduates] transfer to our institution"), shows disagreement between the "does reflect" statement and the accompanying "should reflect" statement. Four-year transfer coordinators agree with the "should reflect" statement (3b), with a mean ranking of 3.73. For the "does reflect" statement, it is interesting to see that it received ratings of " 1 " and " 2 " from $40 \%$ of respondents indicating disagreement. The statement also received ratings of " 4 " and " 5 " from $40 \%$ of the respondents, indicating agreement. 
Curriculum and instruction. Of the paired statements related to curriculum and instruction (4a through 7b), statements $4 a, 4 b, 6 a$ and $6 b$ show disagreement between the "does reflect" and the accompanying "should reflect" versions. Although four-year institution transfer coordinators agree that their institution should provide bachelor's degree completion programs for place-bound community college graduates, either through online study or by bringing upper-division courses to the community colleges (with a mean ranking of 3.79), the "does reflect" statement for this question ("Our institution does provide bachelor's degree completion programs for place-bound community college graduates, either through online study or by bringing upper-division courses to the community colleges") received a mean ranking of 2.60, indicating disagreement. The "does reflect" statement received ratings of "1" and " 2 " from $46.6 \%$ of respondents, indicating disagreement.

Statement 6b ("Our college should offer courses at convenient times and places that accommodate students with extensive job and family obligations") received a mean ranking of 3.93, indicating agreement, while the "does reflect" 6a statement ("Our institution does provide bachelor's degree completion programs for place-bound community college graduates, either through online study or by bringing upper-division courses to the community colleges" received a mean ranking of 2.73 , indicating disagreement. The "does reflect" statement received ratings of " 1 " and " 2 " from $60 \%$ of respondents, indicating disagreement.

Institutional goals and policy. Within the institutional goals and policy paired statements ( $8 a$ through $11 b$ ), statements $8 a, 8 b, 11 a$, and $11 b$ show disagreement between the "does reflect" pairs and the "should reflect" statements. Statement 8b ("Our institution should revisit academic policies and adjust them to support adult students") received a mean ranking 
of 3.67, indicating agreement, while the "does reflect" 8a statement for this question ("Our institution does revisit academic policies and adjusts them to support adult students") received a mean ranking of 2.67 , indicating disagreement. The "does reflect" statement received ratings of " 1 " and " 2 " from $40 \%$ of respondents, indicating disagreement.

Statement 11b ("Our institution should work with other colleges and universities across the state to improve services for adult students") received a mean ranking of 3.93, indicating agreement, while the "does reflect" 11 a statement ("Our institution does work with other colleges and universities across the state to improve services for adult students") received a mean ranking of 2.87 , indicating disagreement. The "does reflect" statement received ratings of " 1 " and " 2 " from $40 \%$ of respondents, indicating disagreement.

Student services and advising. Within the student services and advising paired statements (12a to $18 \mathrm{~b})$, all statements had mean rankings of 3.0 or higher, indicating agreement with both the "does reflect" and "should reflect" categories. This suggests that respondents perceive that all items within this dimension are actions that are currently undertaken at their respective higher education institutions and should be undertaken. 
Table 6

Mean and Distribution of Responses for "Does Reflect" and "Should Reflect" Statement Pairs, by Topic for Four-year College Respondents

\begin{tabular}{|c|c|c|c|c|c|c|c|c|}
\hline & \multirow[t]{2}{*}{ Questionnaire items } & \multicolumn{5}{|c|}{ Responses (\% in each category) } & \multirow[b]{2}{*}{$M$} & \multirow[b]{2}{*}{$N$} \\
\hline & & 1 & 2 & 3 & 4 & 5 & & \\
\hline \multicolumn{9}{|c|}{ Articulation and credit transfer } \\
\hline $1 a$ & $\begin{array}{l}\text { Community college students who have earned } \\
\text { credits for learning in the military, on the job, or in } \\
\text { other non-collegiate settings do find it easy to } \\
\text { transfer those credits to your institution. }\end{array}$ & $13.3 \%$ & $26.7 \%$ & $20.0 \%$ & $33.3 \%$ & $6.7 \%$ & 2.93 & 15 \\
\hline $1 b$ & $\begin{array}{l}\text { Community college students who have earned } \\
\text { credits for learning in the military, on the job, or in } \\
\text { other non-collegiate settings should find it easy to } \\
\text { transfer those credits to your institution. }\end{array}$ & $6.7 \%$ & $20.0 \%$ & $13.3 \%$ & $40.0 \%$ & $20.0 \%$ & 3.47 & 15 \\
\hline $2 a$ & $\begin{array}{l}\text { Articulation agreements are as helpful to adult } \\
\text { students who come to the community college with a } \\
\text { variety of credits previously earned at other } \\
\text { institutions, as they are for younger students who } \\
\text { enroll at the community college immediately after } \\
\text { high school. }\end{array}$ & $13.3 \%$ & $26.7 \%$ & $6.7 \%$ & $26.7 \%$ & $26.7 \%$ & 3.27 & $\begin{array}{r}\text { (Table } \\
\text { Continues) }\end{array}$ \\
\hline
\end{tabular}




\begin{tabular}{|c|c|c|c|c|c|c|c|c|}
\hline & \multirow[t]{2}{*}{ Questionnaire items } & \multicolumn{5}{|c|}{ Responses (\% in each category) } & \multirow[b]{2}{*}{$M$} & \multirow[b]{2}{*}{$N$} \\
\hline & & 1 & 2 & 3 & 4 & 5 & & \\
\hline $2 b$ & $\begin{array}{l}\text { Articulation agreements should be as helpful to } \\
\text { adult students who come to the community college } \\
\text { with a variety of credits previously earned at other } \\
\text { institutions, as they are for younger students who } \\
\text { enroll at the community college immediately after } \\
\text { high school. }\end{array}$ & $14.3 \%$ & $0.0 \%$ & $21.4 \%$ & $14.3 \%$ & $50.0 \%$ & 3.86 & 15 \\
\hline $3 a$ & $\begin{array}{l}\text { Articulation agreements are in place to help } \\
\text { graduates of vocational programs (i.e., Associate of } \\
\text { Applied Science graduates) transfer to our } \\
\text { institution. }\end{array}$ & $20.0 \%$ & $20.0 \%$ & $20.0 \%$ & $33.3 \%$ & $6.7 \%$ & 2.87 & 15 \\
\hline $3 b$ & $\begin{array}{l}\text { Articulation agreements should be in place to help } \\
\text { graduates of vocational programs (i.e., Associate of } \\
\text { Applied Science graduates) transfer to our } \\
\text { institution. }\end{array}$ & $0.0 \%$ & $6.7 \%$ & $26.7 \%$ & $53.3 \%$ & $13.3 \%$ & 3.73 & 15 \\
\hline \multicolumn{9}{|c|}{ Curriculum and instruction } \\
\hline $4 a$ & $\begin{array}{l}\text { Our institution does provide bachelor's degree } \\
\text { completion programs for place-bound community } \\
\text { college graduates, either through online study or by } \\
\text { bringing upper-division courses to the community } \\
\text { colleges. }\end{array}$ & $33.3 \%$ & $13.3 \%$ & $20.0 \%$ & $26.7 \%$ & $6.7 \%$ & 2.60 & 14 \\
\hline $4 b$ & $\begin{array}{l}\text { Our institution should provide bachelor's degree } \\
\text { completion programs for place-bound community } \\
\text { college graduates, either through online study or by }\end{array}$ & $0.0 \%$ & $7.1 \%$ & $21.4 \%$ & $57.1 \%$ & $14.3 \%$ & 3.79 & $\begin{array}{r}15 \\
\text { (Table } \\
\text { Continues) }\end{array}$ \\
\hline
\end{tabular}




Questionnaire items Responses (\% in each category)

bringing upper-division courses to the community

colleges.

5a Faculty at our institution do understand how teaching adult learners may differ from teaching younger, traditional students.

5b Faculty at our institution should understand how teaching adult learners may differ from teaching younger, traditional students.

6a Our college does offer courses at convenient times and places that accommodate students with extensive job and family obligations.

6b Our college should offer courses at convenient times and places that accommodate students with extensive job and family obligations.

7a Our institution does have a general studies or an interdisciplinary bachelor's degree program designed specifically for adult students.

7b Our institution should have a general studies or an interdisciplinary bachelor's degree program

1 2 3 4 5 M

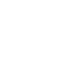
designed specifically for adult students.

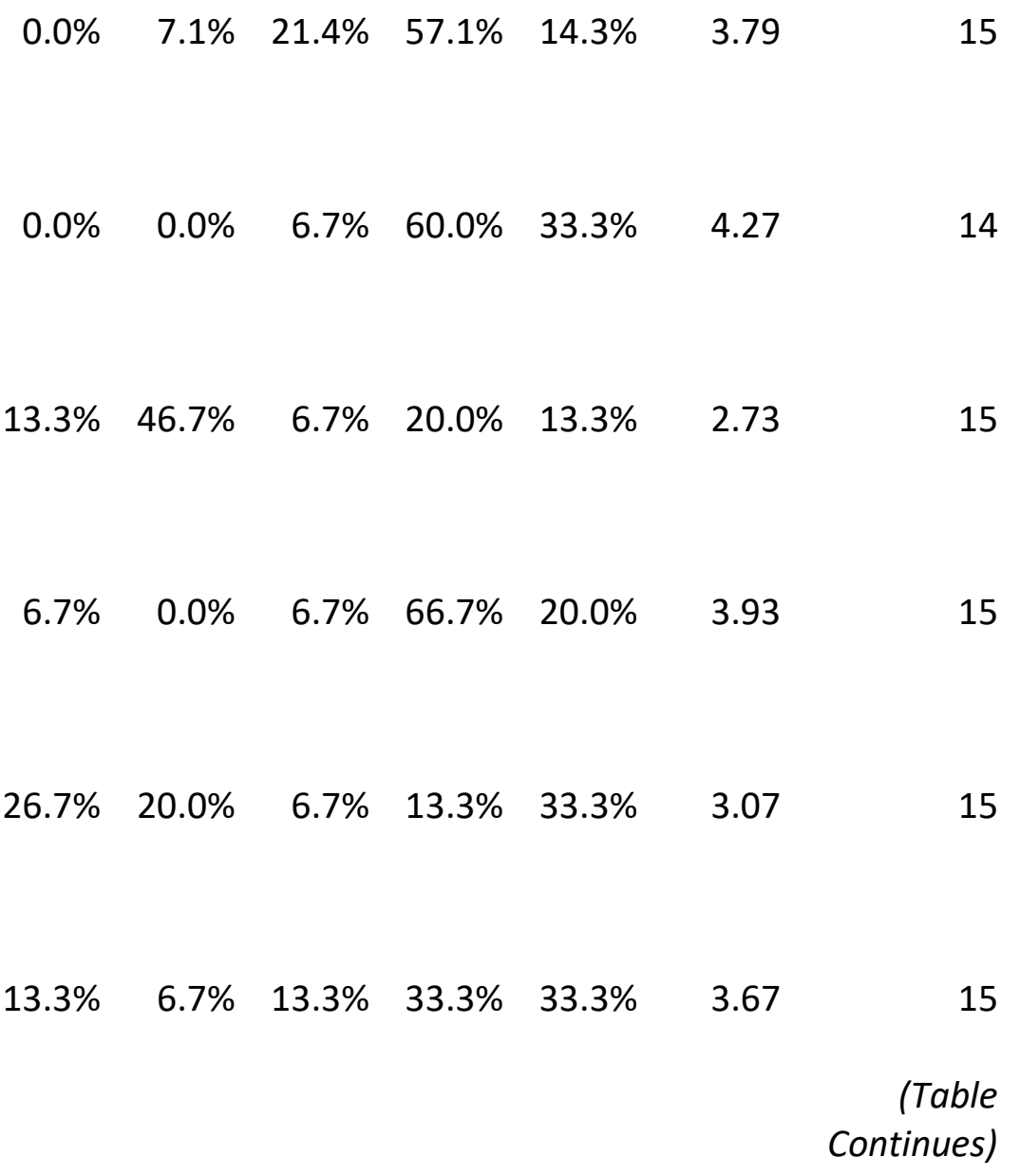




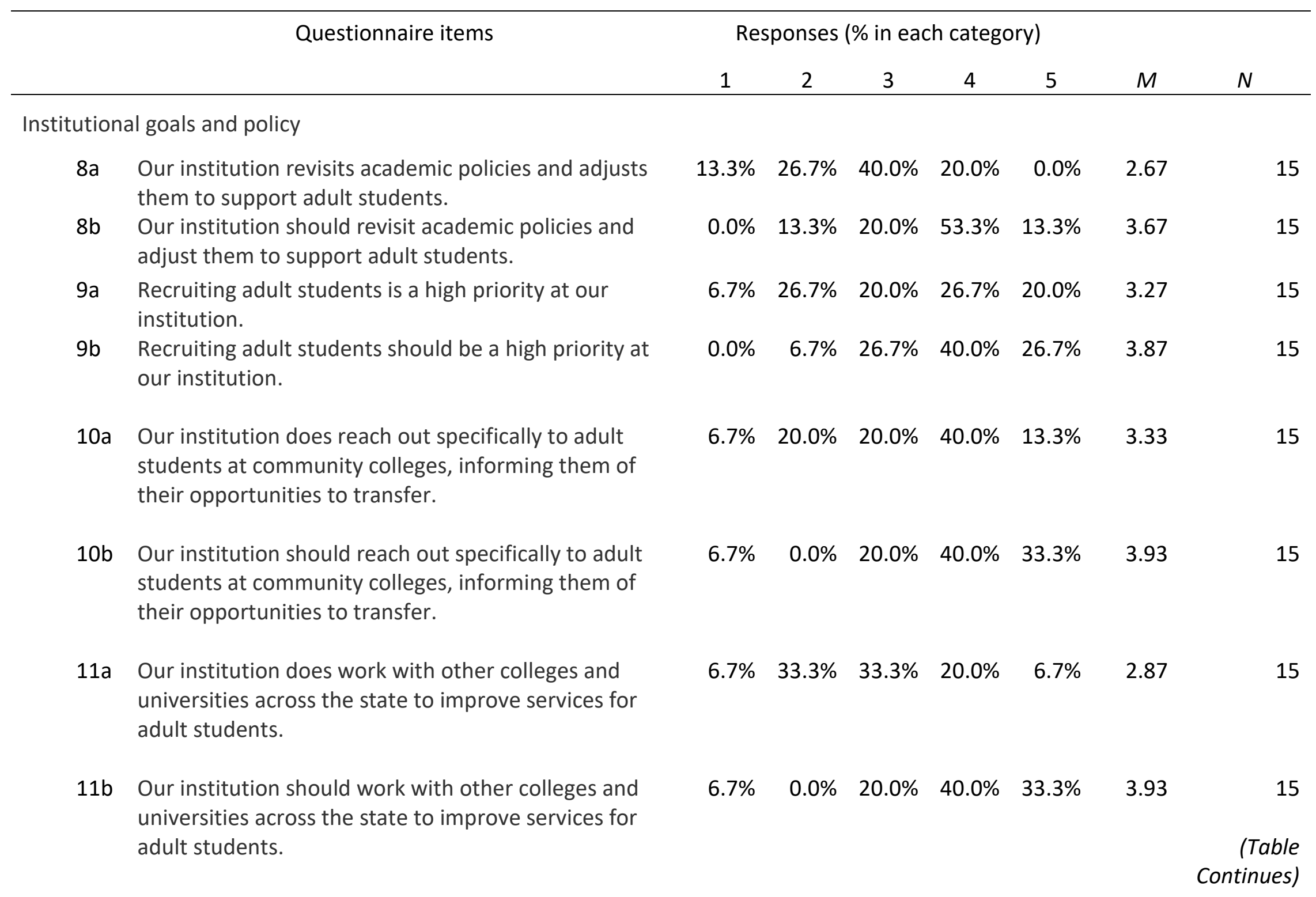

Student services and advising 


\begin{tabular}{|c|c|c|c|c|c|c|c|c|}
\hline & \multirow[t]{2}{*}{ Questionnaire items } & \multicolumn{5}{|c|}{ Responses (\% in each category) } & \multirow[b]{2}{*}{$M$} & \multirow[b]{2}{*}{$N$} \\
\hline & & 1 & 2 & 3 & 4 & 5 & & \\
\hline $12 a$ & $\begin{array}{l}\text { Orientation programs for new transfer students at } \\
\text { our institution are as helpful to adult students in } \\
\text { making them feel welcome and part of the } \\
\text { institutional culture as they are for younger, } \\
\text { traditional students. }\end{array}$ & $0.0 \%$ & $35.7 \%$ & $14.3 \%$ & $42.9 \%$ & $7.1 \%$ & 3.21 & 14 \\
\hline $12 b$ & $\begin{array}{l}\text { Orientation programs for new transfer students at } \\
\text { our institution should be as helpful to adult students } \\
\text { in making them feel welcome and part of the } \\
\text { institutional culture as they are for younger, } \\
\text { traditional students. }\end{array}$ & $0.0 \%$ & $0.0 \%$ & $7.1 \%$ & $57.1 \%$ & $35.7 \%$ & 4.29 & 14 \\
\hline $13 a$ & $\begin{array}{l}\text { Adult students transferring to our institution from } \\
\text { community colleges do feel as welcome as younger } \\
\text { students transferring from community colleges. }\end{array}$ & $0.0 \%$ & $14.3 \%$ & $57.1 \%$ & $28.6 \%$ & $0.0 \%$ & 3.14 & 14 \\
\hline $13 b$ & $\begin{array}{l}\text { Adult students transferring to our institution from } \\
\text { community colleges should feel as welcome as } \\
\text { younger students transferring from community } \\
\text { colleges. }\end{array}$ & $0.0 \%$ & $0.0 \%$ & $0.0 \%$ & $71.4 \%$ & $28.6 \%$ & 4.29 & 14 \\
\hline $14 a$ & $\begin{array}{l}\text { Adult students transferring to our institution do } \\
\text { have opportunities to become involved in campus } \\
\text { life. }\end{array}$ & $0.0 \%$ & $7.7 \%$ & $23.1 \%$ & $46.2 \%$ & $23.1 \%$ & 3.85 & 13 \\
\hline $14 b$ & $\begin{array}{l}\text { Adult students transferring to our institution should } \\
\text { have opportunities to become involved in campus } \\
\text { life. }\end{array}$ & $0.0 \%$ & $0.0 \%$ & $0.0 \%$ & $57.1 \%$ & $42.9 \%$ & 4.43 & $\begin{array}{r}14 \\
\text { (Table } \\
\text { Continues) }\end{array}$ \\
\hline
\end{tabular}




\begin{tabular}{|c|c|c|c|c|c|c|c|c|}
\hline & \multirow[t]{2}{*}{ Questionnaire items } & \multicolumn{5}{|c|}{ Responses (\% in each category) } & \multirow[b]{2}{*}{$M$} & \multirow[b]{2}{*}{$N$} \\
\hline & & 1 & 2 & 3 & 4 & 5 & & \\
\hline $15 a$ & $\begin{array}{l}\text { Our institution does provide support services geared } \\
\text { specifically for adult students transferring from } \\
\text { community colleges. }\end{array}$ & $0.0 \%$ & $28.6 \%$ & $14.3 \%$ & $42.9 \%$ & $14.3 \%$ & 3.43 & 14 \\
\hline $15 b$ & $\begin{array}{l}\text { Our institution should provide support services } \\
\text { geared specifically for adult students transferring } \\
\text { from community colleges. }\end{array}$ & $0.0 \%$ & $0.0 \%$ & $14.3 \%$ & $42.9 \%$ & $42.9 \%$ & 4.29 & 14 \\
\hline $16 a$ & $\begin{array}{l}\text { Advising and other support services are designed to } \\
\text { help students transferring from community colleges } \\
\text { and are offered at times (or in online formats) that } \\
\text { are convenient for adult working students. }\end{array}$ & $14.3 \%$ & $21.4 \%$ & $7.1 \%$ & $35.7 \%$ & $21.4 \%$ & 3.29 & 14 \\
\hline $16 b$ & $\begin{array}{l}\text { Advising and other support services should be } \\
\text { designed to help students transferring from } \\
\text { community colleges and are offered at times (or in } \\
\text { online formats) that are convenient for adult } \\
\text { working students. }\end{array}$ & $0.0 \%$ & $0.0 \%$ & $7.1 \%$ & $50.0 \%$ & $42.9 \%$ & 4.36 & 14 \\
\hline $17 a$ & $\begin{array}{l}\text { Non-instructional staff at our institution do } \\
\text { understand how working with adult learners may } \\
\text { differ from working with younger, traditional } \\
\text { students. }\end{array}$ & $0.0 \%$ & $7.1 \%$ & $21.4 \%$ & $50.0 \%$ & $21.4 \%$ & 3.86 & 14 \\
\hline $17 \mathrm{~b}$ & $\begin{array}{l}\text { Non-instructional staff at our institution should } \\
\text { understand how working with adult learners may } \\
\text { differ from working with younger, traditional } \\
\text { students. }\end{array}$ & $0.0 \%$ & $0.0 \%$ & $0.0 \%$ & $50.0 \%$ & $50.0 \%$ & 4.50 & $\begin{array}{r}14 \\
\text { (Table } \\
\text { Continues) }\end{array}$ \\
\hline
\end{tabular}




\begin{tabular}{|c|c|c|c|c|c|c|c|c|}
\hline & \multirow[t]{2}{*}{ Questionnaire items } & \multicolumn{5}{|c|}{ Responses (\% in each category) } & \multirow[b]{2}{*}{$M$} & \multirow[b]{2}{*}{$N$} \\
\hline & & 1 & 2 & 3 & 4 & 5 & & \\
\hline $18 a$ & $\begin{array}{l}\text { Our institution does know that adult students at our } \\
\text { institution do not always treat higher education as a } \\
\text { priority. }\end{array}$ & $0.0 \%$ & $7.1 \%$ & $35.7 \%$ & $50.0 \%$ & $7.1 \%$ & 3.57 & 14 \\
\hline $18 \mathrm{~b}$ & $\begin{array}{l}\text { Our institution should know that adult students at } \\
\text { our institution do not always treat higher education } \\
\text { as a priority. }\end{array}$ & $7.1 \%$ & $0.0 \%$ & $14.3 \%$ & $57.1 \%$ & $21.4 \%$ & 3.86 & 14 \\
\hline
\end{tabular}


Table 7 offers a more detailed look at the responses from the transfer coordinators at four-year institutions, rank ordering the questionnaire items in terms of the gap between what is and what should be. This answers the third research question for the four-year respondents' sector, pointing to potential gaps between what is being done at the four-year institutions to help adult transfer students, and what should be done. Those items that yielded a gap of "1" or more will be highlighted, because these reflect areas that, in the opinion of respondents, the institutions need to improve.

Articulation and credit transfer. There were no statements within the articulation and credit transfer dimension in which four-year institution transfer coordinators had concerns.

Curriculum and instruction. First, as can be seen in the table, with a mean difference of 1.2, four-year college respondents were most concerned that their institutions may not offer courses at times and places that are convenient for students with extensive job and family obligations. This finding is not surprising, since four-year institutions have historically offered courses during daytime working hours that cater to residential students who are in the traditional college-going age range category. These are often the same hours that adult students are working at their jobs.

A second concern in the curriculum and instruction dimension (with a mean difference of 1.19) perceived by four-year respondents is that their institutions may not be providing bachelor's degree completion programs for place-bound community college graduates, either through online study or by bringing upper-division courses to the community colleges. This is not a surprising finding, since the number of bachelor's degree programs suited for adult students and offered in alternative locations or formats is limited. 
Institutional goals and policy. A concern noted within this dimension with a mean difference of 1.06, is that four-year respondents may feel that their institution could work more with other institutions across the state to support adult students. This finding was interesting because it was also a concern for the community college transfer coordinator respondents.

Another concern noted within this dimension and with a mean difference of 1 , is that four-year respondents may need to revisit academic policies to adjust them to support adult students. This finding is not surprising, since many adult students have college credits from past college experiences.

Student services and advising. Within the student services and advising dimension, and with a mean difference of 1.15 , four-year respondents were concerned that adult students transferring to their institutions from community colleges may not feel as welcome as younger students transferring from community colleges. This finding also seems to be a concern for the community college transfer coordinator respondents. This finding is not surprising, since adult transfer students may often feel left out.

An additional concern for four-year respondents, with a mean difference of 1.08 , was that orientation programs for new transfer students may not be as helpful for adult students as they are for traditional students. Orientation programs for adult students also seem to be a concern for the community college transfer coordinator respondents.

Still another concern from four-year respondents, with a mean difference of 1.07 , is that advising and other support services may not be designed for transfer students and offered at convenient times for adult students. This is not a surprising finding, given that four-year 
institutions sometimes offer advising and other support services for traditional students during daytime hours, which supports traditional student schedules. 
Table 7

Four-Year Institution Questionnaire Items Rank Ordered by The Difference Between What Is and Should Be Done for Adult Transfer Students

\begin{tabular}{|c|c|c|c|c|c|}
\hline Topical areas most relevant to the statements & $\begin{array}{c}\text { Mean } \\
\text { difference } \\
\text { between } \\
\text { what is } \\
\text { and what } \\
\text { should be }\end{array}$ & $\begin{array}{l}\text { Articulation } \\
\text { and credit } \\
\text { transfer }\end{array}$ & $\begin{array}{l}\text { Curriculum } \\
\quad \text { and } \\
\text { instruction }\end{array}$ & $\begin{array}{l}\text { Institutional } \\
\text { goals and } \\
\text { policy }\end{array}$ & $\begin{array}{l}\text { Student services } \\
\text { and advising }\end{array}$ \\
\hline $\begin{array}{l}\text { Our institution does/should offer courses at } \\
\text { convenient times and places that accommodate } \\
\text { students with extensive job and family obligations. }\end{array}$ & 1.2 & & $\mathrm{x}$ & & \\
\hline $\begin{array}{l}\text { Our institution does/should provide bachelor's } \\
\text { degree completion programs for place-bound } \\
\text { community college graduates, either through online } \\
\text { study or by bringing upper-division courses to the } \\
\text { community colleges. }\end{array}$ & 1.19 & & $x$ & & \\
\hline $\begin{array}{l}\text { Orientation programs for new transfer students } \\
\text { are/should be as helpful to adult students in making } \\
\text { them feel welcome and part of the institutional } \\
\text { culture as they are for younger, traditional students. }\end{array}$ & 1.08 & & & & (Table Con \\
\hline
\end{tabular}




\begin{tabular}{|c|c|c|c|c|c|}
\hline Topical areas most relevant to the statements & $\begin{array}{c}\text { Mean } \\
\text { difference } \\
\text { between } \\
\text { what is } \\
\text { and what } \\
\text { should be }\end{array}$ & $\begin{array}{c}\text { Articulation } \\
\text { and credit } \\
\text { transfer }\end{array}$ & $\begin{array}{l}\text { Curriculum } \\
\text { and } \\
\text { instruction }\end{array}$ & $\begin{array}{l}\text { Institutional } \\
\text { goals and } \\
\text { policy }\end{array}$ & $\begin{array}{c}\text { Student services } \\
\text { and advising }\end{array}$ \\
\hline
\end{tabular}

Advising and other support services are/should be designed to help students transferring from community colleges and are offered at times (or in online formats) that are convenient for adult working students.

Our institution does work/should work with other colleges and universities across the state to improve services for adult students.

Our institution revisits/should revisit academic policies and adjust them to support adult students.

Articulation agreements are/should be in place to

help graduates of vocational programs (i.e.,

Associate of Applied Science graduates) transfer to our institution.

Our institution does/should provide support services geared specifically for adult student transferring from community colleges.

Non-instructional staff at our institution do/should understand how working with adult learners may 


\begin{tabular}{|c|c|c|c|c|c|}
\hline Topical areas most relevant to the statements & $\begin{array}{l}\text { Mean } \\
\text { difference } \\
\text { between } \\
\text { what is } \\
\text { and what } \\
\text { should be }\end{array}$ & $\begin{array}{l}\text { Articulation } \\
\text { and credit } \\
\text { transfer }\end{array}$ & $\begin{array}{l}\text { Curriculum } \\
\text { and } \\
\text { instruction }\end{array}$ & $\begin{array}{l}\text { Institutional } \\
\text { goals and } \\
\text { policy }\end{array}$ & $\begin{array}{l}\text { Student services } \\
\text { and advising }\end{array}$ \\
\hline \multicolumn{6}{|l|}{$\begin{array}{l}\text { differ from working with younger, traditional } \\
\text { students. }\end{array}$} \\
\hline $\begin{array}{l}\text { Our institution does/should have a general studies } \\
\text { or an interdisciplinary bachelor's degree program } \\
\text { designed specifically for adult students. }\end{array}$ & 0.6 & & $x$ & & \\
\hline $\begin{array}{l}\text { Recruiting adult students is/should be a high priority } \\
\text { at our institution. }\end{array}$ & 0.6 & & & $x$ & \\
\hline $\begin{array}{l}\text { Our institution does/should reach out specifically to } \\
\text { adult students at community colleges, informing } \\
\text { them of their opportunities to transfer. }\end{array}$ & 0.6 & & & $x$ & \\
\hline $\begin{array}{l}\text { Articulation agreements are/should be as helpful to } \\
\text { adult students who come to the community college } \\
\text { with a variety of credits previously earned at other } \\
\text { institutions, as they are for younger students who } \\
\text { enroll at the community college immediately after } \\
\text { high school. }\end{array}$ & 0.59 & $x$ & & & \\
\hline $\begin{array}{l}\text { Adult students transferring to our institution } \\
\text { do/should have opportunities to become involved in } \\
\text { campus life. }\end{array}$ & 0.58 & & & & $\begin{array}{c}\mathrm{x} \\
\text { (Table Continues) }\end{array}$ \\
\hline
\end{tabular}




\begin{tabular}{|c|c|c|c|c|c|}
\hline Topical areas most relevant to the statements & $\begin{array}{c}\text { Mean } \\
\text { difference } \\
\text { between } \\
\text { what is } \\
\text { and what } \\
\text { should be }\end{array}$ & $\begin{array}{l}\text { Articulation } \\
\text { and credit } \\
\text { transfer }\end{array}$ & $\begin{array}{l}\text { Curriculum } \\
\text { and } \\
\text { instruction }\end{array}$ & $\begin{array}{l}\text { Institutional } \\
\text { goals and } \\
\text { policy }\end{array}$ & $\begin{array}{c}\text { Student services } \\
\text { and advising }\end{array}$ \\
\hline $\begin{array}{l}\text { Community college students who have earned } \\
\text { credits for learning in the military, on the job, or in } \\
\text { other non-collegiate settings do/should find it easy } \\
\text { to transfer those credits to your institution. }\end{array}$ & 0.54 & $x$ & & & \\
\hline $\begin{array}{l}\text { Faculty at our institution do/should understand how } \\
\text { teaching adult learners may differ from teaching } \\
\text { younger, traditional students. }\end{array}$ & 0.48 & & $x$ & & \\
\hline $\begin{array}{l}\text { Our institution does/should know that adult } \\
\text { students at our institution do not always treat higher } \\
\text { education as a priority. }\end{array}$ & 0.29 & & & & $x$ \\
\hline
\end{tabular}


The survey results for community colleges and four-year institutions have been

presented. The next section presents the results of the transfer coordinators group

conversations which were held with transfer coordinators to elicit perceptions of what the survey findings suggest about implications for practice.

\section{Final Transfer Coordinator Conversations}

As noted in Chapter Three, the eight transfer coordinators who participated in the first stage of the study were consulted after the survey data were collected. Each was asked the following questions via teleconference:

- What do the survey findings suggest about practice (that is, conclusions for services and programs needed to accommodate adult students as they make the transition from community colleges to four-year institutions)?

- What is some specific, actionable advice that you can recommend for these findings?

- Have the survey findings missed anything that might need to be examined in future research?

The rationale for asking transfer coordinators about the findings was to understand how the study findings might assist in the actual practice of helping adult students to transfer successfully. In addition, understanding if the survey findings missed anything that might need to be examined for future research was also important to learn from the transfer coordinators.

\section{What Survey Findings Suggest about Practice}

In terms of suggestions for practice, the participants suggested the importance of helping faculty and staff to understand that adult students are different from traditional students. Discussion ensued about how to educate faculty and staff members who may often 
constitute the only support systems for adult students who are working, managing school and taking care of children and aging parents. This concern was also found in the community college survey findings, where respondents felt that faculty may not understand how teaching adult students differs from teaching traditional students.

Another discussion item that was mentioned during the final conversations was how institutions offer organizations for student participation, but most of these organizations are not for adult students. This can leave adult students not feeling as welcome as traditional aged students. This idea of adult students not feeling as welcome as traditional aged students was also a concern in both the community college survey and the four-year institution survey.

\section{Specific, Actionable Advice}

As for specific, actionable advice that was recommended, respondents discussed the idea that many of their advising offices are holding later office hours for adult students who cannot access the services during regular workday hours. This service may help address the need for services that are geared specifically for adult students.

\section{Conclusion}

For this study, a mixed method approach was used. The qualitative components were the conversations with transfer coordinators. The quantitative component was the data collected from the surveys which were completed by transfer coordinators. The analysis of the data produced possible perceived concerns (the largest gaps that answer research question three), from the transfer coordinators. These findings are organized below under their respective themes. 


\section{Curriculum and Instruction}

- institutions may want to provide resources and support for faculty to help them understand how teaching adult students differs from teaching traditional students

- institutions may want to focus on providing bachelor's degree completion programs for place-bound community college graduates by offering either online study or bringing upper division courses to community colleges

Institutional Goals and Policy

- institutions may want to work with other institutions around the state to improve services for adult students

- institutions may want to revisit recruiting adult students to make sure it is a priority

- institutions may want to revisit academic policies and adjust them to support adult students

\section{Student Services and Advising}

- $\quad$ adult students may not feel as welcome as traditional students

- institutions may want to think about providing support services, including orientation programs, that are offered in convenient formats for adult students

This chapter shared the perceived findings of the transfer coordinators of the research study. Chapter five will provide a discussion on why these findings are important, and share recommendations on services that colleges and universities might want to consider in working with adult students who are transferring from community colleges to four-year institutions. The chapter also provides recommendations for future study on this topic. 


\section{CHAPTER V: DISCUSSION AND CONCLUSIONS}

The purpose of this study was to add to the small body of research on services that are offered to help adult students transfer successfully from the community college to the university. Data for this mixed method exploratory study was gathered through a survey of transfer coordinators at Illinois institutions of higher education, including community colleges, public four-year institutions, and private four-year institutions. In addition to the surveys, telephone conversations with transfer coordinators were also held to gather insights from these professionals who often work with adult students. A total of 35 transfer coordinators from Illinois community colleges, public four-year institutions and private four-year institutions completed the surveys.

There were two surveys - one for community college transfer coordinators and one for public four-year institution and private four-year institution transfer coordinators. Each survey consisted of two sections. The first section asked respondents for contextual information about their higher education institutions, including total enrollment and percentage of the institution's student enrollment comprised of students who are 25 years of age or older. The second section of each survey asked respondents to rate their agreement to paired statements regarding institutional services for adult transfer students. These paired statements were identified in the literature as being requisites for institutional service and were organized around the themes of articulation and credit transfer questions, curriculum and instruction questions, institutional goals and policy, and student services and advising. The statements were also gleaned from conversations with transfer coordinators. This study did not seek to evaluate the success of transfer services for adult students. Rather, it sought to examine 
transfer coordinator perceptions of what services tend to be provided, what services should be provided, and how actual practice may differ from desired practice. The study sought to understand the following research questions:

1. What do transfer coordinators perceive that their colleges should be doing to help adult students transfer from community colleges to universities?

2. What do transfer coordinators perceive their colleges are actually doing to help adult students transfer?

3. Is there a gap between what coordinators perceive that their colleges should be doing to help adult students transfer from community colleges to universities and what they perceive that their colleges are actually doing?

This chapter offers an interpretative analysis of the results as well as recommendations for further study.

The data collected in part one of the questionnaire for both community colleges and four-year institutions provided a sense of what enrollments were, the magnitude of transfer students who transferred from a community college to a four-year institution, and what percentage of the institution's student enrollment is 25 years of age or older. The picture that emerges suggests that for all institutions, 21 to 40 percent of their student enrollment is 25 years of age and older. The National Center for Education Statistics (2015) reports that there were 5,975,126 adult students enrolled in undergraduate postsecondary education. This may suggest that a healthy number of institutional enrollments are adult students. This may also suggest that the need for higher education institutions to offer services for adult students is important. 


\section{The Thesis of the Study}

The thesis of this study is that although strides have been made to help adult students succeed in transferring, adult students may still be marginalized. This finding is supported by

the literature. Sissel, Hansman and Kasworm (2002) argue that "services, programs, and policies for adults typically occur as peripheral add-ons, operating as exceptions to the mainstream programs for traditional students" (p. 21). In addition, Bowl (2001), argues that survival at the university for adult students is difficult, because many higher education institutions exhibit little interest in their life circumstances, such as "financial responsibility, childcare, family, and community expectations that are central to their lives" and that must be attended to in addition to managing their college studies (p. 157). Perhaps most poignant, Scobey (2016) posits that although adult students are included - "they are included in ways that set them aside and set them up for failure" (para. 12). This marginalization may make it difficult for adult students to be successful in their educational endeavors.

\section{Discussion - Points of Commonality and Divergence}

In examining the community college survey results, the four-year institution survey results, and the feedback from the final focus group discussion, there are points of commonality as well as divergence. The survey questions were organized within four themes: articulation and credit transfer, curriculum and instruction, institutional goals and policy and student services and advising. The discussion of the points of commonality and divergence will be organized within these themes. 


\section{Articulation and Credit Transfer}

Interestingly, the first theme - articulation and credit transfer, may not have been worrisome for respondents from community colleges or four-year institutions, since no items in this theme had a difference of 1.0 or greater between "does reflect" and "should reflect" categories. In addition, problems with articulation agreements did not emerge in the telephone conversations with transfer coordinators. Conceivably, the articulation agreements currently in place may be working to help adult transfer students understand what courses will transfer to a four-year institution. It is also possible that students don't find it complicated to transfer credit earned from on-the-job experiences, the military, or other non-collegiate settings. It may also be possible that despite a few shortfalls within this theme, shortfalls in other areas may have a critical impact. Thus, in terms of articulation and the transfer of credit, policies in place may further the CAEL principles for effective work with adult students, specifically the principle of providing transitions or pathways that lead from college programs

to educational and career goals - may be appropriate and may be working well for these higher education institutions.

\section{Curriculum and Instruction}

Community college survey respondents and phone conversation participants were concerned that faculty at their institutions may not understand how teaching adult learners could differ from teaching younger, traditional students. As noted in Chapter Two, the traditional subject-centered pedagogy employed with younger learners may be inappropriate for adults who bring a "task or problem-centered orientation to learning" that derives from something they have experienced or a "need in their life" (Ross-Gordon, 2003, p. 44). In 
addition, four-year college respondents were concerned that their institutions may not offer courses at convenient times and places that accommodate students with extensive job and family obligations. Four-year respondents were also concerned that their institutions may not be providing bachelor's degree completion programs for place-bound community college graduates.

Perhaps the concerns expressed about faculty capacity to teach adult students reflect the fact that community colleges are now serving greater proportions of traditional students than adult students, since traditional students now comprise $60 \%$ of the overall student body (Orbesen, 2013). The student body of the community colleges has become younger overall, resulting in greater emphasis on work with traditional students (Mullin, 2012). This might be why some faculty members at community colleges may not have extensive experience teaching adult students. If so, more may need to be done to help institutions adhere to the CAEL principle emphasizing the need to help "faculty use multiple methods of instruction" (CAEL, 2018, para. 9) to teach adult learners. Such faculty development may eliminate a key institutional barrier, as Cross (1981) might put it, to student success. It may also foster the type of "connecting classroom" that according to Donaldson and Graham (1999) encompasses adult student engagement with their studies and the institution.

Survey responses expressing concern that four-year institutions may not always offer courses at convenient times and places or provide accessible bachelor's degree completion programs may reflect a shortfall in meeting the CAEL emphasis on "outreach to adult learners by overcoming barriers of time, place, and tradition in order to create lifelong access to educational opportunities" (CAEL, 2018, para. 5). If the four-year institutions were to offer 
courses in a variety of formats, perhaps adult students could choose which works best for them, and this would eliminate what Cross (1981) calls institutional barriers that are posed by courses and bachelor's degree programs that are only convenient for full-time or younger students who don't have job or family responsibilities.

\section{Institutional Goals and Policy}

Findings concerning the third theme - institutional goals and policy - revealed a concern among both community college respondents and four-year respondents that their institutions may not be working with other colleges and universities around the state to improve services for adult students. Lane (2015) states that in light of the limited funding available for degreecompletion efforts, working together with other institutions is an "essential strategy for leveraging existing resources and building program sustainability" (p. 1).

In addition, community college respondents were concerned that recruiting adult students to their institutions may not be a priority. Shugart (2008) noted that community colleges are "leading among the various sectors of higher education in offering a scalable response to mature students" (p. 19). Perhaps this finding reflects the idea that adult students often think about college for a long time before committing. In the author's experience, adult students take approximately 15 months to decide to apply and enroll in a college degree program. Burge (2015) states that adult students may be in the pipeline for a long time [before committing] to enrolling in college. It's possible that community colleges may be recruiting adult students, but there is a substantial amount of time between talking with them and actually enrolling them. It is also possible that community colleges may want to think about doing more to recruit adult students and to make this recruitment a priority. Brown (2004) 
posits that in order to market to adult students, higher education institutions need to know their students; they need to know their "needs, interests, motivating factors, barriers and communication styles in order to be most effective" (p. 53).

Conversely, four-year institution survey respondents were concerned that their institutions may need to revisit academic policies, adjusting them to support adult students. Focus group respondents did not mention any concerns that fall under this theme. All these shortfalls relate to the CAEL principle emphasizing institutional adaptation to the "changing expectations of external stakeholders" (CAEL 2018, para. 1). In this case, the external stakeholders may be the adult students who are thinking about enrolling in higher education. Institutions may want to keep these external stakeholders in mind as they work to recruit adult students, since these students may have specific academic needs that need to be met if they are to matriculate and be successful. When institutions do not keep these external stakeholders (adult students) in mind, they may seek out other institutions for their educational needs.

\section{Student Services and Advising}

Survey responses concerning the fourth and final theme - student services and advising -yielded many concerns. Community college respondents, four-year college respondents and telephone conversation participants were all concerned that adult students transferring may not feel as welcome as younger students transferring. Perhaps this reflects the tendency of campus activities to focus on out-of-class opportunities for involvement that don't appeal to adult students or help them stay engaged with the campus community (Donaldson \& Graham, 1999), as well as the concern that faculty members might not always understand effective 
approaches to teaching adult learners (as noted above). Again, efforts to engaging "connecting classrooms, as described by Donaldson and Graham (1999), may be key to the creating of a more welcoming campus environment.

In addition, both community college respondents and four-year respondents were concerned that orientation programs may not be as helpful for adult students as they are for traditional students. Orientations for students may likely have been created with the traditional student in mind. Edwards and Person (1997) posit that colleges will not fulfill the needs of adult students if they use existing programs designed (for traditional students) to orient adult students. If these orientations are to help adult students, they must be designed for adult students "to support their educational goals and transition to college" (Edwards \& Person, 1997, p. 19).

Both four-year respondents and telephone conversation respondents were concerned that advising and other support services may not be designed for transfer students and offered at convenient times for adult students. Finally, community college respondents were concerned that their institutions may not provide specific support services for adult students who plan to transfer. These possible shortfalls may all fall in line with the CAEL emphasis on providing "comprehensive academic and student support systems" for adult students (CAEL, 2018, para. 8). The absence of these support systems could constitute, in Cross's (1981) words, a significant institutional barrier. 


\section{Implications for Practice}

This study focused on transfer coordinator perceptions of what institutions are and should be doing to help adult transfer students. Possible implications from the findings are discussed below.

\section{Implication 1}

College and universities should provide resources and support for faculty to help them understand how teaching adult students differs from teaching traditional students. The faculty development office is a great resource at colleges and universities that could provide workshops and other related training to help faculty understand best practices in teaching adult students. It is possible that faculty don't always have experience in working with adult students. Sometimes, their experience with students is limited to working with traditional aged students. As noted earlier in this study, teaching traditional students is different than teaching adult students. Brinthaupt and Eady (2014) conducted a study of faculty members' attitudes, perceptions and behaviors toward adult students. Their results showed that although faculty had positive attitudes about their adult learners, this optimism did not translate into "frequent or substantial classroom activities that capitalized on the unique perspectives and characteristics of adult learners (p. 138)."

Part of this may stem from infrequent exposure to adult students or in some cases, a situation where faculty routinely have a small subset of adult students mixed in with traditional students. Faculty may not internalize or consistently realize that the learning needs of traditional students and adult students are quite different from one another (Thompson \& Sheckley, 1997). Because there are different types of learners, professors may need to further 
their "pedagogical knowledge or intelligence" in order to increase their teaching effectiveness in delivering their course materials (Kirpilani, 2017, p. 73). Faculty development programs built on adult education principles and that facilitate "reflection on practice" among college professors (Wlodarsky, 2018, p. 98) may be a promising approach to furthering this knowledge.

When thinking about the frameworks used for this study, the Donaldson Graham (1999) model of adult learning outcomes helps us to consider effective ways of teaching and engaging adult students. Perhaps faculty could use the adult cognition element in the model to understand that adult students bring prior experience to their college experience. Knowing that adult students will bring this with them to the classroom may help faculty to understand how they can incorporate this prior experience into their teaching repertoire. Perhaps they can incorporate this prior experience into the course assignments so that adult students can have ways to apply their prior knowledge to class coursework. This may also help alleviate dispositional barriers that Cross (1981) states are present when adult students feel that their self-perceptions as students may not be as strong as traditional students.

\section{Implications 2 and 3}

Colleges and universities should provide course offerings at convenient times and places as well as bachelor's degree completion programs for place-bound community college graduates.

In addition, institutions should work with other colleges and universities around the state to collaborate and improve services for adult students.

Implications two and three can be tied together. Forging interinstitutional partnerships would allow colleges and universities to share their physical spaces, allowing them to offer 
courses at convenient times and places and facilitating the development of bachelor's degree completion programs. In the author's experience, collaborations between community colleges and universities can be invaluable in offering adult student's alternative ways of taking college courses and earning bachelor's degrees. These collaborations may be the only way that adult students can earn their bachelor's degrees. Shugart and Harrison (2011) state that policies and practices need to be developed that encourage deeper and more strategic collaboration between community colleges and four-year institutions. Such policies and practice include creating individualized pathways that provide "a personal roadmap for students based on their life circumstances and personal goals" (Shugart \& Harrison, 2011, p. 44). They also advocate for written plans of study for both the associate's and the bachelor's degrees whereby support is garnered from both the community college and the four-year institutions to which students transfer. This written plan will ensure there is a pathway for students to follow, which will help to reduce inefficiency in credit accumulation and help students see the ultimate goal they are aiming for and the path that will lead them to that goal, thereby increasing their motivation (Shugart \& Harrison, 2011).

Partnerships with other institutions foster collaboration, which often leads to new ideas and ways to help both students and the institutions involved. Shugart and Harrison (2011) also share important points to remember when institutions form partnerships and work together. Those points include (a) remember to keep the focus on students, (b) don't let egos get in the way, (c) tackle the hard facts by disclosing data and analyzing it as a group, (d) agree on common principles that each partner institution wants to protect, (e) don't over think the 
project, (f) collaborate in an important area for both partner schools and (e) be selective develop a few key, meaningful partnerships instead of several shallow partnerships.

In addition to partnerships, the creation of a statewide advisory board might also foster the opportunity to join forces with colleagues and begin conversations about how colleges and four-year institutions could jointly create educational opportunities for adult students by pooling resources and working together on mutually beneficial programs. Statewide advisory boards could ask community leaders to participate, especially in the case of community colleges that rely on local funding from taxpayers (Nagai \& Nehls, 2014). Advisory boards are becoming common fixtures in universities, colleges and schools. They are often comprised of industry experts who offer "guidance, advisement and fundraising aptitude" and also act "as a sounding board" (Nagai \& Nehls, 2014, p. 4).

The creation of these collaborations could help alleviate institutional barriers, along the lines discussed by Cross (1981) that might discourage adult students from participating in educational opportunities. By working together, institutions might identify and correct rules and regulations that are not helpful to adult students. Institutions could also come together and adopt a standard set of rules and regulations that they can all use when working with adult students. The CAEL principles for effective work with adult students could be used as a guide, including principles concerning financing options to pay for college, the clarification of life and career goals before enrollment, the creation of partnerships to develop internships and job opportunities, the development of academic and student support systems, and the provision of transitions or pathways that lead from college degree programs to educational goals. 


\section{Implication 4}

Colleges and universities may want to consider ways to make adult students feel connected to the institution and as welcome as traditional students.

Survey respondents expressed a concern that adult students might not be as high a priority on campus as traditional students. Adult students feel connected and welcome when they feel that their institution cares about them. Caring about them means that they feel they are an important part of the campus. This also means that when adult students are important, rules and regulations are created or revised with adult students in mind. Adult students also feel welcome and connected when their concerns are validated by administrators.

The literature offers suggestions for combatting the possibility that adult students might feel unwelcomed and marginalized. Spellman (2007) suggests removing enrollment and retention barriers for adult students by offering developmental courses in reading, math and English and educating students about financial aid options.

In another example, Cannady, King and Blendinger (2012) discuss ways in which their university library helped adult students use library resources and gain the self-confidence needed to successfully complete research. The library developed services specifically for the adult learner, which included scheduling research appointments with the librarian at night and on the weekends, providing contact information on library faculty, library research guides that were subject and course specific, and offering library orientation sessions (Cannady, King \& Bledinger, 2012). This type of assistance helped assure that the library itself did not pose an institutional barrier to the success of adult students. 


\section{Implication 5}

Student Services and Advising. Institutions may want to consider providing support services offered at convenient times for adult students.

Study findings suggest the need to revisit services that might be needed to help adult transfer students. Transfer centers are an example. As Collins, Navarro, and Stinard (2011) note, "Transfer centers provide an efficient and flexible strategy to ensure services are in place that can support transfer students' successful transition, retention and graduation" (p. 56). Yet it can be helpful to determine the extent to which they accommodate adult learners as well as traditional-age students. For example, while the centers might be viewed as a physical space on campus where students can find transfer information, it may be useful to provide a "virtual" online transfer center for place-bound students or those who live at a distance from campus and aren't able to travel frequently.

In addition, colleges may need to provide vital "positive emotional support for returning adult students" (Flint \& Frey, 2003, p. 74).

Support services could therefore include mental health counselors who are attuned to the challenges and needs of adult students and who are available for counseling sessions when adult students may need extra support. Indeed, the complex lives that adult students lead can sometimes exacerbate stress and anxiety issues, and counseling can be helpful for adult students who struggle with these developmental and life issues (Benshoff, Cashwell, \& Rowell, 2015). Group counseling, offered in an online environment, may also be a way to share issues with other students who are in similar situations and need an outlet in order to share their struggles (Benshoff, Cashwell \& Rowell, 2015). 
Finally, academic advising could be offered and tailored specifically to the issues that adult students face. Perhaps orientation programs will be needed. The literature posits that many adult learners have questions about prior college credit, often earned from multiple higher education institutions (Steele \& Erisman, 2016). Academic advising could be offered via online platforms or during hours that are convenient for working, adult students. Rice (2003) cites an example of one institution, at which adult students can meet with student services staff until $8 \mathrm{pm}$ on Wednesday evenings and also on Saturdays by appointment. Another university offers adult student services from 8 am to $7 \mathrm{pm}$ Monday through Friday throughout the entire academic year (Rice, 2003). Compton, Cox and Laanan (2006) report that Empire College in New York provides online math and writing resources all hours of the day. These scheduling options are convenient for adult students who juggle many roles and responsibilities.

\section{Future Research}

This dissertation included several different paired statements comparing perceptions of what is happening versus what should be happening for adult students seeking to transfer successfully from community colleges to four-year institutions. As mentioned previously, there were six "does reflect" statements that respondents from four-year institutions felt they may not be doing at their institutions (see page 81). These statements include:

- Community college students who have earned credits for learning in the military, on the job, or in other non-collegiate settings do find it easy to transfer those credits to your institution.

- Articulation agreements are in place to help graduates of vocational programs (i.e., Associate of Applied Science graduates) transfer to our institution. 
- Our institution does provide bachelor's degree completion programs for place-bound community college graduates, either through online study or by bringing upper-division courses to the community colleges.

- Our college does offer courses at convenient times and places that accommodate students with extensive job and family obligations.

- Our institution revisits academic policies and adjusts them to support adult students.

- Our institution does work with other colleges and universities across the state to improve services for adult students.

Future qualitative analyses of the perceptions and experiences of adult students who have transferred to universities may shed light on the extent (if at all) to which the universities fall short in terms of the services delineated in these statements and the impact on the students' transfer experiences.

Another possibility for future research lies in the potential of surveying or interviewing current adult students themselves (both those who have already transferred and those community college students who are preparing to transfer) in order to understand their perspectives on what transfer services will help them make a successful transition from a community college to a four-year institution. The transfer coordinators in the pilot group suggested this idea. Talking with actual adult students about this topic may yield some interesting ideas and ways to help them in their educational endeavors.

Another possible study could involve qualitative or ethnographic research focusing on

- adult students who had started their undergraduate education at some point in the past, stopped out because of work or family circumstances, and restarted the process of 
obtaining a college degree; adult students who have been in the military and did not start their college experience until after successful stints as enlisted personnel

- adult students who entered community college as a result of losing their employment (as described, for example, by Dewar \& Epstein (2007) and whose educational goals include eventual transfer.

Further study could also be completed to gain a better understanding of the effectiveness of the current advising and support services at higher education institutions and how they might be revised to be more convenient and helpful for adult students. Perhaps this could be completed by evaluating the services at individual institutions to understand if there are possible best practices that could be gleaned from the research on how best to offer effective services.

Finally, the transfer coordinators participating in the telephone interviews noted that it would be useful to replicate this study in the future. The intent would be to determine if perceptions of needed services change over time as the nature and scope of higher education changes. 


\section{REFERENCES}

Allen, T. O., \& Zhang, Y. (2016). Dedicated to their degrees: Adult transfer students in engineering baccalaureate programs. Community College Review, 44(1), 70-86.

American Council on Education. (2018). Adult learners guide to PLA. Retrieved from https://www.acenet.edu/news-room/Pages/Adult-Learners-Guide-to-PLA.aspx

Anderson, R. (2013). Adult learners and student engagement: A study of the influence of student engagement on community college students and their intention to transfer (Unpublished doctoral dissertation). lowa State University, Ames. Retrieved from https://lib.dr.iastate.edu/cgi/viewcontent.cgi?article=4513\&context=etd

Bailey, T. R., Jaggers, S. S., \& Jenkins, D. (2015). Redesigning America's community colleges: A clearer path to student success. Cambridge, MA: Harvard University Press.

Barnett, B. G., \& Caffarella, R. S. (October, 1992). The use of cohorts: A powerful way for addressing issues of diversity in preparation programs. Paper presented at the Annual Meeting of University Council for Educational Administration, Minneapolis, MN.

Benshoff, J. M, Cashwell, C. S., \& Rowell, P. C. (2015). Graduate students on campus: Needs and implications for college counselors. Journal of College Counseling, 18, 82-94.

Berman, E. A. (2017). An exploratory sequential mixed methods approach to understanding researchers' data management practices at UVM: Integrated findings to develop research data services. Journal of eScience Librarianship, 6(1), 1-24.

Bers, T. (2013). Deciphering articulation and state/system policies and agreements. New Directions for Higher Education, 162, 17-26. doi: 10.1002/he.20053 
Bers, T., \& Younger, D. (2011). The role of feeder community colleges. In M. A. Poisel \& S. Joseph (Eds.), Transfer students in higher education: Building foundations for policies, programs, and services that foster student success (Monograph No. 54, pp. 29-42). Columbia, SC: University of South Carolina, National Resource Center for the First-Year Experience and Students in Transition. doi: 10.1177/0741713606294235

Blumenstyk, G. (2018, February 12). Bringing back adult students takes more than a catchy campaign. Chronicle of Higher Education, Retrieved from https://www.chronicle.com/article/Bringing-Back-Adult-Students/242526

Bowl, M. (2001). Experiencing the barriers: Non-traditional students entering higher education. Research Papers in Education, 16(2), 141-160.

Bragg, D. D., \& Soler, M. C. (2017). Policy narratives on applied baccalaureate degrees: implications for student access to and progression through college in the United States. Journal of Vocational Education and Training, 69(1), 123-146 doi: http://dx.doi.org/10.1080/13636820.2017.1289550

Brinthaupt, T. M., \& Eady, E. (2014). Faculty members' attitudes, perceptions, and behaviors toward their nontraditional students. The Journal of Continuing Higher Education, 62, 131-140. doi: 10.1080/07377363.2014.956027

Brookfield, S. D. (1993). Self-directed learning, political clarity, and the critical practice of adult education. Adult Education Quarterly, 43, 227-242. doi: 10.1177/0741713693043004002 Brown, J. A. (2004). Marketing and retention strategies for adult degree programs. New Directions for Adult \& Continuing Education, 103, 51-60. 
Burge, R. (2015). Why aren't colleges doing a better job of recruiting adult students? Retrieved from Stamats website: https://www.stamats.com/stamats-insights/energize-yourmarketing/2015/why-arent-colleges-doing-a-better-job-of-recruiting-nontraditionalstudents

Cannady, R. E., King, S. B., \& Blendinger, J. G. (2012). Proactive outreach to adult students: A department and library collaborative effort. The Reference Librarian, 53, 156-169.

Cardozier, V. R. (1993). University of Texas Permian Basin. New Directions for Higher Education, 82, 89-104.

Cleary, M. N. (2013). Flowing and freestyling: Learning from adult students about process knowledge transfer. College Composition and Communication, 64, 661-687.

Cohen, A. M., \& Brawer, F. B. (1987). The collegiate function of community colleges: Fostering higher learning through curriculum and student transfer. San Francisco, CA: Jossey-Bass.

Cohen, A.M., Brawer, F.B. \& Kisker, C.B. (2014). The American community college (6 ${ }^{\text {th }}$ ed.). San Francisco, CA: Jossey-Bass.

Collins, J., Navarro, C. P., \& Stinard, C. (2011). Transfer student centers. In M. A. Poisel \& S. Joseph (Eds.), Transfer students in higher education: Building foundations for policies, programs, and services that foster student success (Monograph No. 54, pp. 55-69). Columbia, SC: University of South Carolina, National Resource Center for the First-Year Experience and Students in Transition.

Community College of Philadelphia Dual Admission Agreement. (2018). Retrieved from https://www.ccp.edu/academic-offerings/transfer-opportunities/dual-admissionstransfer-partnerships 
Compton, J. L., Cox, E., \& Laanan, F.S. (2006). Adult learners in transition. New Directions for Student Services, 114, 73-80.

Compton, P. K., Tafel, J., Law, J., \& Gustafson, R. (2001). Faculty-determined course equivalency: The key to Ohio's transfer mobility system. In Kisker, C.B., \& Wagoner, R.L. (Eds), Implementing transfer associate degrees: Perspectives from the states (pp. 4554). San Francisco, CA: Jossey-Bass.

Cope, K.L. (2012). Widening and wandering the short road to success: The Louisiana transfer degree guarantee. In Kisker, C.B., \& Wagoner, R.L. (Eds.), Implementing transfer associate degrees: Perspectives from the states (New Directions for Community Colleges, No. 160, pp. 31-44). San Francisco, CA: Jossey-Bass.

Council on Adult and Experiential Education (CAEL). (2008). Adult learning in focus: National and state-by-state data. Retrieved from https://files.eric.ed.gov/fulltext/ED509934.pdf

Council on Adult and Experiential Education (CAEL). (2018). Ten principles for effectively serving adult learners. Retrieved from https://www.cael.org/higher-education-ten-principles

Cross, K. P. (1981). Adults as learners: Increasing participation and facilitating learning. San Francisco, CA: Jossey-Bass.

Dewar, M., \& Epstein, D. (2007). Planning for "Megaregions" in the United States. Journal of Planning Literature, 22(2), 108-124. doi: 10.1177/0885412207306615\

Donaldson, J. F., \& Graham, S. (1999). A model of college outcomes for adults. Adult Education Quarterly, 50, 24-40.

Dougherty, C. B. (2009). Measuring effectiveness in transfer practices for adult learners. The Journal of Continuing Higher Education, 57, 54-58. doi: 10.1080/07377360902839933 
Education Commission of the States. (2018). 27 is the new 18: Adult students on the rise.

Retrieved from https://www.ecs.org/27-is-the-new-18-adult-students-on-the-rise/

Edwards, R., \& Person, D. R. (1997). Retaining the adult student: The role of admission counselors. Journal of College Admission, 154, 18-21.

Ellis, M.M. (2013). Successful community college transfer students speak out. Community college journal of research and practice, 37(2), 73-84. doi: 10.1080/10668920903304914

Emory, D., Raymond, L., Lee, K., \& Twohy, S. (2016). The Academic I-BEST: A model for precollege student success in college transfer programs. Journal of Research and Practice for Adult Literacy, Secondary, and Basic Education, (5)3, 43-49.

Erisman, W., \& Steele, P. (2015). Adult college completion in the 21st Century: What we know and what we don't know. Retrieved from Higher Ed Insight website: https://higheredinsight.files.wordpress.com/2015/06/adult_college_completion_20151. pdf

Fairchild, E. E. (2003). Multiple roles of adult learners. In Kilgore, D., \& Rice, P.J. (Eds.), Meeting the special needs of adult students (pp. 11-16). San Francisco, CA: Jossey-Bass.

Fann, A. (2013). Campus administrator and student perspectives for improving transfer policy and practice. New Directions for Higher Education, 162, 27-37. doi: 10.1002/he.20054

Flint, T.A., \& Frey, R. (2003). Alternative programming for adults. In Kilgore, D., \& Rice, P.J. (Eds.), Meeting the special needs of adult students (pp. 69-79). San Francisco, CA: Jossey-Bass.

Fox, R.C., \& Harvey, L.S. (1994). Metropolitan State University. New Directions for Higher Education, 82, 77-87. 
Frost, S.H. (1991). Academic advising for student success: A system of shared responsibility. (ASHE-ERIC Higher Education Report No. 3). Retrieved from https://eric.ed.gov/contentdelivery/servlet/ERICServlet?accno=ED339272

Furbeck, L. F. (2011). Enrollment management of transfer students. In M. A. Poisel \& S. Joseph (Eds.), Transfer students in higher education: Building foundations for policies, programs, and services that foster student success (Monograph No. 54, pp. 13-28). Columbia, SC: University of South Carolina, National Resource Center for the First-Year Experience and Students in Transition.

Ginsburg, M.B., \& Wlodkowski, R.J. (2010). Access and participation. In C. E. Kasworm, A. D. Rose, \& J. M. Ross-Gordon (Eds.), Handbook of adult and continuing education (pp. 2532). Thousand Oaks, CA: SAGE Publications, Inc.

Graham, S., \& Donaldson, J. F. (1999). Adult students' academic and intellectual development in college. Adult Education Quarterly, 49, 147-161. doi: 10.1177/074171369904900302

Hansman, C. A., \& Mott, V. W. (2010). Adult learners. In C. E. Kasworm, A. D. Rose, \& J. M. Ross-Gordon (Eds.), Handbook of adult and continuing education (pp. 13-23). Thousand Oaks, CA: SAGE Publications, Inc.

Herrera, A., \& Jain, D. (2013). Building a transfer-receptive culture at four-year institutions. New Directions for Higher Education, 162, 51-59. doi: 10.1002/he.20056

Illinois Articulation Initiative. (2019). Transfer coordinator responsibilities. Retrieved from https://itransfer.org/transfercoordinators/tcresponsibilities.php 
Illinois Community College Board. (2016). Student enrollments and completions in the Illinois community college system. Retrieved from https://www.iccb.org/iccb/wp-content/pdfs/reports/Annual_Enroll_Comp_2015.pdf

Illinois State University. (2018). An articulation agreement between Danville Area Community College and Illinois State University. Retrieved from http://registrar.illinoisstate.edu/downloads/articulation_agreements/DanvilleAreaCC.p $\mathrm{df}$

iTransfer. (2018). IAl general education package requirements. Retrieved from http://itransfer.org/courses/gecc/geccpackage.php

Jacobs, F., \& Hundley, S. (2010). Understanding and supporting adult learners: A guide for colleges and universities. San Francisco, CA: Jossey-Bass.

Kasworm, C. E. (2003). Setting the stage: Adults in higher education. In D. Kilgore, \& P. J. Rice (Eds.), Meeting the special needs of adult students (pp. 3-10). San Francisco, CA: JosseyBass.

Kasworm, C.E. (2008). Emotional challenges of adult learners in higher education. New Directions for Adult and Continuing Education, 120, 27-34. doi: 10.002/ace313s

Kasworm, C.E. (2014). Paradoxical understandings regarding adult undergraduate persistence. The Journal of Continuing Higher Education, 62, 67-77. doi: $10.1080 / 07377363.2014 .916587$

Kember, D. (1999). Integrating part-time study with family, work and social obligations. Studies in Higher Education, 24(1), 109-124. 
Kirpilani, N. (2017). Developing self-reflective practices to improve teaching effectiveness. Journal of Higher Education Theory \& Practice, 17(8), 73-80.

Knowles, M. S. (1980). The modern practice of adult education: From pedagogy to andragogy. Englewood Cliffs, NJ: Prentice Hall Regents.

Laanan, F. S. (2001). Transfer student adjustment. In F. S. Laanan (Ed.), Transfer students: Trends and issues (pp. 5-13). San Francisco, CA: Jossey Bass.

Laanan, F. S. (2007). Studying transfer students: Part II: Dimensions of transfer student adjustment. Community College Journal of Research and Practice, 31(1), 37-59. doi: $10.1080 / 10668920600859947$

Lane, P. (2015, April). Collaboration and coordination to improve adult college completion efforts. Policy Exchanges. Retrieved from https://files.eric.ed.gov/fulltext/ED557761.pdf

Lester, J., Leonard, J. B., \& Mathias, D. (2013). Transfer student engagement: Blurring of social and academic engagement. Community College Review, 41, 202-222.

Lumina Foundation (2018). Lumina Foundation, our work. Retrieved from https://www.luminafoundation.org/lumina-goal\#goal-urgent

Macdonald, K. (2018). A review of the literature: The needs of nontraditional students in postsecondary education. Retrieved from American Association of Collegiate Registrars and Admissions Officers website: http://www.aacrao.org/resources/resources-detailview/semq-5-4-a-review-of-the-literature--the-needs-of-nontraditional-students-inpostsecondary-education

Marling, J. L. (2013). Navigating the new normal: Transfer trends, issues and recommendations. New Directions for Higher Education, 162, 77-87. doi: 10.1002/he.20059 
Merriam, S.B., Caffarella, R. S., \& Baumgartner, L. M. (2007). Learning in adulthood: $A$ comprehensive guide. San Francisco, CA: John Wiley \& Sons, Inc.

Miller, A. (2013). Institutional practices that facilitate bachelor's degree completion for transfer students. New Directions for Higher Education, 162, 39-50. doi: 10.1002/he.20055

Mullin, C. M. (2012, February). Why access matters: The community college student body (Policy Brief 2012-01PBL). Washington, DC: American Association of Community Colleges.

Nagai, J., \& Nehls, K. (2014). Non-alumni advisory board volunteers. Innovative Higher Education, 39(1), 3-16.

National Center for Education Statistics. (2015). Table 303.50 Total fall enrollment in degreegranting postsecondary institutions, by level of enrollment, control and level of institution, attendance status, and age of student: 2011. Retrieved from https://nces.ed.gov/programs/digest/d13/tables/dt13_303.50.asp

National Center for Education Statistics. (2016). Table 303.50 Total fall enrollment in degreegranting postsecondary institutions, by level of enrollment, control and level of institution, attendance status, and age of student: 2015. Retrieved from https://nces.ed.gov/programs/digest/d16/tables/dt16_303.50.asp

National Center for Education Statistics. (2018). Definitions and data. Retrieved from https://nces.ed.gov/pubs/web/97578e.asp

Obama Whitehouse Archives. (2018). Education knowledge and skills for the jobs of the future. Retrieved from https://obamawhitehouse.archives.gov/issues/education/higher-education 
O'Meara, R., \& Hall, T., \& Carmichael, M. (2007). A discussion of past, present, and future articulation models at postsecondary institutions. Journal of Technology Studies, 33(1), 9-16.

Orbesen, J. (2013). Students at community colleges are getting younger and younger. The Atlantic. Retrieved from https://www.theatlantic.com/education/archive/2013/09/students-at-communitycolleges-are-getting-younger-and-younger/280030/

Osam, E. K., Bergman, M., \& Cumberland, D. M. (2017). An integrative literature review on the barriers impacting adult learners' return to college. Adult Learning, 28(2), 54-60.

Patton, J., \& Pilati, M. (2012). Faculty reflections on implementing associate degrees for transfer in California. In C. B. Kisker, \& R. L. Wagoner (Eds.), Implementing transfer associate degrees: Perspectives from the states (pp. 55-68). San Francisco, CA: Jossey-Bass.

Pegg, A., \& Di Paolo, T. (2013). Narrating unfinished business: Adult learners using credit transfer to re-engage with higher education. Studies in Continuing Education, 35(2), 209-223.

doi: http://dx.doi.org/10.1080/0158037X.2012.736382

Poisel, M. A., \& Joseph, S. (2011). Transfer students in higher education: Building foundations for policies, programs, and services that foster student success (Monograph No. 54). Columbia, SC: University of South Carolina, National Resource Center for The First Year Experience and Students in Transition.

Rice, P.J. (2003). Adult student services office. In D. Kilgore, \& P. J. Rice (Eds.), Meeting the special needs of adult students (pp. 53-57). San Francisco, CA: Jossey-Bass. 
Ross-Gordon, J.M. (2003). Adult learners in the classroom. In D. Kilgore, \& P. J. Rice, P.J. (Eds.), Meeting the special needs of adult students (pp. 43-52). San Francisco, CA: Jossey-Bass.

Schwehm, J. S. (2017). Do student demographics and community college experiences influence the adjustment process of adult vertical transfer students? Community College Enterprise, 23(1), 9-25.

Scobey, D. (2016). Marginalized majority: Nontraditional students and the equity imperative Retrieved from Association of American Colleges \& Universities website: https://www.aacu.org/diversitydemocracy/2016/winter/scobey

Sherman, J., \& Andreas, M. (2012). The successful transfer structure in Washington State. In C. B. Kisker, \& R. L. Wagoner (Eds.), Implementing transfer associate degrees: Perspectives from the states (pp. 17-29). San Francisco, CA: Jossey-Bass.

Shugart, S. (2008). Adult Students: A priority revisited. Presidency, 11(1), 18-22.

Shugart, S.C., \& Harrison, D.T. (2011). Partnerships and student pathways. In M. A. Poisel \& S. Joseph (Eds.), Transfer students in higher education: Building foundations for policies, programs, and services that foster student success (Monograph No. 54, pp. 13-28). Columbia, SC: University of South Carolina, National Resource Center for the First Year Experience and Students in Transition.

Sissel, P. A., Hansman, C. A., \& Kasworm, C. E. (2002). The politics of neglect: Adult learners in higher education. New Directions for Adult and Continuing Education, 91, 17-28. doi: 10.1002/ace.27

Spellman, N. (2007). Enrollment and retention barriers adult students encounter. Community College Enterprise, 13(1), 63-79. 
Steele, P., \& Erisman, W. (2016). Addressing the college attainment gap for working adults with prior college credit. Change,48(2), 46-52.

Taylor, J. L., \& Jain, D. (2017). The multiple dimensions of transfer: Examining the transfer function in American higher education. Community College Review, 45(4), 273-293.

The Council for Adult and Experiential Learning. (2018). The growing importance of prior learning assessment in the degree-completion toolkit. Retrieved from http://cdn2.hubspot.net/hubfs/617695/Future-of-PLAArticle.pdf?submissionGuid=c1cb94ef-911d-41fd-8f49-4fc657bb9533

Thompson, C., \& Sheckley, B. G. (1997). Differences in classroom teaching preferences between traditional and adult BSN students. Journal of Nursing, 36, 163-170.

United States Census Bureau. (2018). Older people projected to outnumber children for the first Time in U.S. history. Retrieved from https://www.census.gov/newsroom/pressreleases/2018/cb18-41-population-projections.html

United States Department of Education. (2018). Fiscal Year 2018 budget summary and background information. Retrieved from https://www2.ed.gov/about/overview/budget/budget18/summary/18summary.pdf United States Department of Education. (2018, December). Rethinking higher education. Retrieved from https://www.insidehighered.com/sites/default/server_files/media/White\%20Paper\%20 on\%20Rethinking\%20Higher\%20Education\%2012.19.18.pdf

University of Illinois Springfield. (2018). Academics. Retrieved from https://www.uis.edu/academics/ 
Wlodarsky, R. (2018). A structured model for reflective adult learning among university faculty. Journal of Higher Education Theory \& Practice, 18(5), 98-111.

Yavitz, L.W. (2017). Vertical transfer and baccalaureate completion for adult community college students: Milestones and momentum points that matter. (Unpublished Doctoral dissertation). University of Nevada, Las Vegas.

Zamani, E. M. (2001). Institutional response to barriers to the transfer process. In F. S. Laanan, (Ed.), Transfer students: Trends and issues (pp. 15-24). San Francisco, CA: Jossey-Bass.

Zhang, Y.F., Lui, J., \& Hagedorn, L.S. (2013). Post transfer experiences: Adult undergraduate students at a research university. Journal of Applied Research in the Community College, 21(1), 31-40. 
APPENDIX A: DRAFT OF SURVEY INSTRUMENT 


\section{Draft of Survey Instrument}

Draft Questionnaire for Four-Year Institutions that was evaluated by Transfer Coordinators

1. What is the enrollment at your institution?
Less than 1,000
1,000 to 4,000
4,000 to 7,000
7,000 to 10,000
10,000 to 13,000
13,000 to 16,000
16,000 to 19,000
19,000 and above

2. Is your institution public or private?
Public
Private

3. What is the approximate number of transfer students who transfer to your university from a community college?
0 to 100 students
101 to 200 students
201 to 500 students
500 to 1,000 students
Over 1,000 students

4. To what extent is your institution dependent on the enrollment of students who are age 25 and older?

Very Dependent

1
3
Not Dependent 


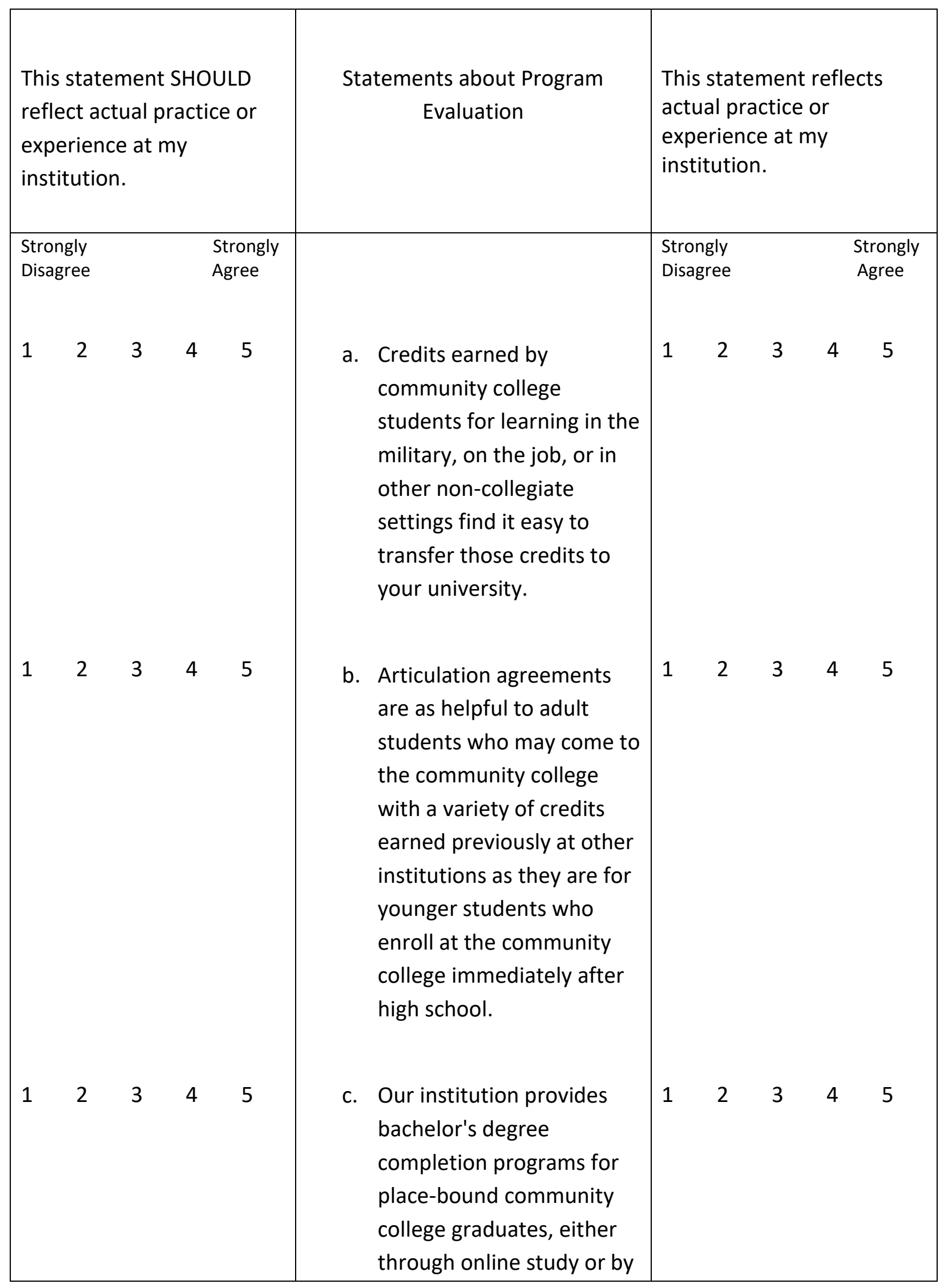




\begin{tabular}{|c|c|c|c|c|c|c|c|c|c|c|c|}
\hline \multicolumn{2}{|c|}{$\begin{array}{l}\text { Strongly } \\
\text { Disagree }\end{array}$} & \multicolumn{3}{|c|}{$\begin{array}{l}\text { Strongly } \\
\text { Agree }\end{array}$} & & $\begin{array}{l}\text { bringing upper-division } \\
\text { courses to the community } \\
\text { colleges. }\end{array}$ & \multicolumn{2}{|c|}{$\begin{array}{l}\text { Strongly } \\
\text { Disagree }\end{array}$} & & \multicolumn{2}{|c|}{$\begin{array}{l}\text { Strongly } \\
\text { Agree }\end{array}$} \\
\hline 1 & 2 & 3 & 4 & 5 & d. & $\begin{array}{l}\text { Articulation agreements } \\
\text { are in place to help } \\
\text { graduates of vocational } \\
\text { programs (i.e., Associate of } \\
\text { Applied Science graduates) } \\
\text { transfer to our institution. }\end{array}$ & 1 & 2 & 3 & 4 & 5 \\
\hline 1 & 2 & 3 & 4 & 5 & e. & $\begin{array}{l}\text { Orientation programs for } \\
\text { new transfer students at } \\
\text { our university are as } \\
\text { helpful to adult students in } \\
\text { making them feel welcome } \\
\text { and part of the } \\
\text { institutional culture as } \\
\text { they are for younger, } \\
\text { traditional students. }\end{array}$ & 1 & 2 & 3 & 4 & 5 \\
\hline 1 & 2 & 3 & 4 & 5 & f. & $\begin{array}{l}\text { Adult students transferring } \\
\text { to your institution from } \\
\text { community colleges feel as } \\
\text { welcome as younger } \\
\text { students transferring from } \\
\text { community colleges. }\end{array}$ & 1 & 2 & 3 & 4 & 5 \\
\hline 1 & 2 & 3 & 4 & 5 & g. & $\begin{array}{l}\text { Adult students transferring } \\
\text { to our institution have } \\
\text { opportunities to become } \\
\text { involved in campus life. }\end{array}$ & 1 & 2 & 3 & 4 & 5 \\
\hline
\end{tabular}




\begin{tabular}{|c|c|c|c|c|c|c|c|c|c|c|c|}
\hline 1 & 2 & 3 & 4 & 5 & & $\begin{array}{l}\text { Faculty at our institution } \\
\text { understand how teaching } \\
\text { adult learners may differ } \\
\text { from teaching younger, } \\
\text { traditional students. }\end{array}$ & 1 & 2 & 3 & 4 & 5 \\
\hline & & & & $\begin{array}{l}\text { rongly } \\
\text { gree }\end{array}$ & & & \multicolumn{3}{|c|}{$\begin{array}{l}\text { Strongly } \\
\text { Disagree }\end{array}$} & \multicolumn{2}{|c|}{$\begin{array}{l}\text { Strongly } \\
\text { Agree }\end{array}$} \\
\hline 1 & 2 & 3 & 4 & 5 & i. & $\begin{array}{l}\text { Our institution offers } \\
\text { courses at convenient } \\
\text { times and places that } \\
\text { accommodate students } \\
\text { with extensive job and } \\
\text { family obligations. }\end{array}$ & 1 & 2 & 3 & 4 & 5 \\
\hline 1 & 2 & 3 & 4 & 5 & $\mathrm{j}$. & $\begin{array}{l}\text { Our institution has a } \\
\text { general studies or } \\
\text { interdisciplinary bachelor's } \\
\text { degree program designed } \\
\text { specifically for adult } \\
\text { students. }\end{array}$ & 1 & 2 & 3 & 4 & 5 \\
\hline 1 & 2 & 3 & 4 & 5 & $\mathrm{k}$. & $\begin{array}{l}\text { Working with adult } \\
\text { students is a high priority } \\
\text { at our institution. }\end{array}$ & 1 & 2 & 3 & 4 & 5 \\
\hline 1 & 2 & 3 & 4 & 5 & I. & $\begin{array}{l}\text { Our institution reaches out } \\
\text { specifically to adult } \\
\text { students at community } \\
\text { colleges, informing them } \\
\text { of their opportunities to } \\
\text { transfer. }\end{array}$ & 1 & 2 & 3 & 4 & 5 \\
\hline
\end{tabular}




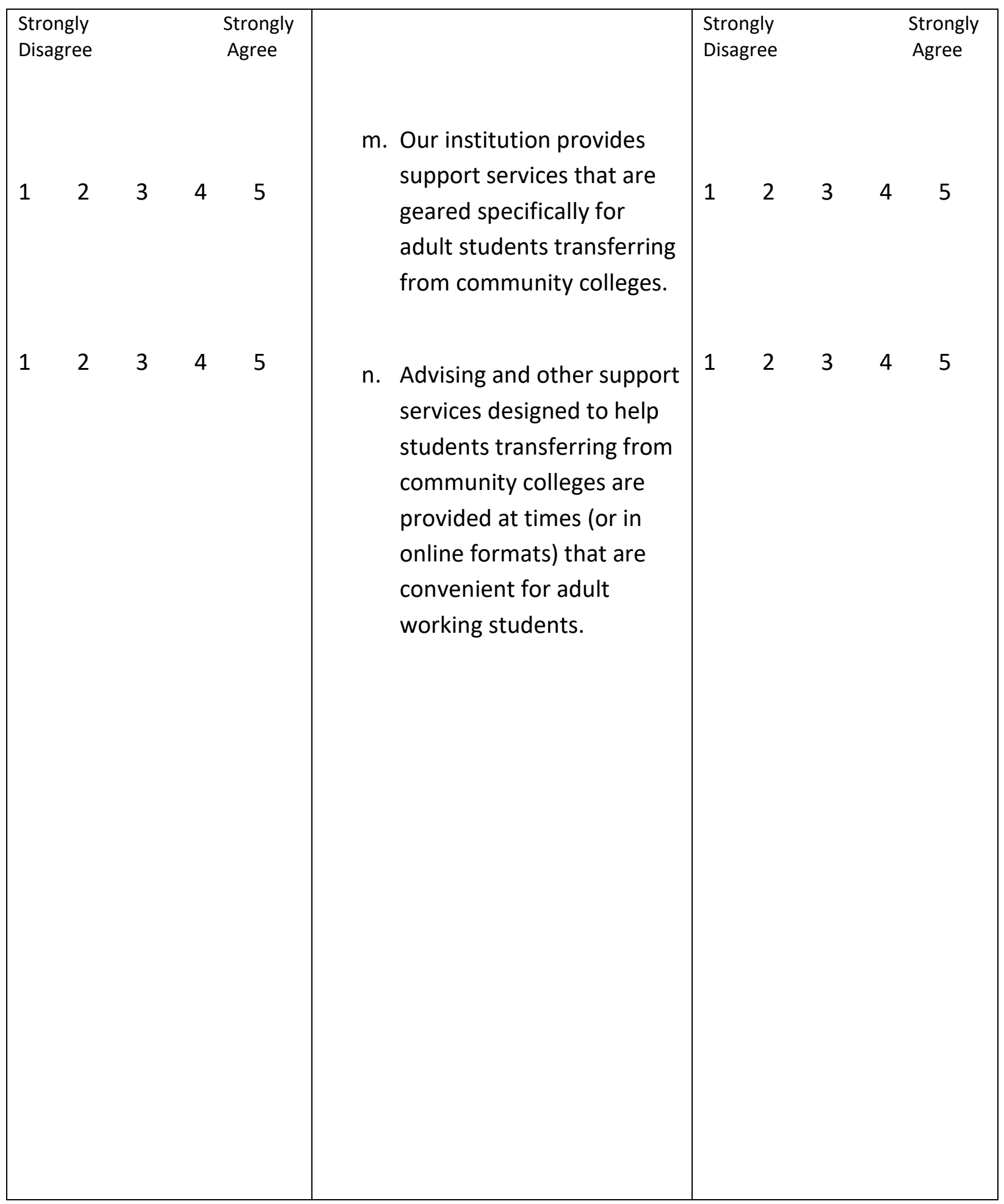




\section{Draft of Survey Instrument}

Draft Questionnaire for Community Colleges that was evaluated by Transfer Coordinators

1. What is your enrollment at your community college?
Less than 1,000
1,000 to 4,000
4,000 to 7,000
7,000 to 10,000
10,000 to 13,000
13,000 to 16,000
16,000 to 19,000
19,000 and above

2. What was the magnitude of transfer students who transferred from your community college to a university in the Fall 2014 semester?
0 to 100 students
101 to 200 students
201 to 500 students
500 to 1,000 students
Over 1,000 students

3. To what extent is your institution dependent on the enrollment of students who are age 25 and older?
Very Dependent
12
3
4
5
Not Dependent 


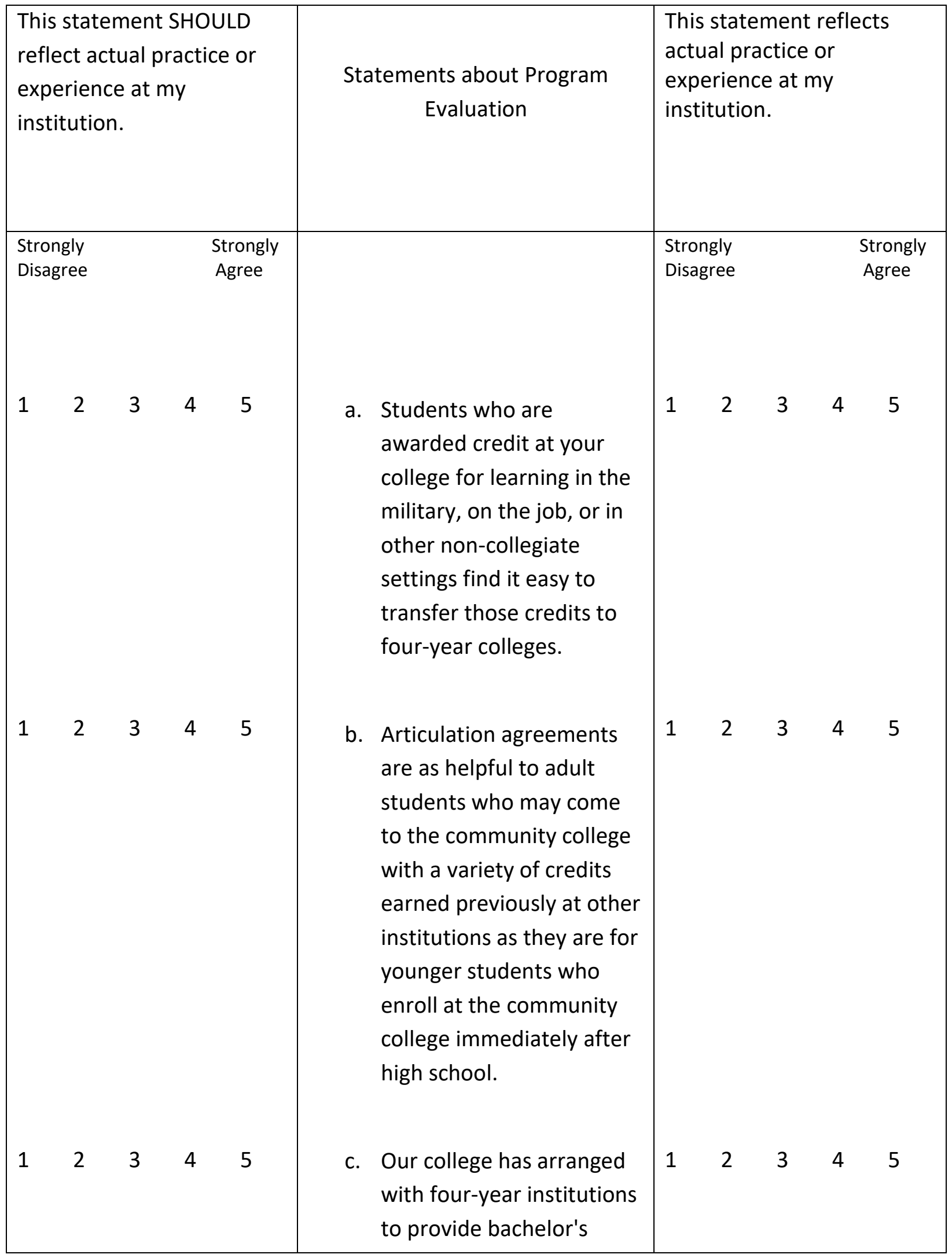




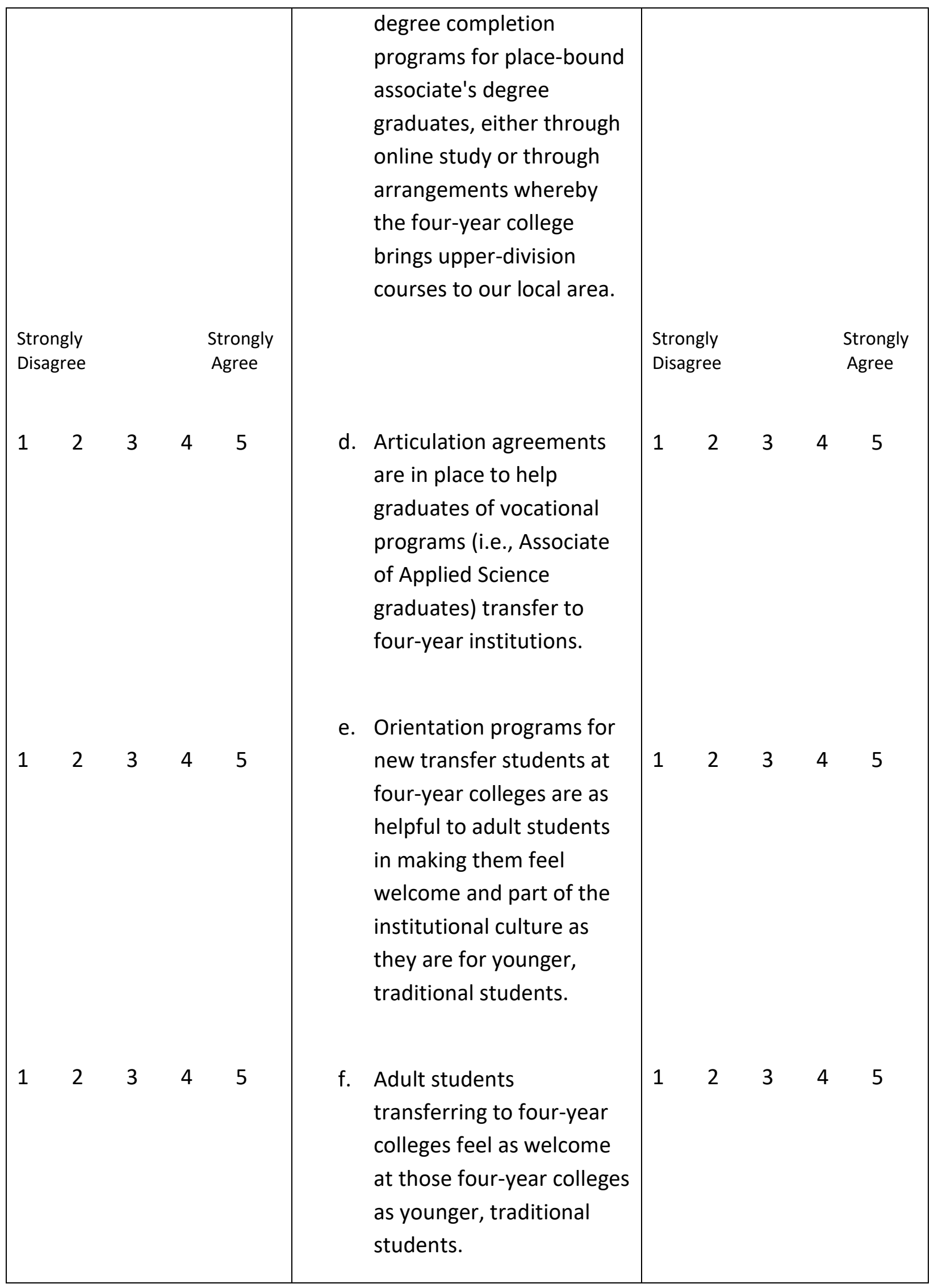




\begin{tabular}{|c|c|c|c|c|c|c|c|c|c|c|c|}
\hline & & & & $\begin{array}{l}\text { trongly } \\
\text { gree }\end{array}$ & & & & & & & $\begin{array}{l}\text { rongly } \\
\text { gree }\end{array}$ \\
\hline 1 & 2 & 3 & 4 & 5 & g. & $\begin{array}{l}\text { Adult students } \\
\text { transferring to four-year } \\
\text { colleges have } \\
\text { opportunities to become } \\
\text { involved in the campus life } \\
\text { of those institutions. }\end{array}$ & 1 & 2 & 3 & 4 & 5 \\
\hline 1 & 2 & 3 & 4 & 5 & & $\begin{array}{l}\text { Faculty at our institution } \\
\text { understand how teaching } \\
\text { adult learners may differ } \\
\text { from teaching younger, } \\
\text { traditional students. }\end{array}$ & 1 & 2 & 3 & 4 & 5 \\
\hline 1 & 2 & 3 & 4 & 5 & i. & $\begin{array}{l}\text { Our college offers courses } \\
\text { at convenient times and } \\
\text { places that accommodate } \\
\text { students with extensive } \\
\text { job and family obligations. }\end{array}$ & 1 & 2 & 3 & 4 & 5 \\
\hline 1 & 2 & 3 & 4 & 5 & & $\begin{array}{l}\text { Working with adult } \\
\text { students is a high priority } \\
\text { at our institution. }\end{array}$ & 1 & 2 & 3 & 4 & 5 \\
\hline 1 & 2 & 3 & 4 & 5 & k. & $\begin{array}{l}\text { Our institution makes } \\
\text { efforts to encourage adult } \\
\text { students to consider } \\
\text { transferring and working } \\
\text { towards a bachelor's } \\
\text { degree. }\end{array}$ & 1 & 2 & 3 & 4 & 5 \\
\hline 1 & 2 & 3 & 4 & 5 & I. & $\begin{array}{l}\text { Our institution provides } \\
\text { support services that are }\end{array}$ & 1 & 2 & 3 & 4 & 5 \\
\hline
\end{tabular}




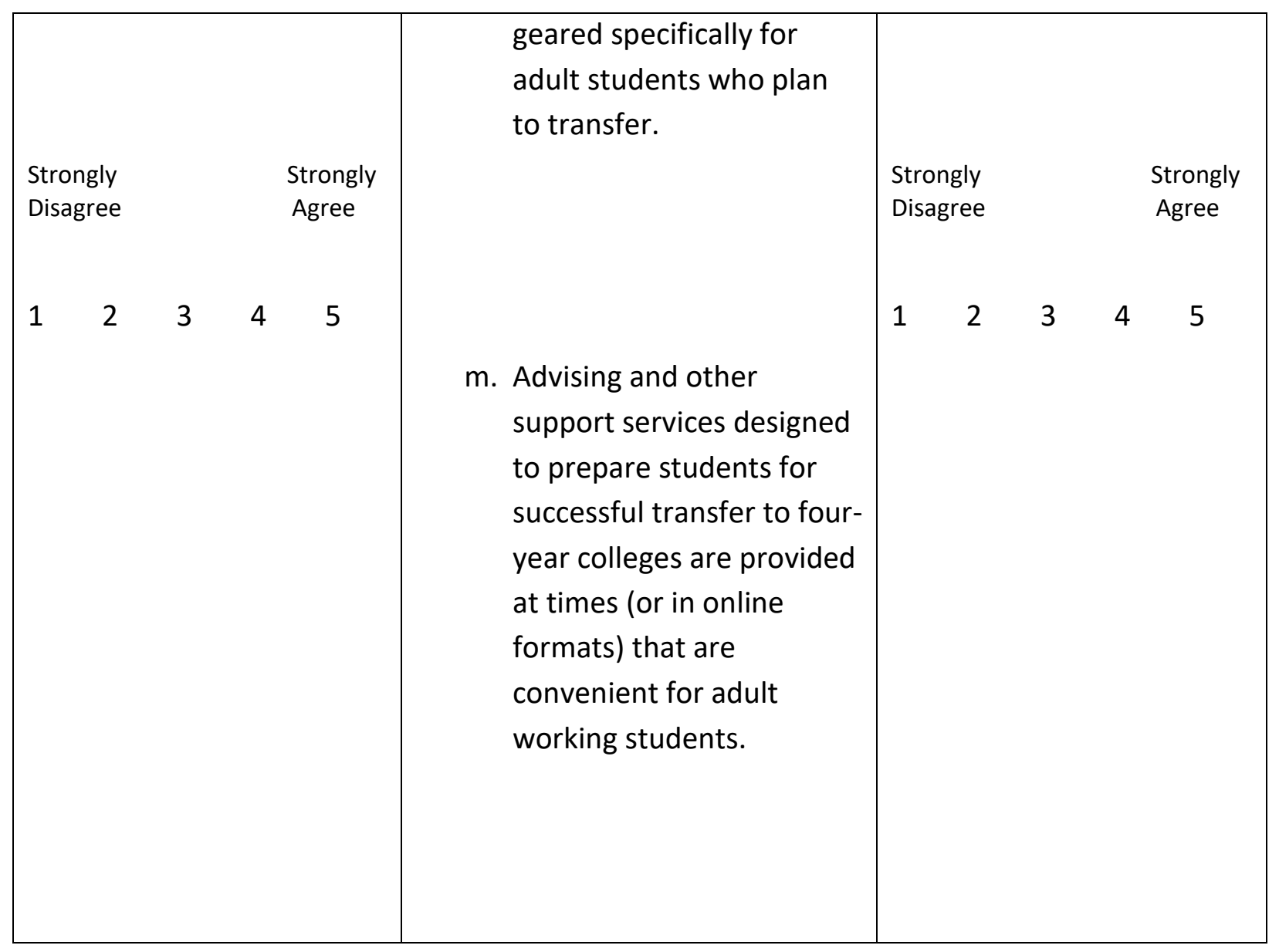


APPENDIX B: REVISED SURVEY INSTRUMENTS THAT INCORPORATE FOCUS GROUP FEEDBACK 
Revised Survey Instrument that incorporates Focus Group Feedback

\section{Questionnaire for Transfer Coordinators at Four-Year Institutions}

1. What is the enrollment at your institution?

$$
\begin{aligned}
& \text { Under } 1,000 \\
& 1,000 \text { to } 4,999 \\
& 5,000 \text { to } 9,999 \\
& 10,000 \text { to } 19,999 \\
& 20,000+
\end{aligned}
$$

2. Is your institution public or private?

$$
\begin{aligned}
& \text { Public } \\
& \text { Private }
\end{aligned}
$$

3. What is the approximate number of students who transfer to your institution from a community college?
0 to 100 students 101 to 200 students
201 to 500 students
500 to 1,000 students
Over 1,000 students
I don't know

4. What percentage of your institution's student enrollment is 25 years of age or older? 0 to 20 percent 21 to 40 percent 41 to 60 percent 61 to 80 percent 81 to 100 percent I don't know 


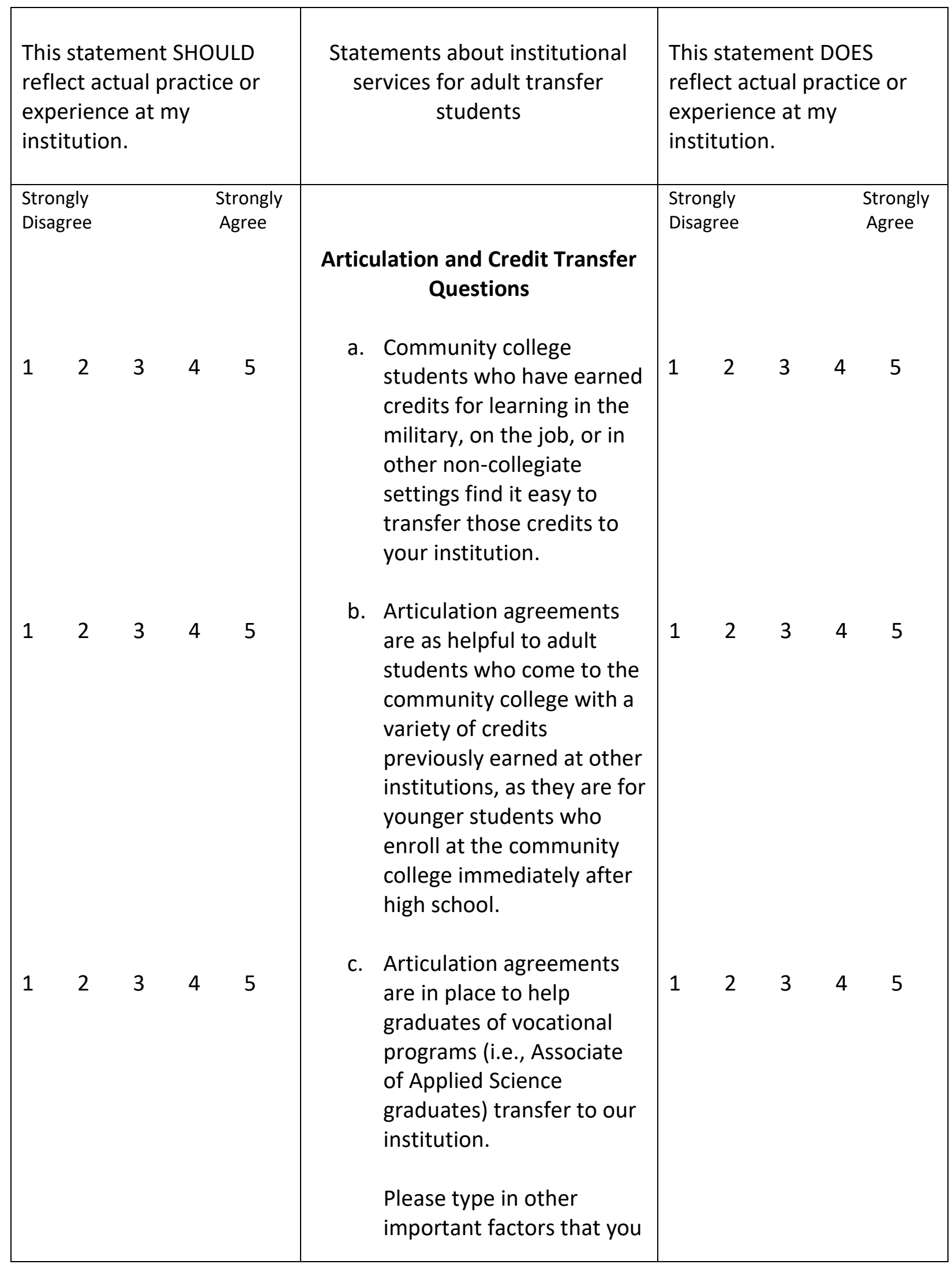




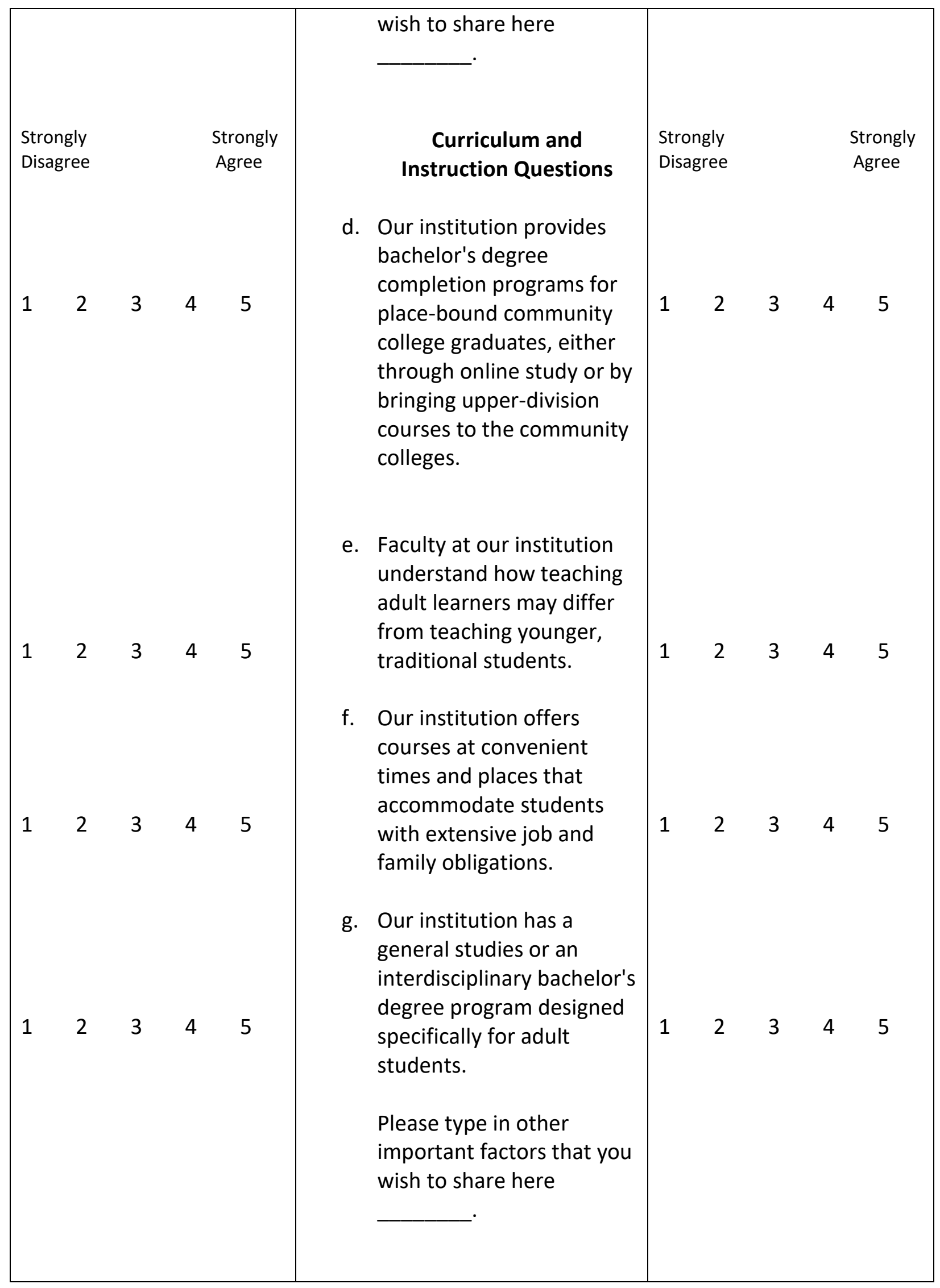




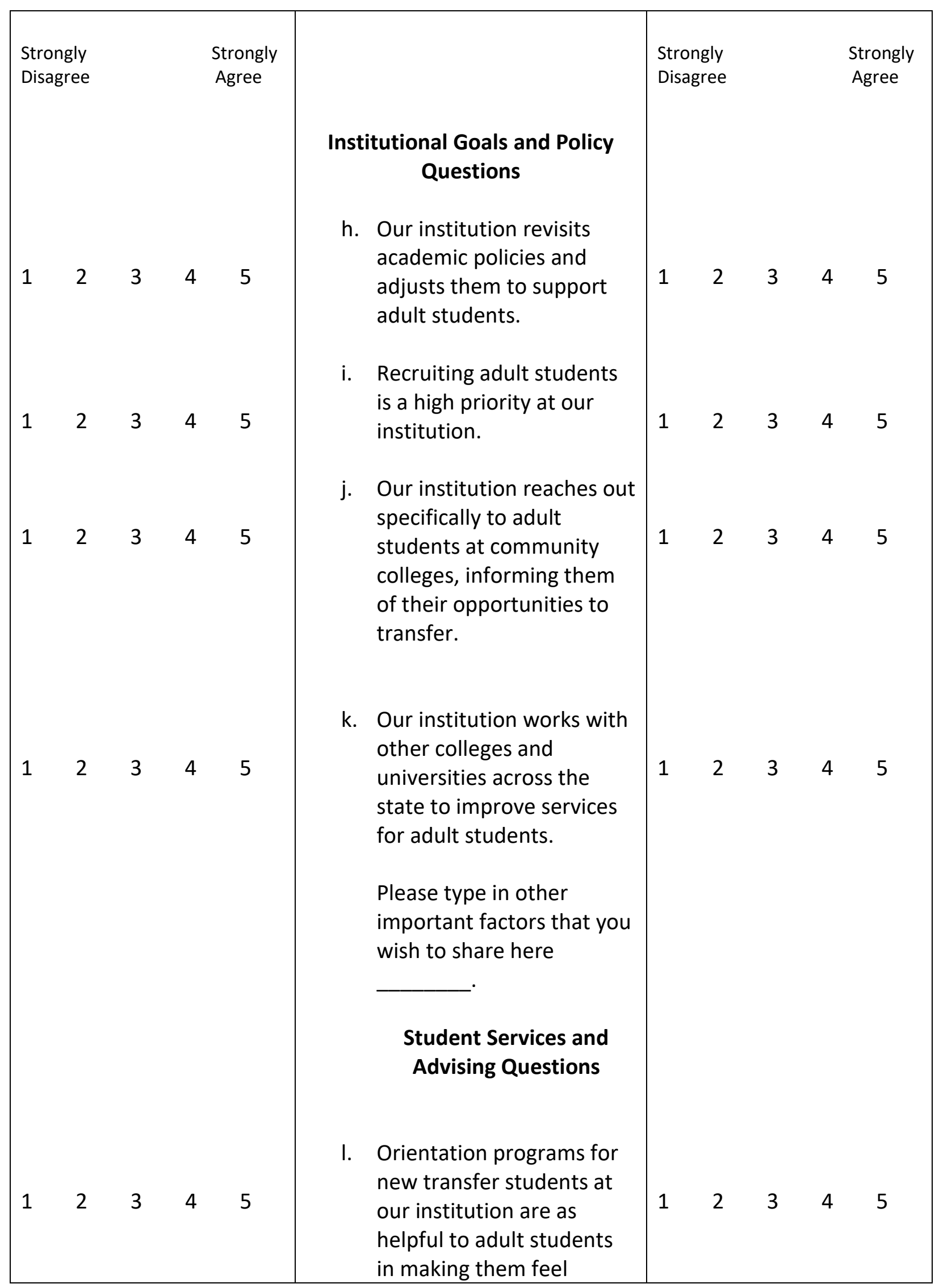




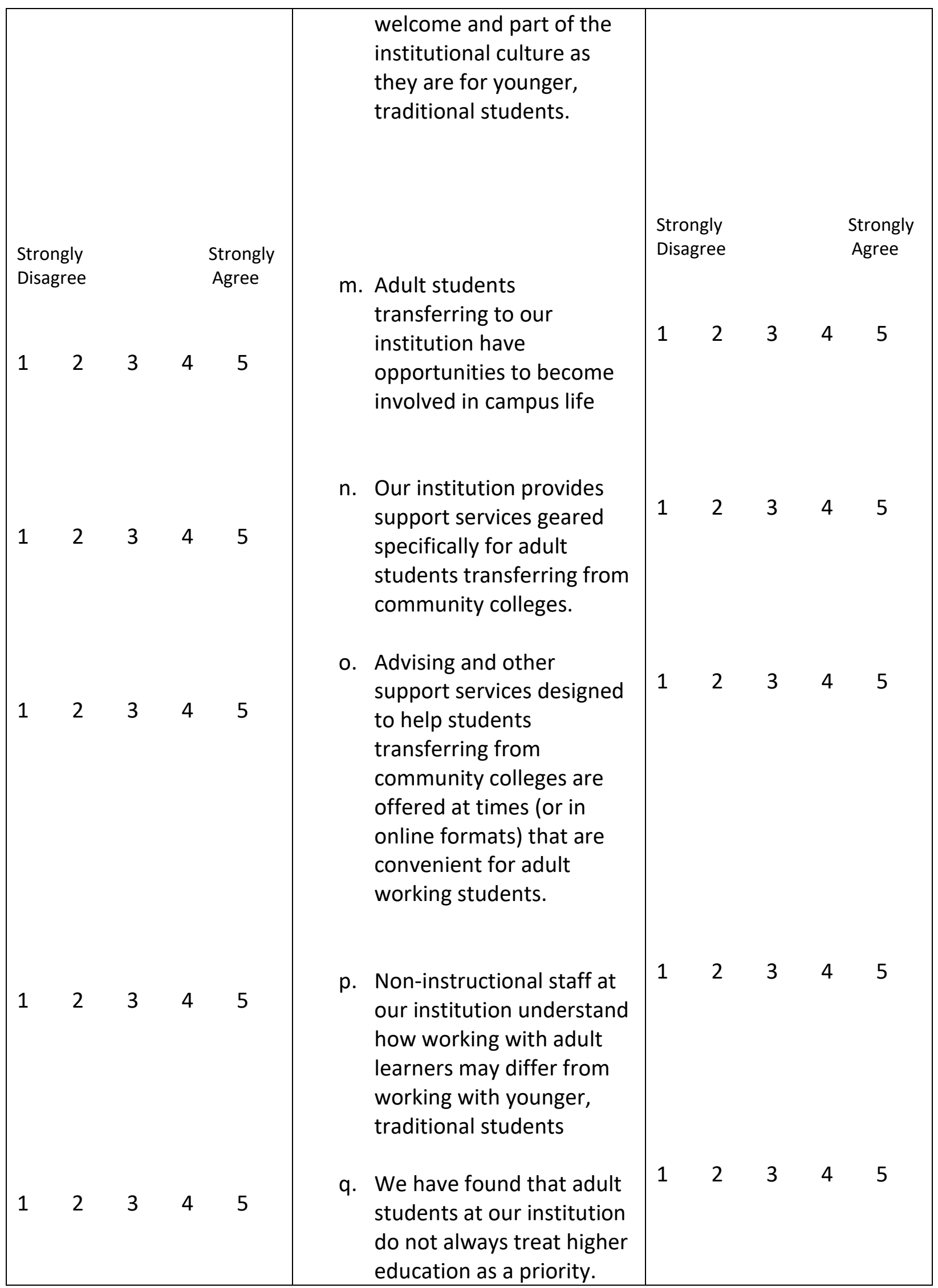




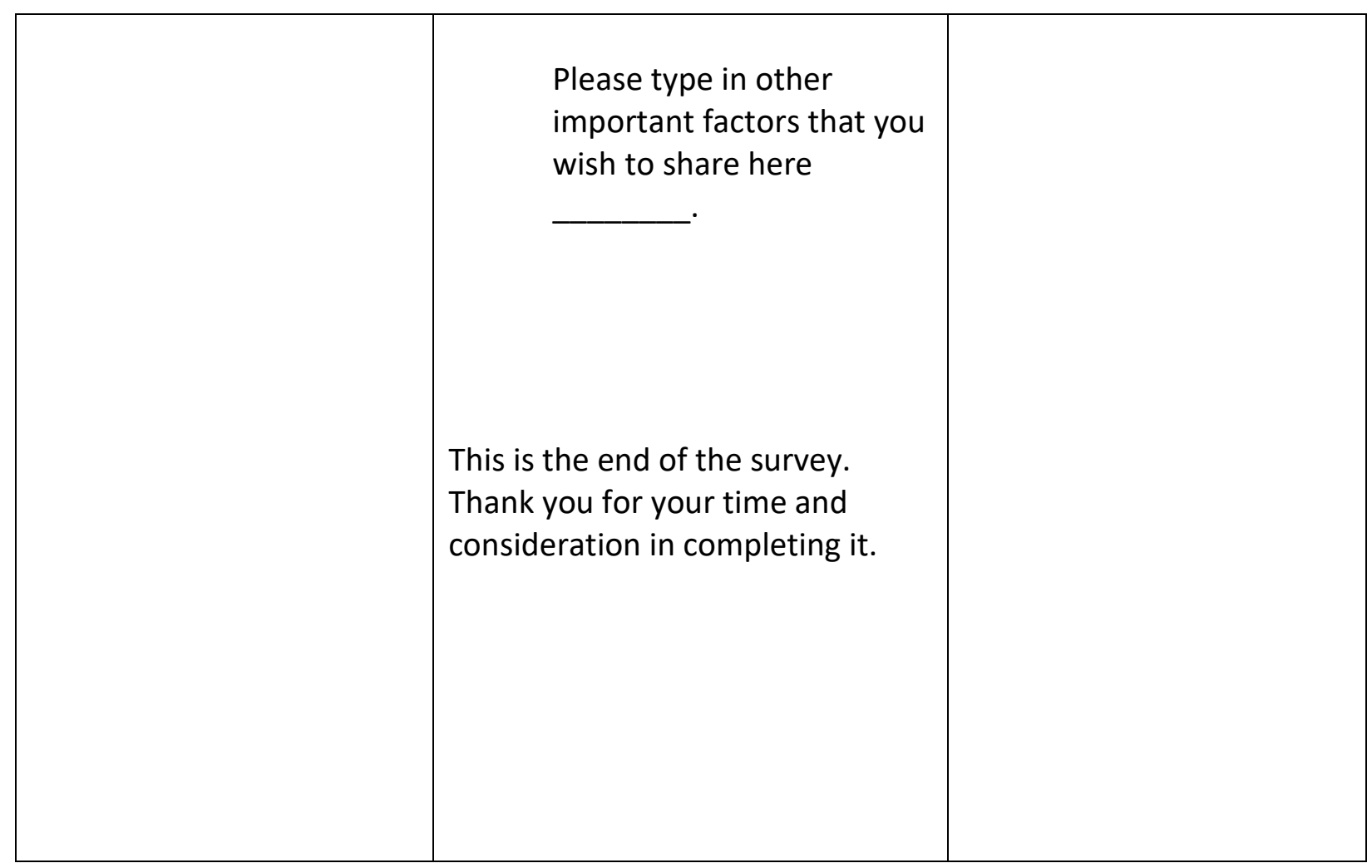


Revised Survey Instrument that incorporates Focus Group Feedback

Questionnaire for Transfer Coordinators at Community Colleges

1. What is your enrollment at your community college?
Under 1,000
1,000 to 4,999
5,000 to 9,999
10,000 to 19,999
$20,000+$

2. What was the magnitude of transfer students who transferred from your community college to a four-year institution in the Fall 2016 semester?
0 to 100 students
101 to 200 students
201 to 500 students
500 to 1,000 students
Over 1,000 students
I don't know

3. What percentage of your institution's student enrollment is 25 years of age or older?

0 to 20 percent

21 to 40 percent

41 to 60 percent

61 to 80 percent

81 to 100 percent

I don't know 


\begin{tabular}{|c|c|c|c|c|c|c|c|c|c|}
\hline \multicolumn{4}{|c|}{$\begin{array}{l}\text { This statement SHOULD } \\
\text { reflect actual practice or } \\
\text { experience at my } \\
\text { institution }\end{array}$} & $\begin{array}{c}\text { Statements about institutional } \\
\text { services for adult transfer students }\end{array}$ & \multicolumn{5}{|c|}{$\begin{array}{l}\text { This statement DOES } \\
\text { reflect actual practice or } \\
\text { experience at my } \\
\text { institution. }\end{array}$} \\
\hline $\begin{array}{l}\text { Strongly } \\
\text { Disagree }\end{array}$ & & & $\begin{array}{l}\text { trongly } \\
\text { Agree }\end{array}$ & $\begin{array}{c}\text { Articulation and Credit Transfer } \\
\text { Questions }\end{array}$ & & & & & Agree \\
\hline 12 & 3 & 4 & 5 & $\begin{array}{l}\text { a. Students who are awarded } \\
\text { credit at your college for } \\
\text { learning in the military, on } \\
\text { the job, or in other non- } \\
\text { collegiate settings find it } \\
\text { easy to transfer those } \\
\text { credits to four-year } \\
\text { institutions. }\end{array}$ & 1 & 2 & 3 & 4 & 5 \\
\hline 12 & 3 & 4 & 5 & $\begin{array}{l}\text { b. Articulation agreements } \\
\text { are as helpful to adult } \\
\text { students who may come to } \\
\text { the community college } \\
\text { with a variety of credits } \\
\text { earned previously at other } \\
\text { institutions as they are for } \\
\text { younger students who } \\
\text { enroll at the community } \\
\text { college immediately after } \\
\text { high school. }\end{array}$ & 1 & 2 & 3 & 4 & 5 \\
\hline 2 & 3 & 4 & 5 & $\begin{array}{l}\text { c. Articulation agreements } \\
\text { are in place to help } \\
\text { graduates of vocational } \\
\text { programs (i.e., Associate of } \\
\text { Applied Science graduates) } \\
\text { transfer to four-year } \\
\text { institutions. } \\
\text { Please type in other } \\
\text { important factors that you } \\
\text { wish to share here }\end{array}$ & 1 & 2 & 3 & 4 & 5 \\
\hline
\end{tabular}




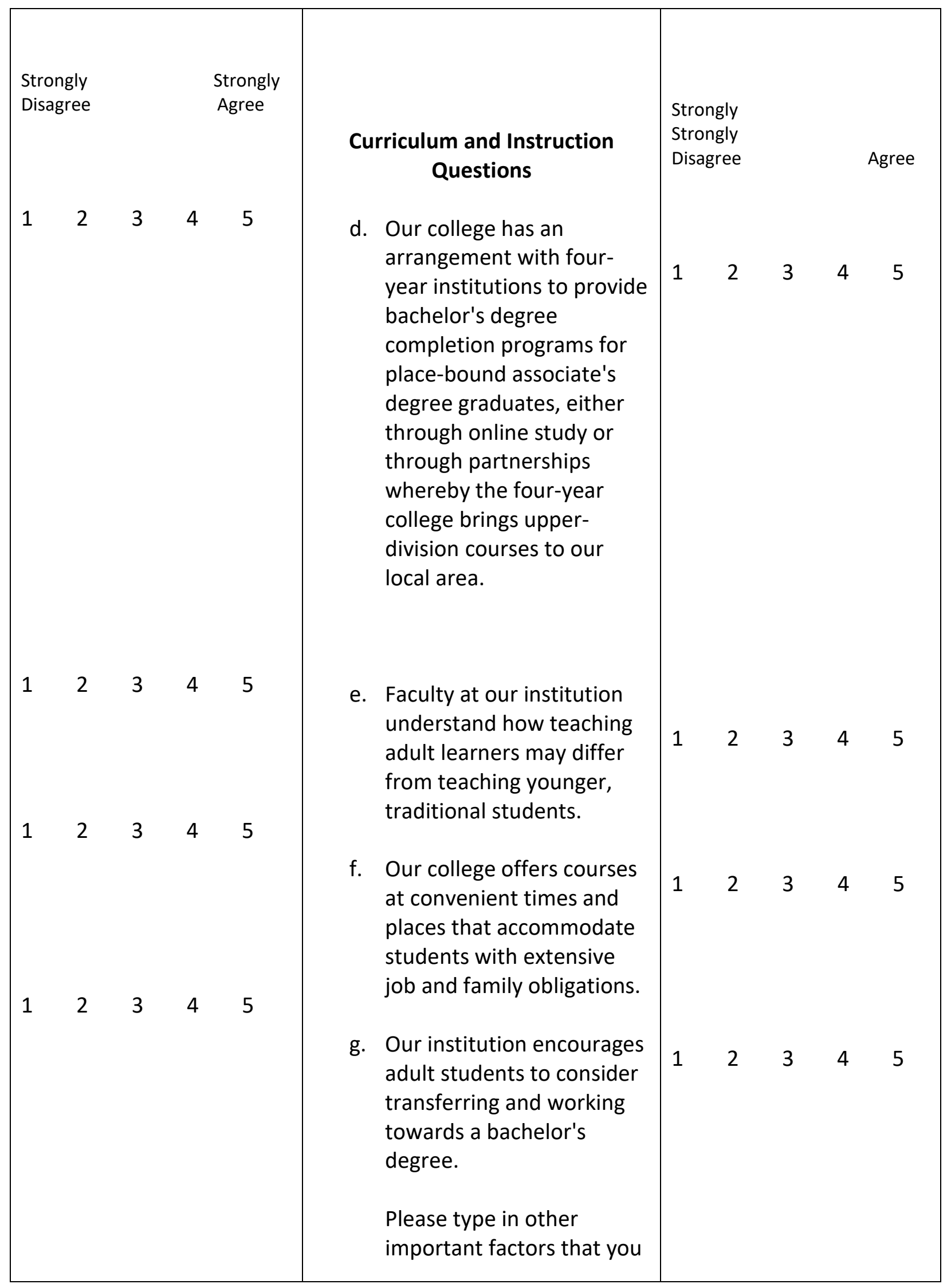




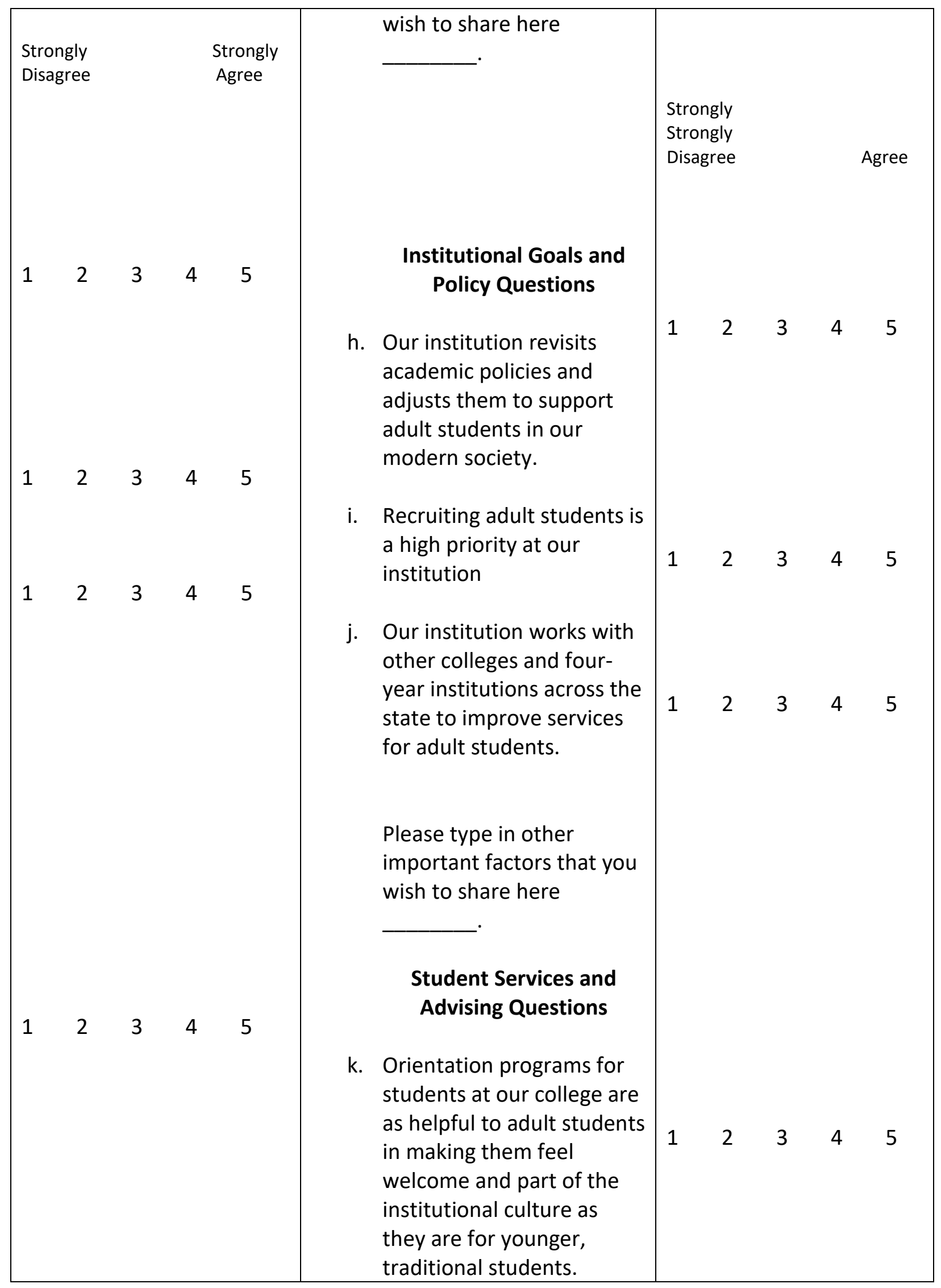




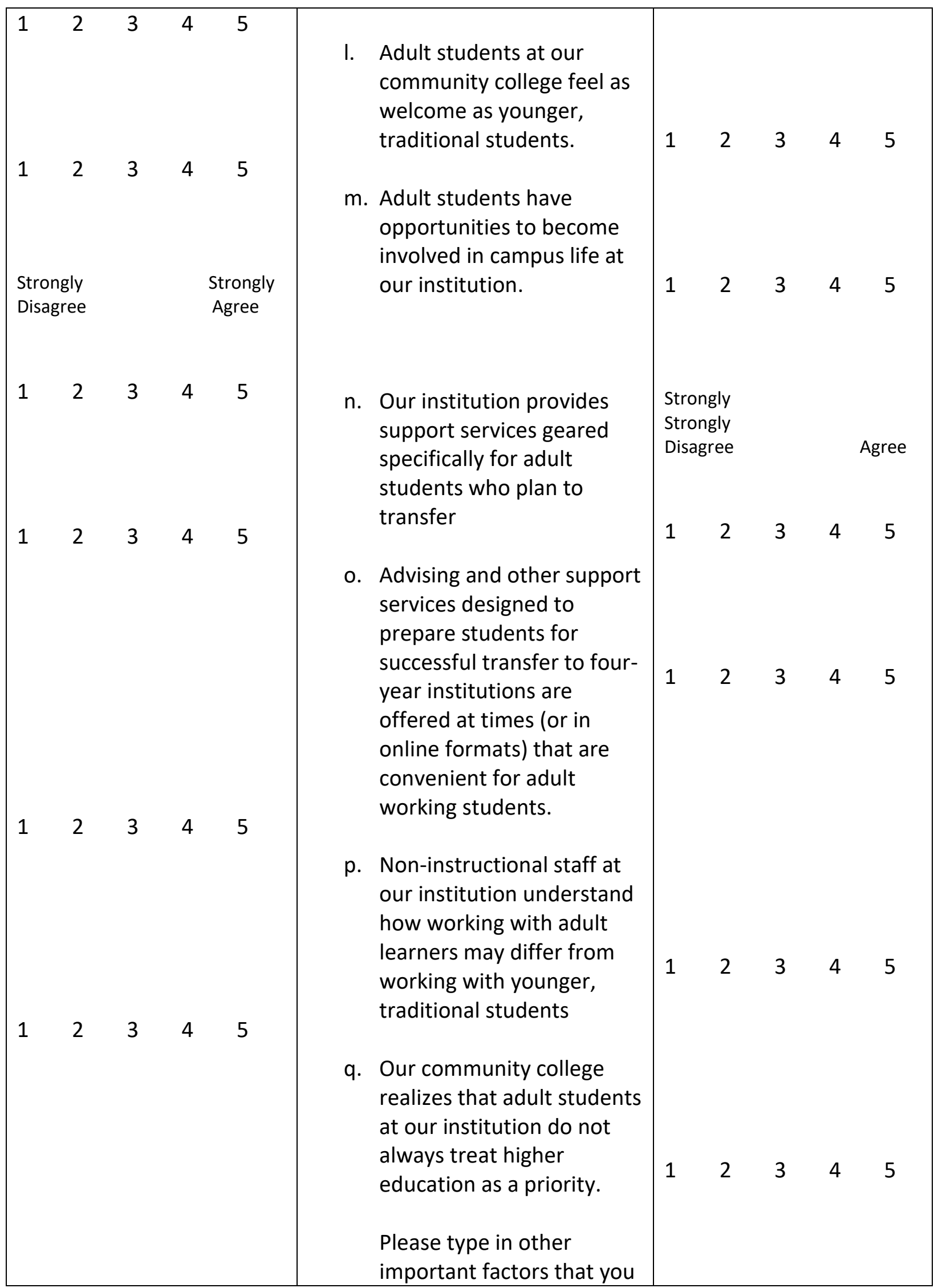




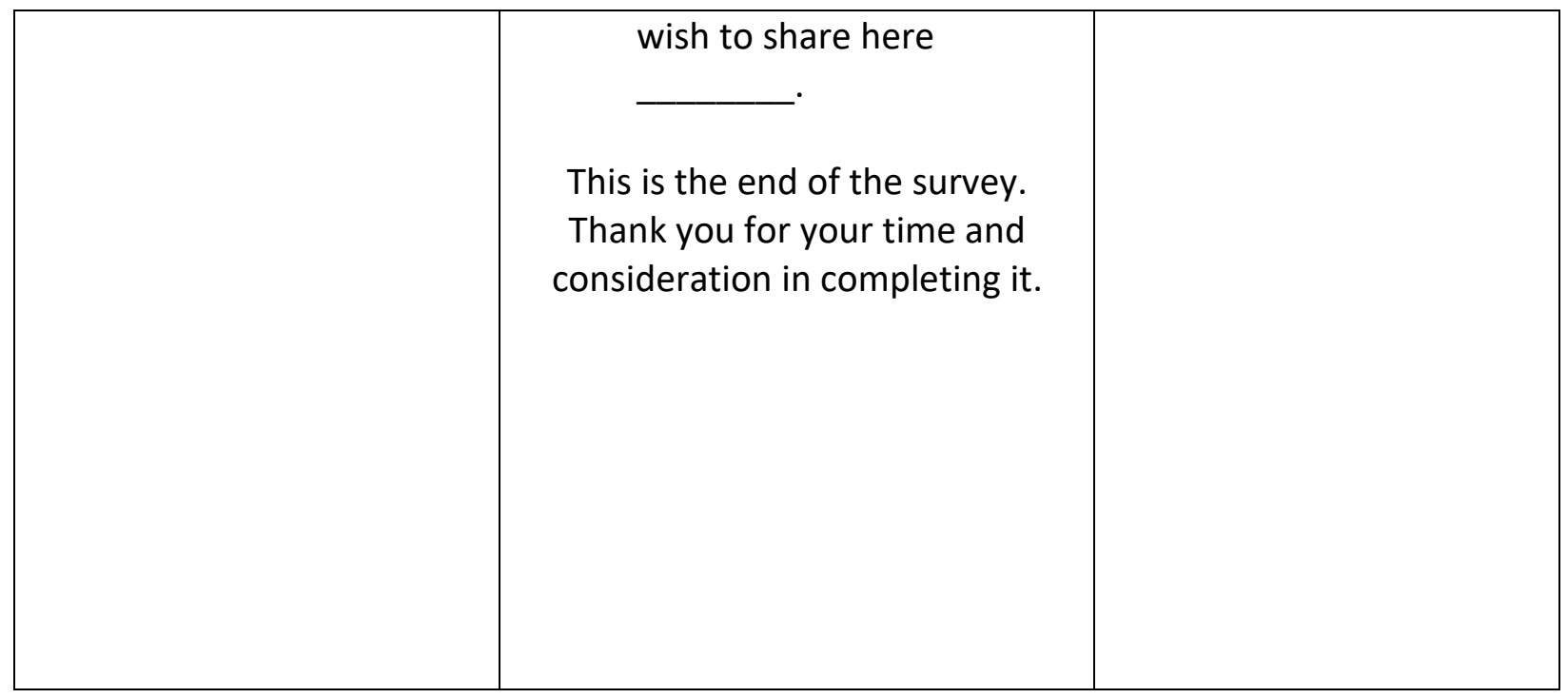


APPENDIX C: LETTERS AND STUDY REFERENCE GUIDES FOR FOUR-YEAR INSTITUTION AND COMMUNITY COLLEGE PARTICIPANTS 
Letter Sent to Four-Year Institution Survey Participants

Dear Transfer Coordinator,

Adult students, those over 25 with significant family and job obligations, constitute a growing undergraduate population. Many begin at community colleges and transfer to universities. Little attention, however, has been given to the services and programs that might assist these students in the transfer process. That is why I am asking for your participation in a study designed to elicit the perceptions of transfer coordinators concerning the services that are and should be provided for adult students making the transition from community colleges to fouryear institutions. Results will be published in a Ph.D. dissertation I am preparing for Illinois State University.

More specifically, I am requesting that you complete an online survey eliciting your perceptions of what is being done at your institution to help adult students transfer from community colleges to four-year institutions and what should be done. A detailed overview of the study's purpose and procedures, as well as of risks and benefits, is provided in the enclosed reference guide.

The questionnaire, which will take approximately 20-30 minutes to complete, can be accessed at:

https://www.surveymonkey.com/r/fouins

You were selected as a potential participant in this study because you are listed as a transfer coordinator for your institution on the iTransfer website:

https://itransfer.org/transfercoordinators/transfercoorddirectory.php

Your insights will greatly add to our understanding of how community colleges and universities work with adult students to transfer. In addition, although the study will yield few direct benefits to you personally, I hope you will find that the opportunity to reflect on your work is personally rewarding and helpful as you continue to be the transfer coordinator at Benedictine University. Only aggregate survey results will be published in the dissertation, and the names of your college or university will not be identified.

Thank you for your consideration of this request. Please feel free to contact me with any questions. You can also contact my dissertation advisor, Dr. Jim Palmer (xxxxxx@xxxxxxx). Should you have questions about your rights as a study participant and the steps undertaken to minimize the risks you will face as a participant, please feel free to contact the Research Ethics and Compliance Office at Illinois State University (309.438.2529).

Sincerely,

Bethany Craig

Doctoral Candidate

Educational Administration and Foundations 
Illinois State University

Letter Sent to Community College Survey Participants

Dear Transfer Coordinator,

Adult students, those over 25 with significant family and job obligations, constitute a growing undergraduate population. Many begin at community colleges and transfer to universities. Little attention, however, has been given to the services and programs that might assist these students in the transfer process. That is why I am asking for your participation in a study designed to elicit the perceptions of transfer coordinators concerning the services that are and should be provided for adult students making the transition from community colleges to fouryear institutions. Results will be published in a Ph.D. dissertation I am preparing for Illinois State University.

More specifically, I am requesting that you complete an online survey eliciting your perceptions of what is being done at your institution to help adult students transfer from community colleges to four-year institutions and what should be done. A detailed overview of the study's purpose and procedures, as well as of risks and benefits, is provided in the enclosed reference guide.

The questionnaire, which will take approximately 20-30 minutes to complete, can be accessed at:

\section{https://www.surveymonkey.com/r/comcol}

You were selected as a potential participant in this study because you are listed as a transfer coordinator for your institution on the iTransfer website:

https://itransfer.org/transfercoordinators/transfercoorddirectory.php

Your insights will greatly add to our understanding of how community colleges and universities work with adult students to transfer. In addition, although the study will yield few direct benefits to you personally, I hope you will find that the opportunity to reflect on your work is personally rewarding and helpful as you continue to be the transfer coordinator at Illinois Valley Community College. Only aggregate survey results will be published in the dissertation, and the names of your college or university will not be identified.

Thank you for your consideration of this request. Please feel free to contact me with any questions. You can also contact my dissertation advisor, Dr. Jim Palmer (xxxxxxx@xxxxxxx). Should you have questions about your rights as a study participant and the steps undertaken to minimize the risks you will face as a participant, please feel free to contact the Research Ethics and Compliance Office at Illinois State University (309.438.2529).

Sincerely,

Bethany Craig

Doctoral Candidate

Educational Administration and Foundations 
Illinois State University

Study Reference Guide for Four-Year Institution Survey Participants

Purpose of the study. The online survey I am asking you to complete is part of a study eliciting the perceptions of transfer coordinators concerning (a) what their institutions are currently doing to help adult students in the transfer process, (b) what their institutions should be doing, and (c) what gap, if any, exists between actual practice and desired practice.

Study procedures. Should you decide to participate, I will ask you to complete a survey that is available at:

https://www.surveymonkey.com/r/fouins

The survey will take 20-30 minutes to complete. It has two parts.

Part 1 poses four questions about your institution in terms of overall enrollment, control (private or public), the approximate number of students who transfer to your institution [in the case of 4-year institutions] or from your institution [in the case of community colleges], and the extent to which your institution is dependent on the enrollment of students who are 25 or older.

Part 2 provides a series of statements that relate to the transfer of adult students from community colleges to four-year institutions. For each statement, you will be asked (on 1-5 scales) to rate your agreement concerning (a) the extent to which the statement DOES reflect actual practice at your institution and (b) the extent to which the statement SHOULD reflect actual practice at your institution.

How you were selected for participation. I am inviting transfer coordinators from Illinois community colleges and universities to participate in the study. You were selected as a potential participant in this study because you are listed as a transfer coordinator on the iTransfer website: https://itransfer.org/transfercoordinators/transfercoorddirectory.php.

Voluntary participation. Participation in this study is entirely voluntary. If you choose not to participate or would like to withdraw from the study at any time, there will be no penalty of any kind. You may also decline to answer any question you are uncomfortable with.

Risks. The main risk in this research study is breach of confidentiality. Each participant has the right to expect that their comments will remain confidential. Although the intent is to develop an aggregate picture of the services and programs that community colleges and universities currently use and can use to help adult students transfer successfully, data from individual respondents might be inappropriately used to judge the services and programs at individual institutions.

Steps that will be taken to minimize risks. In addition to reporting aggregate results only, important steps will be taken to minimize the risk of a breach of confidentiality: 
- Data will be collected via the SurveyMonkey online service at www.surveymonkey.com. Only Bethany Craig and her dissertation adviser at Illinois State University (Dr. Jim Palmer) will have access to survey responses typed in by study subjects at this site.

- The Survey Monkey Secure Sockets Layer (SSL) encryption feature will be enabled. See: http://help.surveymonkey.com/articles/en_US/kb/What-is-the-enhanced-security-optionSSL-encryption

- In addition, IP addresses will be masked and not associated with responses. See http://help.surveymonkey.com/articles/en US/kb/How-do-I-turn-off-the-IP-addressescollection-on-the-responses

- The survey does not ask for your name or for the name of your institution

- Raw data will be downloaded from the Survey Monkey site and stored on Bethany Craig's password-protected PC at her home at 1530 Harrison Avenue La Grange Park, IL 60526. This data will not be stored or transmitted to any additional devices. Only Dr. Palmer and Bethany Craig will have access to these raw data.

- The raw data in the Survey Monkey account and in the computers owned by Craig and Palmer will be erased after the dissertation is completed and filed with Illinois State University.

Benefits. The study will enhance our understanding of (a) the practices used by community colleges and universities to help adult students transfer successfully from the community college to the university, (b) the gap, if any, between the practices and measures that are used and the practices and measures that, in the opinion of transfer coordinators, should be used, and $(c)$ the implications for practice. You may also find that completing the questionnaire helps you think through your own efforts to help adult students.

Further Information. Please feel free to contact Bethany Craig (xxxxxxx@xxxxxxx) with any questions. You can also contact my dissertation advisor, Dr. Jim Palmer (xxxxxxx@xxxxxxx). Should you have questions about your rights as a study participant and the steps undertaken to minimize the risks you will face as a participant, please feel free to contact the Research Ethics and Compliance Office at Illinois State University (309.438.2529). 


\section{Study Reference Guide for Community College Survey Participants}

Purpose of the study. The online survey I am asking you to complete is part of a study eliciting the perceptions of transfer coordinators concerning (a) what their institutions are currently doing to help adult students in the transfer process, (b) what their institutions should be doing, and (c) what gap, if any, exists between actual practice and desired practice.

Study procedures. Should you decide to participate, I will ask you to complete a survey that is available at:

$$
\text { https://www.surveymonkey.com/r/comcol }
$$

The survey will take 20-30 minutes to complete. It has two parts.

Part 1 poses four questions about your institution in terms of overall enrollment, control (private or public), the approximate number of students who transfer to your institution [in the case of 4-year institutions] or from your institution [in the case of community colleges], and the extent to which your institution is dependent on the enrollment of students who are 25 or older.

Part 2 provides a series of statements that relate to the transfer of adult students from community colleges to four-year institutions. For each statement, you will be asked (on 1-5 scales) to rate your agreement concerning (a) the extent to which the statement DOES reflect actual practice at your institution and (b) the extent to which the statement SHOULD reflect actual practice at your institution.

How you were selected for participation. I am inviting transfer coordinators from Illinois community colleges and universities to participate in the study. You were selected as a potential participant in this study because you are listed as a transfer coordinator on the iTransfer website: https://itransfer.org/transfercoordinators/transfercoorddirectory.php

Voluntary participation. Participation in this study is entirely voluntary. If you choose not to participate or would like to withdraw from the study at any time, there will be no penalty of any kind. You may also decline to answer any question you are uncomfortable with.

Risks. The main risk in this research study is breach of confidentiality. Each participant has the right to expect that their comments will remain confidential. Although the intent is to develop an aggregate picture of the services and programs that community colleges and universities currently use and can use to help adult students transfer successfully, data from individual respondents might be inappropriately used to judge the services and programs at individual institutions.

Steps that will be taken to minimize risks. In addition to reporting aggregate results only, important steps will be taken to minimize the risk of a breach of confidentiality: 
- Data will be collected via the SurveyMonkey online service at www.surveymonkey.com. Only Bethany Craig and her dissertation adviser at Illinois State University (Dr. Jim Palmer) will have access to survey responses typed in by study subjects at this site.

- The Survey Monkey Secure Sockets Layer (SSL) encryption feature will be enabled. See: http://help.surveymonkey.com/articles/en_US/kb/What-is-the-enhanced-security-optionSSL-encryption

- In addition, IP addresses will be masked and not associated with responses. See http://help.surveymonkey.com/articles/en US/kb/How-do-I-turn-off-the-IP-addressescollection-on-the-responses

- The survey does not ask for your name or for the name of your institution

- Raw data will be downloaded from the Survey Monkey site and stored on Bethany Craig's password-protected PC at her home at 1530 Harrison Avenue La Grange Park, IL 60526. This data will not be stored or transmitted to any additional devices. Only Dr. Palmer and Bethany Craig will have access to these raw data.

- The raw data in the Survey Monkey account and in the computers owned by Craig and Palmer will be erased after the dissertation is completed and filed with Illinois State University.

Benefits. The study will enhance our understanding of (a) the practices used by community colleges and universities to help adult students transfer successfully from the community college to the university, (b) the gap, if any, between the practices and measures that are used and the practices and measures that, in the opinion of transfer coordinators, should be used, and (c) the implications for practice. You may also find that completing the questionnaire helps you think through your own efforts to help adult students.

Further Information. Please feel free to contact Bethany Craig (xxxxxxx@xxxxxxx) with any questions. You can also contact my dissertation advisor, Dr. Jim Palmer (xxxxxxx@xxxxxxx). Should you have questions about your rights as a study participant and the steps undertaken to minimize the risks you will face as a participant, please feel free to contact the Research Ethics and Compliance Office at Illinois State University (309.438.2529). 